\title{
FERNANDO GARBELOTTI
}

Expressão do mRNA do VEGF, FIt-1 e KDR no

placentoma, região interplacentomal e corpo lúteo em diferentes fases gestacionais em bovinos clonados e não clonados

São Paulo 


\section{FERNANDO GARBELOTTI}

\section{Expressão do mRNA do VEGF, Flt-1 e KDR no placentoma, região interplacentomal e corpo lúteo em diferentes fases gestacionais em bovinos clonados e não clonados}

Dissertação apresentada ao Programa de Pós-graduação em Anatomia dos Animais Domésticos e Silvestres da Faculdade de Medicina Veterinária e Zootecnia da Universidade de São Paulo para obtenção do título de Mestre em Ciências

\section{Departamento:}

Cirurgia

Área de Concentração:

Anatomia dos Animais Domésticos e Silvestres

Orientador:

Profa. Dra. Paula de Carvalho Papa

\section{São Paulo}


Autorizo a reprodução parcial ou total desta obra, para fins acadêmicos, desde que citada a fonte.

DADOS INTERNACIONAIS DE CATALOGAÇÃO-NA-PUBLICAÇÃO

(Biblioteca Virginie Buff D’Ápice da Faculdade de Medicina Veterinária e Zootecnia da Universidade de São Paulo)

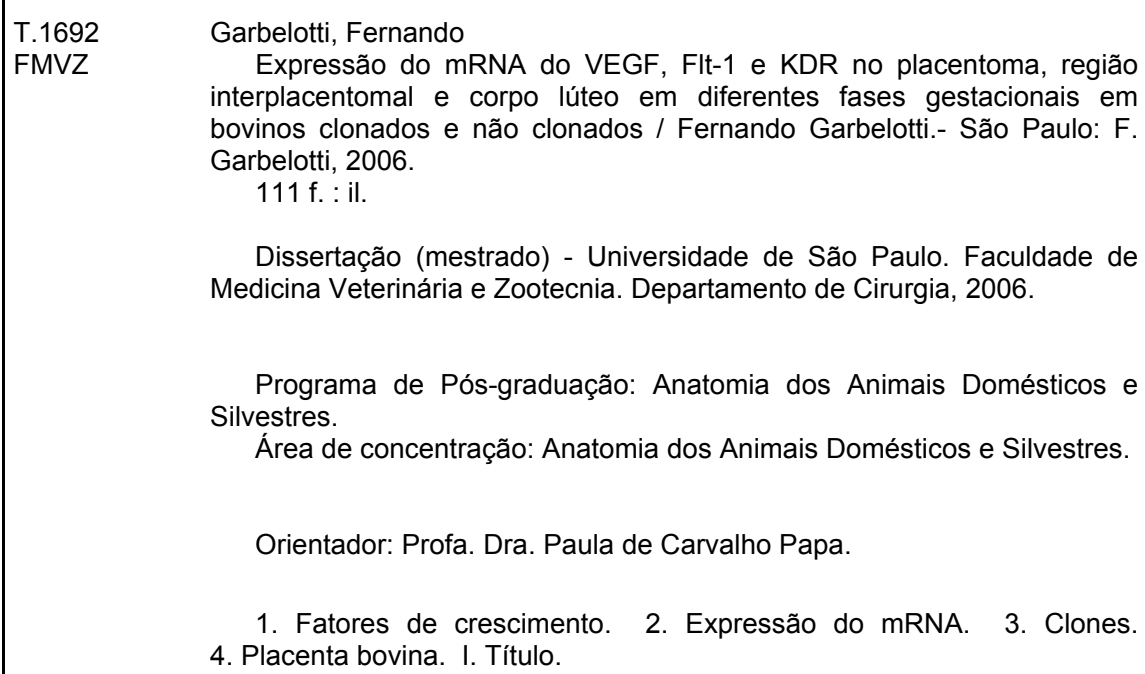

Dissertação (mestrado) - Universidade de São Paulo. Faculdade de Medicina Veterinária e Zootecnia. Departamento de Cirurgia, 2006.

Programa de Pós-graduação: Anatomia dos Animais Domésticos e Silvestres.

Área de concentração: Anatomia dos Animais Domésticos e Silvestres.

Orientador: Profa. Dra. Paula de Carvalho Papa.

1. Fatores de crescimento. 2. Expressão do mRNA. 3. Clones. 4. Placenta bovina. I. Título. 


\section{UNIVERSIDADE DE SÃO PAULO \\ Faculdade de Medicina Veterinária e Zootecnia \\ Comissão de Bioética}

\section{$P A R E C E R$}

Interessado: Fernando Garbelotti

Assunto: Protocolo de experimentação adotado em experimento animal.

A Comissão de Bioética da Faculdade de Medicina Veterinária e Zootecnia da Universidade de São Paulo, após analisar o projeto sob o número 792/2005, intitulado: "Expressão do RNAm do VEGF e seus receptores na placenta bovina de animais clonados e não clonados", utilizando 22 placentônios de vaca, sob responsabilidade da Profa. Dra. Paula de Carvalho Papa, constatou que o mesmo foi realizado de acordo com os princípios de bioética, adotados por esta Comissão.

São Paulo, 09 de novembro de 2005

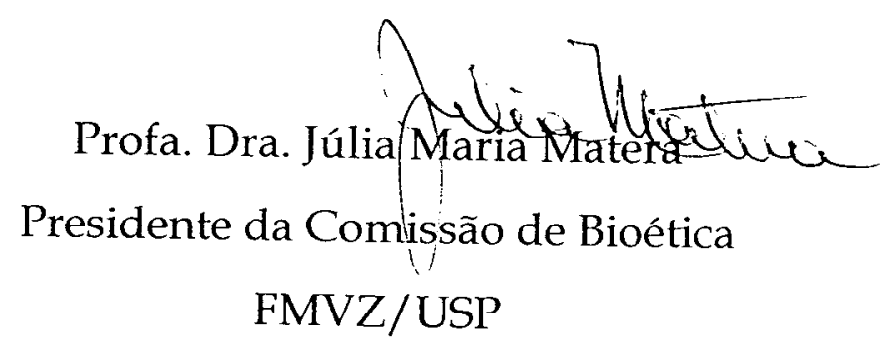




\section{FOLHA DE APROVAÇÃO}

Nome: GARBELOTTI, Fernando

Título: Expressão do mRNA do VEGF, Flt-1 e KDR no placentoma, região interplacentomal e corpo lúteo em diferentes fases gestacionais em bovinos clonados e não clonados

Dissertação apresentada ao Programa de Pósgraduação em Anatomia dos Animais Domésticos e Silvestres da Faculdade de Medicina Veterinária e Zootecnia da Universidade de São Paulo para obtenção do título de Mestre em Ciências

Aprovado em: $31 / 05 / 2006$

\section{Banca Examinadora} Prof. Dr. Pancedic Proz
Julgamento: Aromenes Bromado

Prof. Dr. Jose his A $1, n z 0$ Julgamento: APPOUADO

Prof. Dr. Josí Bunatin: J Julgamento:
Instituição: FMVE $\quad$ F

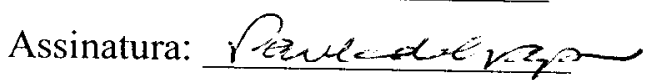

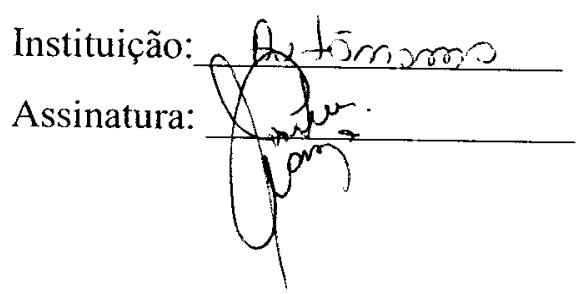

Instituição: UNESP BorvCATi

Assinatura:

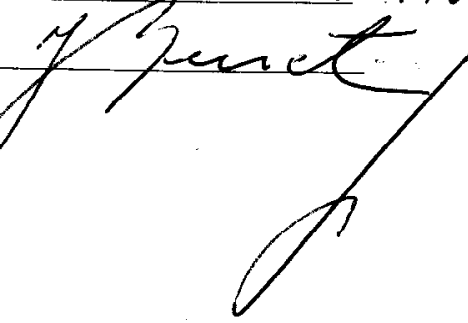


"Pois será como a árvore plantada junto a ribeiros de águas, a qual dá o seu fruto no seu tempo: as suas folhas não cairão, $e$ tudo quanto fizer prosperará" 


\section{Dedicatória}

À minha mãe Mara Regina Albuquerque. Minha vinda a São Paulo não seria possível sem você, que sempre me apoiou, esteve sempre ao meu lado, e com muita força lutou para que eu terminasse esta jornada. Muito obrigado, te amo, ...

Ao meu pai Alberto Garbelotti, que sempre fez o melhor, em todos os momentos foi um sábio. Que seus conselhos permaneçam para sempre. Te adoro...

Ao meu irmão e familia Alberto Garbelotti Filho, Sandra e Maria Eduarda, que nunca esconderam o carinho que tinham por mim, sempre com sorriso nos olhos demonstraram incentivo e dedicação...

Aos meus avós Altino. Izelda e Francisco que permanecem na minha memória e na minha vida, adoro vocês...

Aos meus tios Álvaro, Junior, Joel, Ligia, Nice e Rose. Desde a faculdade deram o maior incentivo, e quando eu precisei, estavam ali do meu lado, sempre lembrarei de todos, valeu... 


\section{Dedicatória especial}

"A minha orientadora Prof. Dra. Paula de Carvalho Papa, que representou muito uma família, à qual para mim foi como uma irmã em muitos momentos. Sempre, quando eu olhar para trás, vou lembrar o quanto valeu aprender com você, por tudo que passamos. Nunca deixarei de lado todo o esforço e paciência que foi dedicado a mim"

Muito obrigado... 
Oferecimento

Em memorian

Ofereço esta dissertação a minha avó querida Anita Gaspari Albuquerque. Histórias maravilhosas sempre serão lembradas. Tenho saudades daqueles momentos que passamos juntos: sempre acreditei que as suas palavras valeriam para o resto da minha vida. Em minha memória permanece a seguinte frase: "A maior herança que um pai pode deixar para um filho é o estudo, dinheiro nenhum compra a sabedoria, pode acreditar..." Sempre vou levar as suas lembranças de afeto, carinho, mãe, avó, mulher de caráter, conselheira, e amiga. Neste presente momento, aonde quer que a senhora esteja, sei que nunca vai esquecer de $\operatorname{mim} . .$.

beijos e saudades 


\section{Agradecimentos}

Ao Professor. Pedro Primo Bombonato e à Professora. Maria Angélica Miglino por terem me recebido no departamento desde o estágio final de conclusão do curso até o mestrado. Sou muito grato por tudo...

Aos Professores. Francisco Javier Hernandez Blazquez e José Roberto Kfoury Jr. por terem disponibilizado seus laboratórios e materiais...

Ao Professor. Dr. José Buratini Jr, Anthony Castilho e Mariana do Laboratório de Biologia Molecular do Departamento de Fisiologia da Universidade Estadual Paulista (UNESP), Campus de Botucatu, por me acolherem tão bem, para que eu pudesse processar meu material, e pelo vínculo de amizade que sempre permanecerá...

Ao Laboratório de Oncologia Experimental do Departamento de Patologia, da Faculdade de Medicina Veterinária e Zootecnia da Universidade de São Paulo (VPT - FMVZ/USP), sob coordenação da Professora. Dra. Maria Lúcia Zaidan Dagli por ter cedido o uso do aparelho de PCR para que eu pudesse analisar minhas amostras, e pela colaboração e atenção. Ao José Luis Avanzo, por vários dias de dedicação até horas da noite juntos no laboratório. E não poderia deixar de agradecer em dobro, por tudo que me proporcionou de conhecimento e dedicação do seu tempo a mim. Valeu, muito obrigado...

Aos colegas do laboratória de patologia Heidge, Márcia, Tereza, Bruno, Heloísa, Patrícia, Kátia, Lucas. Muito obrigo por terem proporcionado dias felizes neste laboratório...

Ao meus colegas do laboratório (LEME) Cadu, Danila, Laura, Eduardo, Vanessa Amaral, Alex, Margareth, Selene, Vanessa Uemura, Fábio, Mariana, que serão lembrados não apenas pela amizade, mas sim pelo apoio e boa vontade para tudo. Sou grato a todos, valeu...

Aos amigos da pós-graduação Cristiane Takamine, Ricardo Romão Guerra, Thiago Aloia, Káterin Grondona, David Montes, Procássia Lacerda, Josy Alvarenga, Camila Trevisan, Flávio, Fabi, Joel, Cláudia, Evander $e$ Guilherme e muitos outros amigos que participaram juntos 
nesta caminhada, com muita alegria e descontração nos momentos difíceis e felizes que passamos...

Ao Índio, Diogo Palermo, João, Raimundo, técnicos do setor de anatomia por terem fornecido conhecimentos que sempre serão lembrados...

Ao Maicon e a Jaqueline, pela atenção em todos os momentos, obrigado...

À minha namorada Mirela Aline Real de Lima pela amizade, afeto $e$ carinho, pois me deu a maior força. Eu adoro você minha linda, muito obrigado...

Esta dissertação teve o apoio financeiro da:

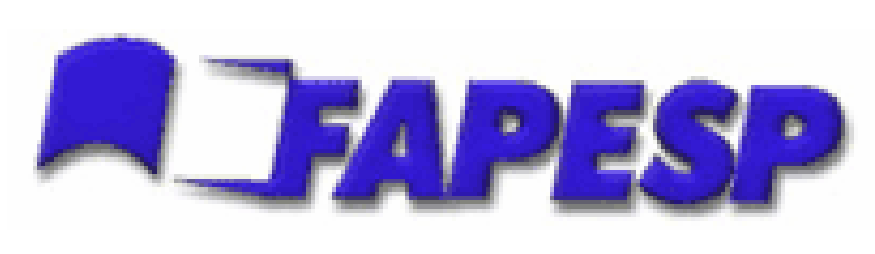

Fundação de Amparo a Pesquisa do Estado de São Paulo Processo 04/04084-5 


\section{RESUMO}

GARBELOTTI, F. Expressão do mRNA do VEGF, FIt-1 e KDR no placentoma, região interplacentomal e corpo lúteo em diferentes fases gestacionais em bovinos clonados e não clonados. [Expression of mRNA of the VEGF, FIt-1 and KDR in the placentome, interplacentomal areas and corpus luteum in different phases of pregnancy in cloned and no cloned bovines]. 2006. 111 f. Dissertação (Mestrado em Ciências) - Faculdade de Medicina Veterinária e Zootecnia, Universidade de São Paulo, São Paulo, 2006.

O VEGF é um fator mitogênico específico de células endoteliais que promove diferenciação celular materno-fetal placentária quando ligado a seus receptores (Flt-1 e KDR). Sua expressão é controlada por mecanismos autócrinos e parácrinos e está associada ao desenvolvimento da placenta. A placenta bovina foi utilizada como modelo de estudo por apresentar a facilidade de se avaliar os componentes do sistema VEGF em diferentes fases gestacionais. Como objetivo este estudo buscou analisar o fator de crescimento vascular endotelial (VEGF) e seus receptores através da técnica de PCR em tempo real no início, meio e fim de gestação. Para tanto, amostras de placentomas, região interplacentomal e corpo lúteo foram coletadas em diferentes fases gestacionais. Foram utilizados placentomas de animais clonados obtidos apenas aos 270 dias de gestação e estas amostras foram comparadas aos animais não clonados na mesma fase. A expressão do VEGF no placentoma apresentou um decréscimo ( $p<0.05)$ no final da gestação (270 dias) em relação à expressão do VEGF aos 90 dias. A expressão do Flt-1 e do KDR na região interplacentomal foi semelhante desde os 45 até 90 dias de gestação e apresentou um aumento significativo $(p<0.05)$ aos 150 dias. No corpo lúteo gestacional, a expressão do VEGF aos 210 dias foi maior $(p \leq 0.05)$ em relação a 90 e 150 dias; observou-se também baixa expressão do KDR aos 90 dias de gestação $(p<0.05)$ em relação aos 210 dias. Pode-se concluir que a regulação da expressão do VEGF variou em relação aos seus receptores nos três tecidos avaliados. Placentomas de bovinos clonados não apresentaram diferenças significativas em relação à expressão do sistema VEGF se comparados aos 
placentomas de animais não clonados sugerindo ser esta expressão equivalente em placentas de animais clonados que vieram a termo.

Palavras-chave: Fatores de crescimento, expressão do mRNA, clones, placenta, bovino 


\begin{abstract}
GARBELOTTI, F. Expression of mRNA of the VEGF, FIt-1 and KDR in placentome, interplacentomal areas and gestational corpus luteum in different phases of pregnancy in cloned and non-cloned bovines. [Expressão do mRNA do VEGF, Flt-1 e KDR no placentoma, região interplacentomal e corpo lúteo em diferentes fases gestacionais em bovinos clonados e não clonados.]. 2006. 111 f. Dissertação (Mestrado em Ciências) Faculdade de Medicina Veterinária e Zootecnia, Universidade de São Paulo, São Paulo, 2006.
\end{abstract}

The VEGF is a specific endothelial mitogenic factor that promotes feto-maternal cell differentiation in placenta through binding to its receptors (Flt-1 and KDR). Their expression is controlled by autocrine and paracrine mechanisms that are associated to placenta development. The bovine placenta was used in this study as a model due to easiness of evaluation of VEGF system components in different phases of pregnancy. The objective of this study was to analyze the vascular endothelial growth factor (VEGF) and its receptors expression using the real time PCR technique in the beginning, half and end of pregnancy. Furthermore, placentome samples, interplacentomal areas and corpus luteum were collected in different gestational phases for comparative studies. Placentome of cloned animals were analyzed at 270 days of pregnancy and compared to non-cloned animals in the same phase. The expression of VEGF in the placentome presented a decrease of expression $(p<0.05)$ in the end of the gestation (270 days) in relation to 90 days. The expression of Flt-1 and of KDR in interplacentomal area was similar from 45 to 90 days of pregnancy with a significant increase $(p<0.05)$ observed at 150 days. In the gestational corpus luteum, the expression of VEGF at 210 days was higher $(p \leq 0.05)$ in comparison to 90 and 150 days. In the same tissue KDR expression at 90 days was lower $(p<0.05)$ in relation to 210 days. In conclusion the regulation VEGF varied in relation to its receptors expression in all three studied tissues. Cloned placentomes showed no significant differences in VEGF system expression compared to the placentome of non-cloned animals, suggesting there is an equivalent expression in placentas from cloned animals that came to term.

Key Words: Growth Factors, RNAm of expression, clone, placenta, bovine 


\section{LISTA DE FIGURAS}

Figura 1 - A imagem mostra fetos bovinos em início de gestação, com aproximadamente 30,40 e 50 dias de gestação. Os fetos estão envolvidos pela membrana amniótica repleta de líquido transparente. A membrana corioalantóidea foi aberta para demonstrar melhor o saco amniótico. Os vasos placentários estão evidentes estendendo-se a partir do feto, ao longo do cordão umbilical, em sentido do corioalantóide, qual inicia adesão no endométrio ao redor dos 33 dias de gestação. Os cotilédones ainda não estão aparentes. Fonte: Schlafer et al; 2000 .

Figura 2 - Esquema geral do PCR em Tempo Real. A. Equipamento ABI Prism ${ }^{\circledR}$ 7500. B. Observa-se os componentes principais da reação em tempo real, os primers ligados, as sondas ligadas a seus respectivos reporter e quencher e a taq polimerase. Para que não seja amplificado DNA genômico é aconselhado pelo fabricante que os mesmos sejam desenhados em éxons diferentes, embora isto não seja uma regra. C. Início da reação de amplificação, com a extensão dos primers e atividade 5' exonuclease da taq, com liberação do reporter. D. Extensão completa com a liberação completa do reporter. E. Apresentação das etapas do PCR em tempo real. Step 1: ativação da UNG; Step 2: primeira extensão; Step 3: inativação da UNG; Step 4: Desnaturação da dupla fita, ligação da sonda a $70^{\circ} \mathrm{C}$ e dos primers a $60^{\circ} \mathrm{C}$ com extensão dos produtos de PCR. F. Funcionamento do sistema óptico de detecção da fluorescência. G. Resultado de uma titulação de PCR. H. Esquema mostrando o limiar de corte, posicionado na fase exponencial e os seus respectivos Cts (número de ciclo). Adaptado de Avanzo (2005).....

Figura 3 - Esquema representando a sonda fluorescente do sistema TaqMan. Segundo os critérios da Applied Biosystems, o melhor local para a construção da sonda é a junção éxon-éxon. Portanto, sempre que possível este critério foi adotado. No entanto, isto é mais indicado quando não se faz o tratamento com DNAse I. Enquanto unidos, a fluorescência emitida pelo repórter é capturada pelo quencher. Durante a reação a probe é clivada ocorrendo a separação do fluoróforo e do quencher. Neste instante a fluorescência emitida é registrada pelo equipamento. MGB ( Minor Groove Binder - Tm enchancer) ou o aumento dos número de bases na sequência aumentam a diferença em $10^{\circ} \mathrm{C}$ em relação aos primers, ou seja, primer $60^{\circ} \mathrm{C}$ de temperatura de anelamento; sonda $70^{\circ} \mathrm{C}$ 
Figura 4 - $\quad$ Expressão relativa do mRNA do VEGF(A), Flt-1 (B) e KDR (C) em placentoma bovino em diferentes idades gestacionais. Os dados obtidos por PCR em tempo real foram normalizados ao GADPH. Os resultados representam média desvio padrão de 4 observações por grupo (90 a 270 dias) ou uma observação (45 e 60 dias). * $p \quad 0.05$ vs. 90

Figura 5 - $\quad$ Expressão relativa do mRNA do VEGF(A), Flt-1 (B) e KDR (C) em placentoma bovino aos 270 dias de gestação de clones e de fetos não manipulados. Os dados obtidos por PCR em tempo real foram normalizados ao GADPH. Os resultados representam média desvio padrão de 4 e 8 observações para não clone e clone, respectivamente

Figura 6- $\quad$ Expressão relativa do mRNA do VEGF(A), Flt-1 (B) e KDR (C) em placentoma bovino aos 270 dias de gestação. Os dados obtidos por PCR em tempo real foram normalizados ao GADPH. Os resultados representam média desvio padrão de 4 observações por grupo.

Figura 7- $\quad$ Expressão relativa do mRNA do VEGF(A), Flt-1 (B) e KDR (C) em placentoma bovino aos 270 dias de gestação. Os dados obtidos por PCR em tempo real foram normalizados ao GADPH. Os resultados representam expressão individual nas amostras de animais não clonados (270d) e de animais clonados (nomes ou números).

Figura 8 - Expressão relativa do mRNA do VEGF e receptores na região interplacentomal em diferentes fases gestacionais. Os dados obtidos por PCR em tempo real foram normalizados ao GADPH. Os resultados representam média desvio padrão de 4 observações por grupo (90 a 210 dias) ou uma observação (45, 60 e 270 dias). * $p \leq$ 0.05 vs. 90 .

Figura 9 - Expressão relativa do mRNA do VEGF e receptores no corpo lúteo gestacional em diferentes fases gestacionais. Os dados obtidos por PCR em tempo real foram normalizados ao GADPH. Os resultados representam média desvio padrão de 4 observações por grupo (90 a 210 dias) ou uma observação (45 e 60 dias). ${ }^{*} p \leq 0.05$ vs. 210 ...... 


\section{LISTA DE QUAROS}

Quadro 1 - Mostra o exemplo de uma corrida de RT-PCR qualitativo e os reagentes usados durante a reação para o GAPDH na placenta bovina.

Quadro 2 - Primers, probes e seus respectivos produtos de amplificação*Carcterísticas de monitoramento dos sinais fluorescentes do sistema 7000 ou 7500 gerados durante o PCR pelos fluoróforos $\mathrm{FAM}^{\mathrm{TM}}$, e $\mathrm{VIC}^{\mathrm{TM}}$. = forward; 4 = reverse. Os primers e probes para a VEGF, Flt-1 e KDR foram desenhados pelo serviço Assays-by-Design ${ }^{\text {'M }}$ de expressão gênica (Applied Biosystems); GAPDH foi desenhado pelo Custon Oligo Synthesis Service (Applied Biosystems, Foster City, USA).

Quadro 3 - Protocolo de termociclagem universal

Quadro 4 - Valores de eficiência de cada primer utilizado nos experimentos....

Quadro 5 - Representa a corrida de PCR em tempo real com os valores de cada Ct para o GADPH e VEGF, e a média das duplicatas realizadas para cada amostra. DCP alvo representa o calibrador menos o gene alvo, DCP ref. representa o calibrador menos o controle endógeno, EDCP alvo representa a eficiência elevada a $\triangle \mathrm{DCP}$ alvo, EDPC ref. representa a eficiência elevada a $\triangle \mathrm{DCP}$ ref, Exp. Rel. representa EDPC alvo dividido pelo EDPC ref.

Quadro 6 - Representa a corrida de PCR em tempo real com os valores de cada (Ct) para o Flt-1, e a média das duplicatas realizadas para cada amostra. DCP alvo. representa o calibrador menos o gene alvo, DCP ref. representa o calibrador menos o controle endógeno, EDCP alvo representa a eficiência elevada a $\triangle \mathrm{DCP}$ alvo, EDPC ref. representa a eficiência elevada a $\triangle D C P$ ref, Exp. Rel. representa EDPC alvo dividido pelo EDPC ref.

Quadro 7 - Representa a corrida de PCR em tempo real com os valores de cada (Ct) para o KDR, e a média das duplicatas realizadas para cada amostra. DCP alvo representa o calibrador menos o gene alvo, DCP ref. representa o calibrador menos o controle endógeno, EDCP alvo representa a eficiência elevada a $\triangle \mathrm{DCP}$ alvo, EDPC ref. representa a eficiência elevada a $\triangle D C P$ ref, Exp. Rel. representa EDPC alvo dividido pelo EDPC ref. 
Quadro 8 - Representa a corrida de PCR em tempo real com os valores de cada (Ct) para o GADPH e VEGF, e a média das duplicatas realizadas para cada amostra. DCP alvo representa o calibrador menos o gene alvo, DCP ref. representa o calibrador menos o controle endógeno, EDCP alvo representa a eficiência elevada a $\triangle \mathrm{DCP}$ alvo, EDPC ref. representa a eficiência elevada a $\triangle \mathrm{DCP}$ ref, Exp. Rel. representa EDPC alvo dividido pelo EDPC ref.

Quadro 9 - Representa a corrida de PCR em tempo real com os valores de cada (Ct) para o Flt-1, e a média das duplicatas realizadas para cada amostra. . DCP alvo representa o calibrador menos o gene alvo, DCP ref. representa o calibrador menos o controle endógeno, EDCP alvo representa a eficiência elevada a $\triangle \mathrm{DCP}$ alvo, EDPC ref. representa a eficiência elevada a $\triangle D C P$ ref, Exp. Rel. representa EDPC alvo dividido pelo EDPC ref.

Quadro 10 - Representa a corrida de PCR em tempo real com os valores de cada (Ct) para o KDR, e a média das duplicatas realizadas para cada amostra. DCP alvo representa o calibrador menos o gene alvo, DCP ref. representa o calibrador menos o controle endógeno, EDCP alvo representa a eficiência elevada a $\triangle \mathrm{DCP}$ alvo, EDPC ref. representa a eficiência elevada a $\triangle D C P$ ref, Exp. Rel. representa EDPC alvo dividido pelo EDPC ref

Quadro 11 - Representa a corrida de PCR em tempo real com os valores de cada $(\mathbf{C t})$ para o GADPH e VEGF, e a média das duplicatas realizadas para cada amostra. DCP alvo representa o calibrador menos o gene alvo, DCP ref. representa o calibrador menos o controle endógeno, EDCP alvo representa a eficiência elevada a $\triangle \mathrm{DCP}$ alvo, EDPC ref. representa a eficiência elevada a $\triangle \mathrm{DCP}$ ref, Exp. Rel. representa EDPC alvo dividido pelo EDPC ref

Quadro 12 - Representa a corrida de PCR em tempo real com os valores de cada $(\mathbf{C t})$ para o Flt-1, e a média das duplicatas realizadas para cada amostra. DCP alvo representa o calibrador menos o gene alvo, DCP ref. representa o calibrador menos o controle endógeno, EDCP alvo representa a eficiência elevada a $\triangle \mathrm{DCP}$ alvo, EDPC ref. representa a eficiência elevada a $\triangle D C P$ ref, Exp. Rel. representa EDPC alvo dividido pelo EDPC ref

Quadro 13 - Representa a corrida de PCR em tempo real com os valores de cada (Ct) para o KDR, e a média das duplicatas realizadas para cada amostra. . DCP alvo representa o calibrador menos o gene alvo, DCP ref. representa o calibrador menos o controle endógeno, EDCP alvo representa a eficiência elevada a $\triangle \mathrm{DCP}$ alvo, EDPC ref. representa a eficiência elevada a $\triangle D C P$ ref, Exp. Rel. representa EDPC alvo dividido pelo EDPC ref. 
Quadro 14 - Representa a corrida de PCR em tempo real com os valores de cada (Ct) para o GADPH e VEGF, e a média das duplicatas realizadas para cada amostra. DCP alvo representa o calibrador menos o gene alvo, DCP ref. representa o calibrador menos o controle endógeno, EDCP alvo representa a eficiência elevada a $\triangle \mathrm{DCP}$ alvo, EDPC ref. representa a eficiência elevada a $\triangle \mathrm{DCP}$ ref, Exp. Rel. representa EDPC alvo dividido pelo EDPC ref

Quadro 15 - Representa a corrida de PCR em tempo real com os valores de cada (Ct) para o Flt-1, e a média das duplicatas realizadas para cada amostra. DCP alvo representa o calibrador menos o gene alvo, DCP ref. representa o calibrador menos o controle endógeno, EDCP alvo representa a eficiência elevada a $\triangle \mathrm{DCP}$ alvo, EDPC ref. representa a eficiência elevada a $\triangle D C P$ ref, Exp. Rel. representa EDPC alvo dividido EDPC ref

Quadro 16 - Representa a corrida de PCR em tempo real com os valores de cada (Ct) para o KDR, e a média das duplicatas realizadas para cada amostra. DCP alvo representa o calibrador menos o gene alvo, DCP ref. representa o calibrador menos o controle endógeno, EDCP alvo representa a eficiência elevada a $\triangle \mathrm{DCP}$ alvo, EDPC ref. representa a eficiência elevada a $\triangle$ DCP ref, Exp. Rel. representa EDPC alvo dividido pelo EDPC ref 


\section{LISTA DE ABREVIATURAS}

bFGF Fator de crescimento fibroblástico básico

cDNA Ácido desoxirribonucléico complementar

CL $\quad$ Corpo Lúteo

FGF Fator de crescimento fibroblastico

Flt Fms-like tyrosine Kinase

Foward Primer lido pela Taq polimerase no sentido 5' -3 '

FSH Hormônio folículo estimulante

KDR Kinase insert domain containing receptor

LH Hormônio luteinizante

MAPK Proteína quinase ativada por mitógeno

mRNA Acido ribonucléico mensageiro

PCR Reação de polimerização em cascata

Primer Seqüência de aminoácidos de 20 pb

Probe Seqüência de oligonucleotídeos (20 pb) que contém os fluoróforos

Reverse Primer lido pela Taq polimerase no sentido 3' -5 '

RT-PCR Reação de polimerização em cadeia a partir de RNA, utilizando a enzima transcriptase reversa

VEGF Fator de crescimento vascular endotelial

VEGFR Receptor para o fator de crescimento vascular endotelial 
$1 \quad$ INTRODUÇÃO

2 OBJETIVOS

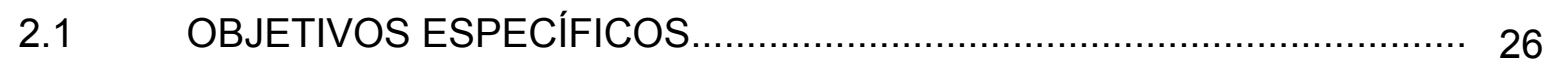

$3 \quad$ REVISÃO DA LITERATURA

$3.1 \quad$ PLACENTA

3.1.1 Desenvolvimento da placenta bovina ………............................... 28

3.2 ANGIOGENESE E VASCULOGENESE........................................... 31

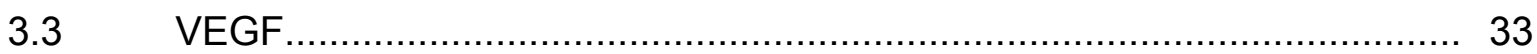

3.3.1 Receptores para o VEGF na placenta............................................... 36

$3.4 \quad$ CORPO LÚTEO GESTACIONAL BOVINO.......................................... 38

3.4.1 VEGF e receptores no corpo lúteo gestacional................................... 39

$3.5 \quad$ BOVINOS CLONADOS ............................................................. 41

4 MATERIAL E MÉTODO ........................................................... 43

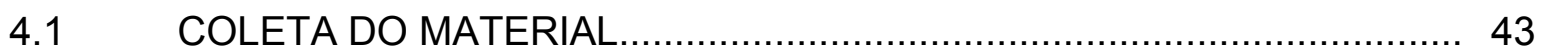

4.2 ACONDICIONAMENTO DAS AMOSTRAS ........................................ 43

4.3 PROCEDIMENTOS EXPERIMENTAIS............................................. 44

4.3.1 Descrição de método de Trizol ${ }^{\circledR}$ (Invitrogen) para extração do RNA 44 total

4.3.1.1 Quantificação do RNA total........................................................... 45

4.3.2 Transcrição reversa (construção da fita de DNA complementar)...... 46

4.3.3 PCR para o controle da qualidade do cDNA ......................................... 46

4.4 .PCR EM TEMPO REAL NO ABRIPRISMA 7000 E 7500 SEQUENCE 47 DETECTION SYSTEMS (APPLIED BIOSYSTEMS).

4.4.1 Primers e probes. 
4.5 CONDIÇÕES DA REAÇÃO DE REAL TIME PCR.................................. 55

4.6 INTERPRETAÇÃO DOS RESULTADOS OBTIDOS NO SISTEMA DE 56 REAL TIME PCR.

4.7 PREPARO DA SOLUÇÃO PARA EFICIÊNCIA DO PRIMER.................... 57

4.8 AVALIAÇÃO DA EFICIÊNCIA DOS PRIMERS UTILIZADOS.................... 58

4.9 ANÁLISE ESTATISTICA DOS RESULTADOS..................................... 58

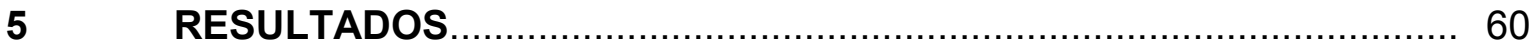

5.1 EXPRESSÃO DO VEGF, FLT-1 E KDR NO PLACENTOMA BOVINO..... 60

5.2 EXPRESSÃO DO VEGF, FLT-1 E $\quad$ KDR NA REGIÃO 66 INTERPLACENTOMAL BOVINO

5.3 EXPRESSÃO DO VEGF, FLT-1 E KDR NO CORPO LÚTEO 69 GESTACIONAL BOVINO

6

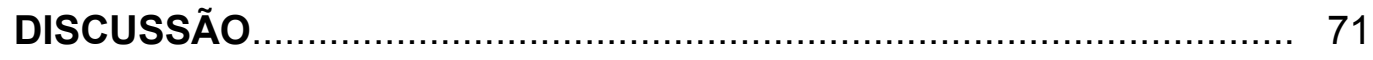

$7 \quad$ CONCLUSÕES

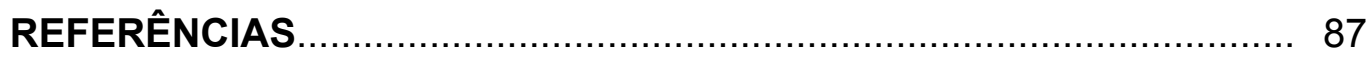

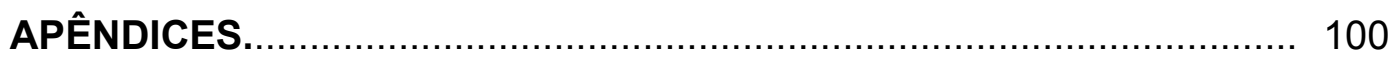


1 INTRODUÇÃO 


\section{INTRODUÇÃO}

Nas duas últimas décadas, a importância do crescimento vascular no funcionamento normal ou anormal do aparelho reprodutor feminino vem sendo reconhecida. Assim, modelos animais importantes para o estudo da placenta desde os tempos mais remotos, tiveram o seu conhecimento de anatomia placentária e de fisiologia através de estudos comparativos em animais dómesticos (REYNOLDS et al., 2004).

A angiogênese placentária resulta principalmente na formação e crescimento de um leito vascular placentário. Considerando a regulação placentária influenciada por mecanismos autócrinos e parácrinos, o fator de crescimento vascular endotelial (VEGF) e seus receptores, são capazes de modificar a magnitude do fluxo sanguíneo uterino placentário influenciando o desenvolvimento fetal (REYNOLDS et al., 2004). As proteínas do sistema VEGF foram descritas na espécie como presentes nas células do trofoblasto e epitélio uterino do placentoma e também na região interplacentomal, desde a implantação embrionária até o final da gestação, e indicam que funções clássicas de angiogênese e permeabilidade vascular induzidas pelo fator de crescimento, não apenas facilitam a troca materno-fetal através de mecanismos parácrinos e autócrinos, como são fundamentais durante toda a gestação (PFARRER et al., 2005).

Além da placenta, o corpo lúteo $(\mathrm{CL})$ como parte do sistema reprodutivo, é uma glândula temporária que produz progesterona (P4), exigido para 0 estabelecimento e manutenção da gestação. Embora a regulação do corpo lúteo cíclico da espécie bovina tenha sido estudada durante várias décadas, muitos de seus mecanismos regulatórios envolvidos na vascularização ainda não foram entendidos (SCHAMS; BERISHA, 2004). O corpo lúteo gestacional bovino funciona em conjunto com a placenta para a manutenção da gestação (HAFEZ, 1995). Sua vascularização já foi descrita por Berisha et al. (2000) mas ainda não foi estudada em nível molecular. 
As perdas iniciais e tardias dos animais clonados relacionam-se principalmente a alterações no processo de reprogramação nuclear (KONO, 1998; YOUNG; FAIRBURN, 2000). Estas alterações determinam diferentes padrões de expressão em determinados genes (NIEMANN et al., 2002); uma vez que os animais clonados são mais vulneráveis, ou seja, susceptíveis a mortes prematuras. Considerando-se que o VEGF, um potente fator angiogênico, tem importância fundamental para a manutenção da gestação dos animais clonados e não clonados, Campos (2005) descreveu a influência do mesmo sobre a esteroidogênese placentária em animais clonados e não clonados ressaltando possíveis diferenças na modulação da expressão gênica nestes animais.

O entendimento do mecanismo de controle da vascularização durante a gestação de bovinos clonados e não clonados pode contribuir para esclarecer pontos importantes ainda não vistos na literatura com relação à fisiopatologia da gestação; alterações da expressão gênica de fatores de crescimento relacionados à vascularização podem ser uma das causas do padrão de vascularização placentária anormal descrita nos animais clonados.

A expressão do sistema VEGF ao longo da gestação bovina pode ser um reflexo da condição reprodutiva geral e mesmo do status de fertilidade do rebanho. Buscou-se padronizar a expressão "normal" ao longo da gestação para que possíveis alterações de sua regulação possam ser identificadas. A importância da vascularização na eficiência placentária está bem estabelecida, e acreditamos que este estudo possa trazer futuros benefícios ao manejo gestacional de animais clonados e não clonados. 
2 OBJETIVOS 


\section{OBJETIVOS}

Hipotetizou que a expressão do mRNA do VEGF e seus receptores na placenta e corpo lúteo de bovinos ao longo da gestação reflete as modificações de vascularização observadas. Além disso, hipotetizou-se que placentas de animais clonados apresentam expressão diferente do sistema VEGF.

\subsection{OBJETIVOS ESPECÍFICOS}

1 Estudar a expressão do fator de crescimento vascular endotelial (VEGF) e seus receptores VEGFR-1 (Flt-1) e VEGFR-2 (KDR) no placentoma, região interplacentomal e corpo lúteo, no inicio, meio e fim da gestação em animais com gestação não manipuladas.

2 Comparar a expressão do sistema VEGF nas amostras de placentoma obtidas aos 270 dias de gestação de animais clonados comparando-os aos não clonados na mesma fase.

3 Identificar possíveis alterações na regulação da expressão do sistema VEGF na placenta e corpo lúteo gestacional. 


\section{REVISÃO DA LITERATURA}




\section{REVISÃO DE LITERATURA}

O nome placenta aparece na nomenclatura anatômica apenas no século XVI: Realdus Columbus (1516-1559), discípulo de Vesalius, em seu livro De $\boldsymbol{R e}$ Anatômica utilizou a expressão in modum orbicularis placentae (a modo de um bolo redondo) enquanto Fallopius (1523-1562) denominou o órgão de placenta uterina.

\subsection{PLACENTA}

A placenta bovina, composta por vilosidades coriais e pelo endométrio, é responsável por trocas metabólicas materno-fetais, síntese de hormônios e termorregulação. São as vilosidades coriônicas que justapõem as circulações materna e fetal, permitindo amplas trocas de substâncias (tais como gases, nutrientes, hormônios, eletrólitos, anticorpos entre outros), sem haver comunicação direta entre elas (GRUNERT; BIRGEL, 1984). Estas substâncias são transportadas por meio da barreira placentária ou por um dos quatro seguintes mecanismos: difusão simples, difusão facilitada, transporte ativo e pinocitose (PAGE; VILLEE, 1972).

Os hormônios protéicos, como, por exemplo, o lactogênio placentário (hCG), são hormônios que não chegam ao embrião em quantidades significativas, já os hormônios esteróides não conjugados atravessam livremente a membrana plasmática, no entanto, quando ligados a proteínas não são capazes de atravessar a barreira placentária (MOORE, 2000). Estrógenos e progestágenos bem como alguns hormônios protéicos são sintetizados a partir de precursores do feto, da mãe, ou de ambos e secretados pelas células binucleadas do trofoblasto da placenta bovina (MOORE, 2000).

\subsubsection{Desenvolvimento da placenta bovina}

Após a fertilização o embrião passa por estágios de divisão celular, além de modelagem e compactação (estágio de mórula), nos quais ocorre a formação dos 
blastômeros e blastocele que originarão o blastocisto, o qual, por sua vez, originará o embrião e as membranas fetais (SCHLAFER et al., 2000).

Os embriões humanos e bovinos são similares em aspectos relacionados à regulação da ativação do genoma, aspectos metabólicos, duração do desenvolvimento e préimplantação embrionária (SON et al., 2002; AUGUSTIN et al., 2000).

A implantação do blastocisto, união e adesão do trofoblasto com o epitélio materno, são eventos que, no início da gestação, favorecem a comunicação materna e fetal. Por volta do $19^{\circ}$ dia de gestação na espécie humana, ocorre a fixação definitiva da placenta através dos microvilos (KING et al., 1982). Nos bovinos, o blastocisto é formado após 7 dias da inseminação e o primeiro sinal de implantação acontece duas semanas mais tarde, aos 21 dias, como descrito por Guillonot (1995). As variações epigenéticas, ou seja, variações que acontecem depois da transcrição do gene sem que haja qualquer alteração no DNA, interferem na diferenciação celular do blastocisto durante o desenvolvimento embrionário de animais tanto clonados quanto ao clonados (OHGANE et al., 2002).

O blastocisto se expande envolvendo uma estrutura composta por três camadas de células (trofoectoderma, mesoderma e endoderma). O amnion (o qual, em conjunto com o alantóide, saco vitelino e corion compõem as membranas fetais), forma um envoltório de células do trofoectoblasto, próximos ao embrião, produzindo um espaço que posteriormente será preenchido por fluidos em volta do embrião. O alantóide recebe vasos sanguíneos que transportam o sangue para região do corion e amnion (SCHLAFER et al., 2000). O alantóide e o corion se fundem para formar o corioalantóide. A espécie bovina apresenta uma forma definitiva para placenta, do tipo corioalantoideana, seguido de uma conexão entre a circulação fetal e os vasos alantóideanos (LEISER et al.,1997; KAUFMANN, 1994, Figura 1).

Nos ruminantes, o endométrio possui áreas especializadas chamadas de carúnculas, semelhantes a botões. Nestes locais ocorre remodelamento das membranas fetais, o 
que origina estruturas denominadas de cotilédones, localizadas no lado fetal da placenta. O desenvolvimento das projeções de vilos origina interdigitações na superfície da carúncula e a formação de criptas (SCHLAFER et al., 2000) facilitando a ligação materna e fetal, o que proporciona um maior desenvolvimento do feto (SCHLAFER et al., 2000). A combinação dos tecidos caruncular e cotiledonário é denominada de placentoma e apresenta-se como uma estrutura bem vascularizada, semelhante a um cogumelo de forma irregular. Entre os placentomas existem espaços denominados de regiões interplacentomais, cuja função é a de comunicação entre os placentomas, o que acontece por meio de uma ampla rede de vasos sanguíneos, que aumentam de número principalmente no terço final de gestação dos bovinos.

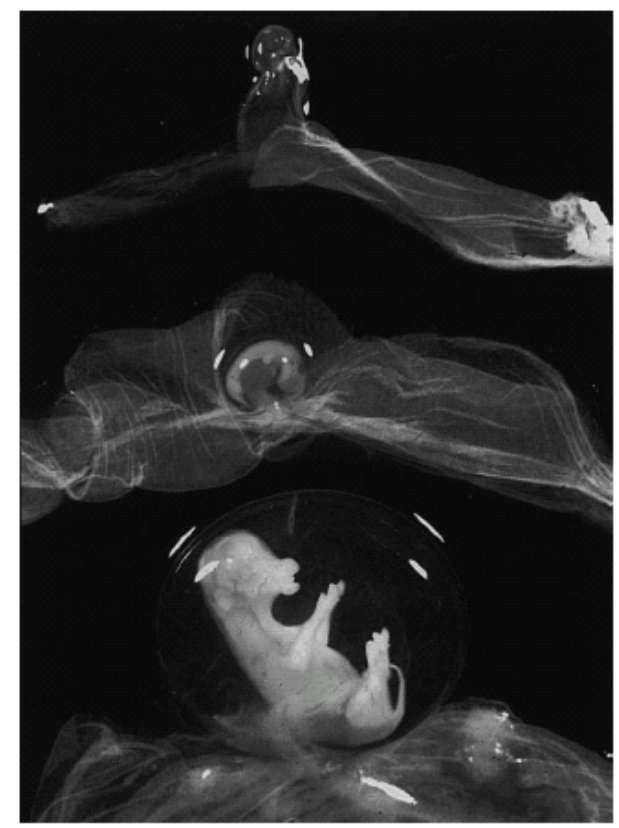

Fonte : Schlafer et al., 2000

Figura. 1 - A imagem mostra fetos bovinos em início de gestação, com aproximadamente 30, 40 e 50 dias de gestação. Os fetos estão envolvidos pela membrana amniótica repleta de líquido transparente. A membrana corioalantóidea foi aberta para demonstrar melhor o saco amniótico. Os vasos placentários estão evidentes estendendo-se a partir do feto, ao longo do cordão umbilical, em sentido do corioalantóide, qual inicia adesão no endométrio ao redor dos 33 dias de gestação. Os cotilédones ainda não estão aparentes 


\subsection{ANGIOGÊNESE E VASCULOGÊNESE}

A angiogênese é caracterizada pela formação de uma nova rede vascular a partir de vasos pré-existentes. Em geral, o processo angiogênico é iniciado pela ação de fatores de crescimento, os quais atuam aumentando a permeabilidade dos vasos, estimulando a degradação proteolítica da matriz extracelular através de proteases específicas e favorecendo a proliferação de células endoteliais. O declínio no número dos vasos sanguíneos na placenta reflete a diminuição de estímulos angiogênicos (REYNOLDS; KILLILEA; REDMER, 1992; RISAU, 1997; TORRY, 1998;).

Os processos de vasculogênese são caracterizados pelo desenvolvimento capilar a partir de diferenciação de células precursoras de origem mesenquimal, sendo um processo envolvido na formação dos vasos ocorrida durante a embriogênese (DíAZFLORES, 1994 apud CAMPOS, 2005). Os fatores envolvidos neste processo são os mesmos fatores angiogênicos que também contribuem para vários processos fisiológicos e patológicos, incluindo desenvolvimento embrionário, cicatrização, crescimento e processos metastáticos de tumores, retinopatia diabética, revascularização de isquemia do miocárdio, formação do corpo lúteo, crescimento do endométrio, implantação do embrião e placentação (FOLKMAN, 1992). A angiogênese fisiológica e a patológica compartilham três aspectos muito importantes: a proliferação, migração e invasão através da matriz extracelular e habilidade de acessar a rede vascular pré-existente em busca de suprimento sanguíneo (ZYGMUNT et al., 2003). Em indivíduos adultos, a angiogênese fisiológica acontece exclusivamente no trato reprodutor feminino a cada novo ciclo e na placenta, a cada nova gestação (ZYGMUNT et al., 2003).

O sucesso da gestação depende de funções angiogênicas do trofoblasto. Uma das funções do trofoblasto humano é invadir as artérias do miométrio materno durante o primeiro trimestre de gestação e aumentar a capacidade angiogênica por meio de fatores de crescimento, promovendo a vascularização durante o desenvolvimento fetal (LI et al., 2004). O trofoblasto também é capaz de direcionar e auxiliar o remodelamento 
dos vasos para um perfeito desenvolvimento e diferenciação dos vilos na placenta (KAUFMANN et al., 2003).

Fatores angiogênicos presentes nos vilos placentários facilitam a oxigenação e nutrição em gradientes que se estendem para a circulação materna (KAUFMANN et al., 2003) e pelos vilos do trofoblasto promovendo o aumento da circulação fetal e conseqüentemente um maior desenvolvimento do concepto. Este desenvolvimento está associado a um aumento gradativo na produção de oxigênio por volta da $8^{\mathrm{a}}-10^{\mathrm{a}}$ semana de gestação, o que indica o estabelecimento do fluxo sanguíneo no espaço dos intervilos neste período (RODESCH et al., 1992).

Durante o primeiro trimestre de gestação, vilos intermediários imaturos de largo calibre, apresentam lâminas de trofoblasto e também uma complexa rede capilar envolvida centralmente nos vasos (KAUFMANN et al., 2003). O grande aumento das trocas transplacentárias, característico da segunda metade da gestação, depende primariamente do crescimento acentuado de leitos vasculares placentários e do resultante aumento dos fluxos sanguíneos umbilicais e uterinos (REYNOLDS; REDMER, 1995). Um aumento da resistência vascular uterina ou um fluxo sanguíneo uterino diminuído podem ser apontados como precursores de gestações de risco e estão associados com retardo no crescimento fetal (TRUDINGER et al., 1985). Uma vascularização insuficiente também foi apontada como uma das causas da alta taxa de mortalidade embrionária observada em ruminantes durante o terço inicial de gestação (REYNOLDS; REDMER, 1995, 2001).

A densidade vascular placentária é regulada de acordo com a necessidade de aporte sanguíneo para o feto e mesmo para a própria placenta. De um modo geral, a densidade vascular dos tecidos placentários maternos aumenta ao longo da gestação. Em contraste, a densidade vascular dos cotilédones placentários fetais permanece relativamente constante até a metade da gestação, e apenas no terço final da gestação é possível observar um aumento concomitante ao rápido crescimento fetal nesta fase (BARCROFT; BARRON, 1946). Como o desenvolvimento fetal a partir do terço final de 
gestação necessita de maior aporte sanguíneo, fatores angiogênicos aumentam a sua expressão, devido à necessidade da placenta em suprir o crescimento do concepto (BARCROFT; BARRON, 1946).

\subsection{VEGF}

Os principais fatores de crescimento estimuladores do processo angiogênico são o Fator de Crescimento Vascular Endotelial (VEGF), Fator de Crescimento Fibroblastico básico (bFGF), Fator de Crescimento Placentário (PIGF) e Fator de Necrose Tumoral (TNF ) (FOLKMAN, 1995).

VEGFs se ligam a receptores tirosina-quinase de alta afinidade, induzindo a atividade intrínseca enzimática destes receptores (WILLIAMS, 1996): fosforilação dos resíduos de tirosina, bem como de outros substratos das quinases, que estimulam atividades celulares como proliferação, motilidade e diferenciação (PAWSON, 1990).

O fator de crescimento VEGF-A (Vascular Endothelial Growth Factor-A) é o primeiro e melhor descrito membro da família dos VEGFs, que além desta, contém mais quatro proteínas : VEGF-B (OLOFSSON et al., 1996; PAAVONEN et al., 1996), VEGF-C (JOUKOV et al., 1996) VEGF-D e VEGF-E (ACHEN et al., 1998).

Especificamente na placenta, a participação do VEGF como um fator angiogênico foi descrito em suínos (WINTHER et al., 1999), ovinos (BOGIC et al., 2001), humanos (SHARKEY et al., 1993) e bovinos (PFARRER et al., 2005). O VEGF é um mitógeno especifico para células endoteliais, estimulando a proliferação e migração (BERNATCHEZ et al., 1999; DAVIS-SMITH, 1997; DULL et al., 2001; FERRARA et al.,1997; FERRARA, 1999; LANG et al., 2001; SIROIS; SOKER, 1997); além de estar envolvido na modulação da linfogênese normal e anormal nos tecidos (CAO et al., 2004; NAGY et al., 2002). Campos (2005), a partir de estudos com células placentárias bovinas cultivadas sob a influência do VEGF e bFGF descreveu um aumento da produção de progesterona aos 210 dias de gestação, o que sugere ser o VEGF também um agente modulador da função de outras células que não as endoteliais. 
Outros grupos também relataram ser o VEGF capaz de estimular a produção de progesterona por células luteínicas cultivadas (KACZMAREK et al., 2005).

O VEGF induz vasodilatação no caso de hipotensão, o que proporciona uma maior sobrevivência em caso de doenças isquêmicas. Inativação do gene do VEGF em ratos pode resultar em letalidade dos embriões mesmo heterozigotos, além de acarretar retardam o crescimento e desenvolvimentos de anomalias, significativos defeitos na vascularização dos tecidos e órgãos, incluindo a placenta e sistema nervoso (FERRARA; DAVIS-SMITH, 1997). Algumas isoformas do VEGF-A bovino foram identificadas e representadas por 121, 165, 183, 189, e 206 aminoácidos (ROBINSON; STRINGER, 2001, TISCHER et al., 1991) nos humanos foram identificados 6 isoformas representadas por. 121, 145, 165, 183, 189, e 206 aminoácidos (FERRARA, 2001). O VEGF participa também da angiogênese e permeabilidade vascular no período de implantação embrionária (YI et al., 1999), independentemente do peso molecular de suas cinco isoformas (BUSSOLINO et al., 1997). Com o crescimento da vascularização na região interplacentomal, aumentam as ações autocrinas e parácrinas nas células endoteliais induzidas pelo VEGF na placenta bovina (PFARRER et al., 2005).

Estas isoformas são capazes de se ligar a heparina e exercer funções diferentes (HOUCK et al., 1991): as proteínas VEGF 121 e VEGF 165 apresentam funções como modulação e proliferação de células endoteliais envolvidas na angiogênese, já o VEGF $_{189}$ e VEGF 206 apresentam baixa atividade mitogênica, mas induzem a permeabilidade vascular (POLTORAK et al., 1997) de acordo com outros autores a permeabilidade vascular é aplicada para todas as isoformas, já o envolvimento da heparina com as isoformas não surte o mesmo efeito.

Durante a implantação do embrião bovino (18-24 dias) o VEGF foi localizado através de imunohistoquímica nas células do trofoblasto, células gigantes do trofoblasto (TGC) e no tecido uterino (PFARRER et al., 2005), já na região interplacentomal o VEGF foi observado nas (TGC), trofoblasto mononuclear, intercaruncular materno e epitélio glandular (PFARRER et al., 2005). O VEGF em placenta de bovinos clonados aos 270 
dias de gestação e bovinos não clonados ao longo da gestação está localizado no citoplasma das células do epitélio, estroma materno e células do epitélio fetal (CAMPOS, 2005).

Os níveis de mRNA para o VEGF-B, VEGF-C, PIGF não apresentam alterações significativas nas células endoteliais expostas à hipóxia ou anóxia. A proteína quinase ativada pela mitose (Mitogen activated Protein Kinase ou MAP) está envolvida no aumento da expressão do VEGF em situações de hipóxia, o que implica na ativação de um elemento responsivo 'a hipóxia em sua região promotora que responde ao HIF (hypoxia inducible factor) (FORSYTHE et al., 1996; MADAN; CURTIN, 1993; WANG; SEMENZA, 1995; YONEKURA et al., 1999). Uma diminuição nos níveis de oxigênio entre os espaços interplacentomais está relacionada a aumento de expressão dos fatores angiogênicos da família dos VEGFs e FGFs em quantidades significativas para que a produção de vasos seja suficientemente compensatória no caso de déficit tecidual de oxigênio (TODROS et al., 1999).

Além da hipóxia, a expressão do VEGF é regulada pelos estrógenos, como observado no tecido uterino de ratos (CULLINAN-BOVE; KOOS, 1993). Receptores de estrógenos endometriais microvasculares (ER) foram localizados na musculatura lisa vascular dos vasos Foi observada uma alta regulação da expressão do VEGF em ratas e ovelhas submetidas a ovariectomia após o tratamento com estrógeno, o qual favorece o aumento do fluxo sanguíneo e da vascularização uterina (REYNOLDS; REDMER, 2001).

Outros reguladores da expressão gênica do VEGF é o plasminogênio seguido da produção da plasmina, envolvidos na cascata angiogênica (FERRARA; DAVIS-SMITH, 1997). A expressão do sistema VEGF na placenta também pode estar sujeita a variações hormonais, locais ou sistêmicas na dependência da fase gestacional em que o animal se encontra (FERRARA; DAVIS-SMITH, 1997). 
Durante o desenvolvimento embrionário humano, foi detectada expressão do VEGF nas células do trofoblasto da placenta nos primeiros dias após a implantação (BREIER et al., 1992), o que se refletiu em indução do crescimento vascular na placenta decídua e membranas vasculares (FERRARA; DAVIS-SMITH, 1997).

\section{3.1 Receptores para VEGF na placenta}

O VEGF se liga a receptores da família tirosina quinase, o VEGF-A se liga ao receptor VEGFR-1/FIt-1 (Fms-like tyrosine kinase receptor 1) e ao VEGFR-2/KDR (Kinase insert domain containing receptor) segundo De Vries et al. (1992) e Terman et al. (1992). Existe um terceiro receptor, cujos ligantes específicos são VEGF-C e VEGF-D, também denominado de VEGFR-3 ou Flt-4 (YAN et al., 1998). A ativação do Flt-1 pode ser também realizada pelo VEGF-B (OLOFSSON et al., 1998) e o KDR podem ser ativados pelo VEGF-C e VEGF-D (JOUKOV et al., 1996; ACHEN et al., 1998).

Existem 7 domínios tirosina quinase para ambos receptores Flt-1 e KDR na porção extracelular e 1 domínio conservado na porção intracelular (ROBINSON; STRIGER, 2001). O Flt-1 do humano possui 30 éxons e 29 introns, nos bovinos foram identificados 30 éxons e 29 introns localizados no cromossomo 12, podendo existir uma variação de extensão entre os éxons e introns (CURWEN et al., 2004). Para o gene KDR foram encontrados 30 éxons e 29 introns no humano, já nos bovino foram descritos 3 éxons e 2 introns, localizados no cromossomo 6 (CURWEN et al.,.2004).

A presença do VEGF e receptores foram demonstrados nas células da musculatura lisa do útero de ratos através da analise de Northern blot e Hibridização in situ (BROWN et al., 1997). O Flt-1 foi identificado nos vilos da placenta decídua como também nos extravilos do trofoblasto por Charnock-Jones et al. (1994). Os receptores Flt-1 e KDR participam diretamente da regulação da angiogênese, induzindo também diferenciação e transporte celular no lúmen uterino, fluido, epitélio glandular e trofoblasto (WINTHER et al., 1999). Quando o Flt-1 e KDR são ativados pelo VEGF observa-se uma migração celular para o tecido alvo (YOSHIDA et al., 1996). 
Pfarrer et al. (2005) descrevem a imunolocalização do Flt-1 nos bovinos como presente no epitélio luminal no início da gestação (18-30 dias), no glandular em fase subseqüente e na região interplacentomal aos 35-48 dias. O KDR também aparece em ambos os epitélios luminal e glandular além de estar presente nas células do trofoblasto ao longo da gestação nos bovinos (PFARRER et al., 2005).

Em situações de hipóxia ocorre uma competição por parte do fator VEGF-C com VEGFA pelo sítio de ligação do receptor KDR, o que pode levar a um aumento da expressão do receptor, sem reflexos na expressão de VEGF (YONEKURA et al., 1999).

A expressão do mRNA do Flt-1 e do KDR foi localizada nas células do trofoblasto, monócitos, saco vitelino, mesoderma intra embrionário, endocárdio e amplos vasos do endotélio na placenta humana na fase embrionária (SHORE et al., 1997; BROWN et al., 1997). Foi identificada a expressão do receptor KDR no endotélio dos vasos sanguíneos da placenta ovina com 62, 103 e 142 dias de gestação, o receptor Flt-1 não foi detectado nos vasos sanguíneos de ambos os lados materno e fetal da placenta ovina nos três estágios de gestação estudados (BOGIC et al., 2001), o receptor KDR não foi localizado nas células musculares lisas, más sim no epitélio amniótico e nas membranas fetais, já o Flt-1 foi detectado apenas nas membranas fetais dos ovinos (BOGIC et al., 2001).

O Flt-1 participa da regulação da ação do VEGF junto a precursores endoteliais (FONG et al 1995). A expressão do KDR na placenta no começo da gestação é alta e ao decorrer da gestação uma queda na expressão é observada (FERRARA; DAVISSMITH, 1997; JACKSON et al., 1994;), o que aponta para uma diminuição na angiogênese a partir do terço final da gestação. 


\subsection{Corpo Lúteo gestacional bovino}

O corpo lúteo $(\mathrm{CL})$ é um tecido complexo composto por vários tipos celulares que interagem entre si para otimizar o crescimento tecidual e sanguíneo do órgão (SCHAMS; BERISHA et al., 2004). O crescimento do tecido luteínico ou do corpo lúteo depende de novos vasos sanguíneos formados (angiogênese) além de um estabelecimento sanguíneo funcional (BERISHA; SCHAMS., 2005).

A perda de líquido durante a ovulação leva ao colapso do folículo com acúmulo de sangue na área central. Inicia-se a transformação em corpo amarelo (corpo lúteo): as células da granulosa hipertrofiam-se e originam as células luteínicas granulosas ou células luteínicas grandes (LLC); já a teca interna transforma-se em células luteínicas tecais ou células luteínicas pequenas (SLC). Vasos sanguíneos e tecido conjuntivo penetram no CL. A gestação prolonga muito o período funcional do corpo lúteo, cuja regressão ocorre por volta do sexto mês de gestação na espécie humana (DI DIO, 2002). Em bovinos, o corpo lúteo aumenta de tamanho a partir de 2 ou 3 meses de gestação e a regressão tem início por volta de 4 a 6 meses, permanecendo constante até o parto, desaparecendo uma semana após o parto (HAFEZ, 1995).

A principal função do corpo lúteo é a secreção de progesterona que prepara o útero para iniciar e manter a gestação. Modificações no fluxo sanguíneo podem alterar a secreção de progesterona e uma restrição sanguínea no ovário pode ser uma das causas de regressão do corpo lúteo (CUNNINGHAM, 1999). O principal hormônio que estimula a produção de progesterona pelas células luteínicas é o LH a partir de ligação de um receptor especifico localizado na membrana celular (SHAMS; BERISHA, 2004) que ativa mecanismos intracelulares como ativação do cAMP (Adenosina Monofosfato Ciclico) e da PKA (Proteína Kinase Ativada) que conseqüentemente favorecem o aumento da progesterona. 


\subsubsection{VEGF e receptores no corpo lúteo gestacional bovino}

Nos ruminantes os principais fatores angiogênicos que agem no corpo lúteo são caracterizados por se ligarem à heparina e são representados pela família do VEGFs e FGFs (WEBB et al., 2002). No corpo lúteo dos bovinos foram identificadas as isoformas VEGF $_{121}, V$ VGF $_{165}$ e VEGF 189 (BERISHA et al., 2000). Em ovinos as isoformas são representadas pelos VEGF 120, VEGF $_{164}$, VEGF $_{188}$ (REDMER et al., 1996).

O crescimento de novos capilares durante a angiogênese luteínica começa a partir de uma cascata de eventos que inclui trocas na membrana celular, migração e proliferação de células endoteliais e desenvolvimento do lúmen capilar (CAVENDER et al.; 1988). Fatores angiogênicos como VEGF e seus receptores Flt-1 e KDR, importantes para a vasculogênese e angiogênese do CL foram localizados nos fluidos foliculares (PLENDL, 2000).

A expressão do mRNA do VEGF na fase de degeneração do corpo lúteo e na fase luteínica final apresenta um decréscimo quando comparado à fase luteínica inicial e fase luteínica média (BERISHA et al., 2000). O mRNA do Flt-1 tem um aumento da sua expressão no corpo lúteo na espécie humana e bovina no início da fase luteínica média e no corpo lúteo gestacional (FERRARA; DAVIS-SMITH., 1997; BERISHA et al., 2000). Na fase luteínica inicial o Flt-1 e KDR apresentam expressão de mRNA semelhante à fase luteínica média (BERISHA et al., 2000).

A partir da técnica RT-PCR para células da teca e granulosa, observou-se um aumento progressivo na expressão do mRNA do VEGF em resposta à eCG (BARBONI et al., 2000). LH e IGF-1 também se mostraram potentes estimuladores da expressão do mRNA do VEGF, e são capazes de induzir secreção de proteínas nas células luteínicas da granulosa (BERISHA et al., 2005). Segundo Ferrara et al. (1997), a enzima adenosina ciclase é ativada para que aja um aumento da expressão do VEGF induzida pelo $\mathrm{LH}$, já os receptores os receptores Flt-1 e o KDR junto ao VEGF tem a sua regulação induzida pelo processo de hipóxia, durante ciclo estral o Flt-1 não é regulado. 


\subsection{BOVINOS CLONADOS}

A técnica de clonagem tem sido bem sucedida em diversas espécies de mamíferos como nos caprinos, bovinos, suínos e ratos (ZHOU et al., 2000; WILMUT et al., 1997). A eficiência total da técnica, entretanto, permanece baixa porque somente uma porcentagem de $0,5 \%$ à $5 \%$ dos embriões resulta em desenvolvimento à termo. 0 desenvolvimento do blastocisto durante o período de pós-implantação ainda é baixo: apesar de morfologicamente normais, os blastocistos completam seu desenvolvimento como observado em ratos e bovinos (ZHOU et al., 2000).

Grandes placentônios foram relatados em placentas de animais clonados, provavelmente devido ao aumento da vascularização (HEYMAN et al., 2002). As altas taxas de mortalidade fetal e pós-natal dos bovinos clonados estão principalmente associadas a diversas anormalidades cardiopulmonares, estas por sua vez associadas a alterações placentárias (HILL et al., 1999, 2000). As anormalidades placentárias ocorrem com altas incidências tanto no início como no final da gestação e incluem alterações morfológicas do epitélio trofoblástico (HILL et al., 2000), deficiências no estabelecimento da vascularização placentária e diminuição no número de cotilédones (HILL et al., 2000; ALLEN et al., 2003), edema placentário (HILL et al., 1999) e desenvolvimento de hidroalantóide (HEYMAN et al., 2002, HILL et al., 1999). O manejo dos animais parece contribuir para o sucesso ou insucesso da gestação de animais clonados (BHOJWANI et al., 2005).

O sucesso da clonagem depende da reprogramação dentro do núcleo, que induz a expressão de genes nos programas típicos do genoma do zigoto. As principais anormalidades que provocam perdas iniciais e tardias dos animais clonados estão relacionadas a alterações no processo de reprogramação nuclear (KONO, 1998), com conseqüente alteração nos padrões de expressão de determinados genes (NIEMANN et al., 2002). A perda primária associada a deficiências funcionais no começo da placentação dos clones de ovinos e bovinos está correlacionada a defeitos no 
desenvolvimento e vascularização dos tecidos extra-embrionários (BHOJWANI et al., 2005).

Nos mamíferos, a metilação do DNA é essencial para a regulação da transcrição durante o desenvolvimento e diferenciação celular: algumas alterações na metilação são evidenciadas nos animais clonados (WRENZYCKI; NIEMANN, 2003) e estão ligadas a anormalidades na organogênese, o que acarreta altos riscos pré-natais para os clones. Distúrbios na dinâmica da metilação durante o estágio inicial da clonagem (embriogênese), no qual o genoma embrionário é preparado gradualmente para a ativação, contribuem para problemas persistentes no desenvolvimento dos animais clonados (BOURC'HIS et al., 2001). 
4 MATERIAL E MÉTODO 


\section{MATERIAL E MÉTODO}

Foram utilizadas para este experimento, amostras de placentoma, região interplacentomal e corpo lúteo gestacional.

\subsection{COLETA DE MATERIAL}

Para a realização deste trabalho foram coletadas, em abatedouro e após cesarianas, placentomas e região interplacentomal de 24 fêmeas adultas da espécie Bovina (Bos taurus), as quais foram divididas em 5 grupos ( $n=4$ por grupo), 90, 150, 210 e 270 dias de gestação de animais não clonados e 270 dias $(n=8)$ de animais clonados. Placentomas e região interplacentomal adicionais de 45 e 60 dias de gestação também foram analisados. Foram utilizados 12 corpos lúteos divididos em 3 grupos ( $n=4$ por grupo) correspondentes às fases gestacionais de 90, 150, 210 dias. CLs adicionais de 45 e 60 dias de gestação também foram analisados. Como os placentomas de animais de 270 dias de gestação foram obtidos após cesarianas, não foi possivel realizar a coleta dos corpos lúteos desta fase. Para avaliação da idade gestacional, utilizou-se a medida atlanto coccígea do feto (Crown Rump), de acordo com Sloss e Dufty (1980) correlacionando-a a uma tabela que determina à idade gestacional correspondente.

\subsection{ACONDICIONAMENTO DAS AMOSTRAS}

Amostras de $0,5 \mathrm{~cm}^{3}$ de tamanho foram coletadas de placentomas bem como de região interplacentomal e de corpo lúteo. Estas foram imediatamente armazenadas em nitrogênio líquido e mantidas posteriormente em um freezer à $80^{\circ} \mathrm{C}$ até a extração de seu RNA. 


\subsection{PROCEDIMENTOS EXPERIMENTAIS}

Todas estas amostras tiveram seu conteúdo de RNA total extraído no Laboratório de Biologia Molecular do Departamento de Fisiologia da Universidade Estadual Paulista (UNESP), Campus de Botucatu, sob coordenação do Prof. Dr. José Buratini Jr. A extração do RNA total foi realizada a partir do protocolo de Trizol $^{\circledR}$, seguida da transcrição reversa utilizando-se Transcriptase Reversa (Superscript III Invitrogen Carlsbad, CA - USA) para a confecção do cDNA. Após esta etapa buscou-se saber se os cDNAs foram transcritos em perfeitas condições através da amplificação e efetuação de uma corrida em Gel de Agarose a 1,5\% (Invitrogen Carlsbad, CA - USA) utilizando-se GAPDH (housekeeping) como controle da reação. Se o cDNA estivesse em boas condições, posteriormente submeteu-se o mesmo ao PCR em tempo real (Real Time PCR) no aparelho ABIPrism ${ }^{\circledR} 7000$ ou 7500. O início desta etapa foi realizado no Laboratório de Oncologia Experimental do Departamento de Patologia da Faculdade de Medicina Veterinária e Zootecnia da Universidade de São Paulo (FMVZ/USP), sob coordenação da Profa. Dra. Maria Lúcia Zaidan Dagli. Depois de instalado o aparelho ABIPrism ${ }^{\circledR} 7500$ no Laboratório para Estudos Morfofuncionais e Endocrinologia (LEME) do Setor de Anatomia, FMVZ - USP, foi possível a finalização dos experimentos e quantificação relativa da expressão do mRNA do VEGF, Flt-1, KDR normalizados pelo controle endógeno GAPDH.

\subsubsection{Descrição do método de $\operatorname{Trizol}^{\circledR}$ (Invitrogen) para extração do RNA total}

Os tecidos dos placentomas, região interplacentomal e corpo lúteo gestacional foram removidos e transferidos para tubos eppendorf de 1,5 $\mathrm{ml}$ RNase free e armezenados à temperatura de $-80^{\circ} \mathrm{C}$ até análise. Cerca de $40 \mathrm{mg}$ de tecidos foram pesados em gelo e acrescidos de $500 \mu \mathrm{l}$ de Trizol e com o auxílio do aparelho homogenizador de tecidos (POLITRON ou TISSUMIZER) foram homogeneizados. O aparelho homogenizador foi lavado com água DEPC (Dietil 
Pirocarbonato), água RNAse-ZAP (removedor de RNAse) e novamente água DEPC após cada amostra. O homogenato foi armazenado a temperatura ambiente durante 5 minutos. Após este período, $100 \mu \mathrm{l}$ de clorofórmio foram adicionados ( $200 \mu$ l para cada $\mathrm{ml}$ de Trlzol), os tubos foram fechados e agitados vigorosamente por aproximadamente 15 segundos e incubados novamente a temperatura ambiente por 2-3 minutos. As amostras foram centrifugadas por 10 minutos, a $14.000 \mathrm{~g} \mathrm{a} 4^{\circ} \mathrm{C}$.

Enquanto isso, novos tubos foram identificados e acrescidos de $500 \mu \mathrm{l}$ de isopropanol. Após a centrifugação, o sobrenadante foi transferido para os tubos contendo isopropanol, homogeneizados suave e manualmente e incubados a temperatura ambiente por 15 minutos. As amostras foram novamente centrifugadas por 10 minutos, $14.000 \mathrm{~g} \mathrm{a} 4^{\circ} \mathrm{C}$. O sobrenadante foi descartado e $\mathrm{O}$ precipitado (RNA-Total) solubilizado com $1 \mathrm{ml}$ de álcool $75 \%$ diluído em água DEPC. Uma nova centrifugação foi realizada por 5 minutos, $8.000 \mathrm{~g}$ a $4{ }^{\circ} \mathrm{C}$, o excesso de álcool retirado e o precipitado (RNA Total) solubilizado em $200 \mu \mathrm{l}$ de água tratada com DEPC. Uma alíquota foi removida para verificar a integridade do RNA em gel de agarose $1,5 \%$ e para quantificação, e o restante da solução foi armazenado imediatamente em freezer $-80^{\circ} \mathrm{C}$ até sua utilização. A análise qualitativa foi realizada em gel de agarose 1,5\% diluída em TBE 1X. Para tanto, 10 $\mu l$ do RNA total foi acrescido de $1,5 \mu$ do corante Loading Dye (azul de bromofenol, glicerol e agua) 10X e 3,5 $\mu$ água DEPC e a eletroforese foi realizada durante 60 minutos a $80 \mathrm{~W}$.

\subsubsection{Quantificação do RNA total}

Para a quantificação do RNA total as amostras foram diluídas na proporção 1:5, ou seja, $40 \mu \mathrm{l}$ de $\mathrm{H}_{2} \mathrm{O}$ DEPC foi adicionada de $10 \mu \mathrm{l}$ do RNA total e homogeneizada suavemente. A quantificação foi realizada no Biofotômetro 
(Eppendorf) a 260/280nm. Utilizou-se água DEPC para calibração do equipamento.

\subsubsection{Transcrição Reversa (construção da fita de DNA complementar - cDNA)}

Para se assegurar que os resultados são oriundos do mRNA e não do DNA genômico, as amostras foram préviamente tratadas com DNAse $1 \mu$ l (Invitrogen Carlsbad, CA - USA) por 15 minutos em temperatura ambiente.

Aos tubos contendo RNA total ( $1 \mu \mathrm{g}$, préviamente tratados com DNAse I), foram adicionados $1 \mu \mathrm{l}$ do Oligo DT; $1 \mu \mathrm{l}$ de dNTPs (mix $10 \mathrm{mM}-2,5 \mathrm{mM}$ de cada dNTP) e incubados a $65^{\circ} \mathrm{C}$ por 5 minutos, retirados do termociclador e colocados em banho de gelo. A seguir, foram acrescentados aos tubos: $4 \mu$ do buffer $5 \mathrm{X}$ Superscript III ; $2 \mu \mathrm{l}$ de DTT $1 \mathrm{M} ; 1 \mu \mathrm{l}$ de RNAse OUT e esta mistura foi incubada por 2 minutos a $42{ }^{\circ} \mathrm{C}$. A incubação continuou a $42^{\circ} \mathrm{C}$ por 50 minutos e em seguida a $70^{\circ} \mathrm{C}$ por 15 minutos.

Ao término desta incubação foram acrescentados aos tubos $1 \mu$ de enzima RNAse $\mathrm{H}$ (para retirar os resíduos de RNA remanescente na amostra de cDNA) e incubados a $37^{\circ} \mathrm{C}$ por 20 minutos. O cDNA foi armazenado a $-20^{\circ} \mathrm{C}$ até $\mathrm{O}$ momento da amplificação do cDNA em tempo real. Todos os reagentes e enzimas utilizados eram provenientes da (Invitrogen Carlsbad, CA - USA).

\subsubsection{PCR para controle da qualidade do cDNA}

Nesta fase cada tubo recebeu $5 \mu$ l de cDNA, $4,5 \mu$ l de agua e $20 \mu$ l de MIX (Quadro 1) para realização do RT-PCR. Para o controle negativo adiciona-se apenas água sem cDNA. A corrida de RT-PCR para o controle endogeno é de 24 ciclos em 
média, o que pode avaliar a qualidade do cDNA que foi utilizado para quantificação relativa da expressão do sistema VEGF.

\begin{tabular}{|c|c|c|}
\hline \multicolumn{3}{|c|}{ PCR-Gap-Placenta } \\
\hline Reagentes & Por Tubo & MIX \\
\hline PCR Buffer & $\mathbf{2 , 5 0}$ & 8,75 \\
\hline dNTP & $\mathbf{0 , 5 0}$ & 1,75 \\
\hline MgCl2 & $\mathbf{0 , 7 5}$ & 2,63 \\
\hline GAP S 1:10 & $\mathbf{2 , 0 0}$ & 7,00 \\
\hline GAP A 1:10 & $\mathbf{2 , 0 0}$ & 7,00 \\
\hline Taq & $\mathbf{0 , 2 5}$ & 0,88 \\
\hline H2O & --- & 42,00 \\
\hline Vol. final & $\mathbf{2 0 , 0 0}$ & 70,00 \\
\hline Fator de multiplicação & 3,5 \\
\hline Temp anelamento & 60 & oC \\
\hline Ciclos & 24 \\
\hline $\begin{array}{l}\text { Ojetivo: checar GAP em RTs de placentoma, região } \\
\text { interplacentomal e CL }\end{array}$ \\
\hline \multicolumn{2}{|c|}{} \\
\hline
\end{tabular}

Quadro-1 - Mostra o exemplo de uma corrida de RT-PCR qualitativo e os reagentes usados durante a reação para o GAPDH na placenta bovina

\subsection{PCR EM TEMPO REAL NO ABIPRISM ${ }^{\circledR} 7000$ OU 7500 SEQUENCE DETECTION SYSTEMS (APPLIED BIOSYSTEMS)}

Após a transcrição reversa (RT), foi efetuado o PCR em Tempo Real (Real Time PCR) no aparelho ABIPrism ${ }^{\circledR} 7500$ (Figura 2 A). Neste sistema, as fases de anelamento, extensão e desnaturação ocorrem durante os ciclos de maneira similar quando da utilização do termociclador comum, uma vez que o ABIPrism 7000/7500 é um termociclador acoplado a uma câmera CCD (Figura 2 F). A diferença é que a amplificação da seqüência alvo é detectada em tempo real pela emissão de fluorescência, que ocorre quando há formação de dupla fita na região 
codificada pelo par de primers (Figura 2 B, C, D e E). A quantificação relativa da amplificação é feita pela fluorescência captada pela unidade óptica do aparelho (Figura $2 \mathrm{~F}$ ). 

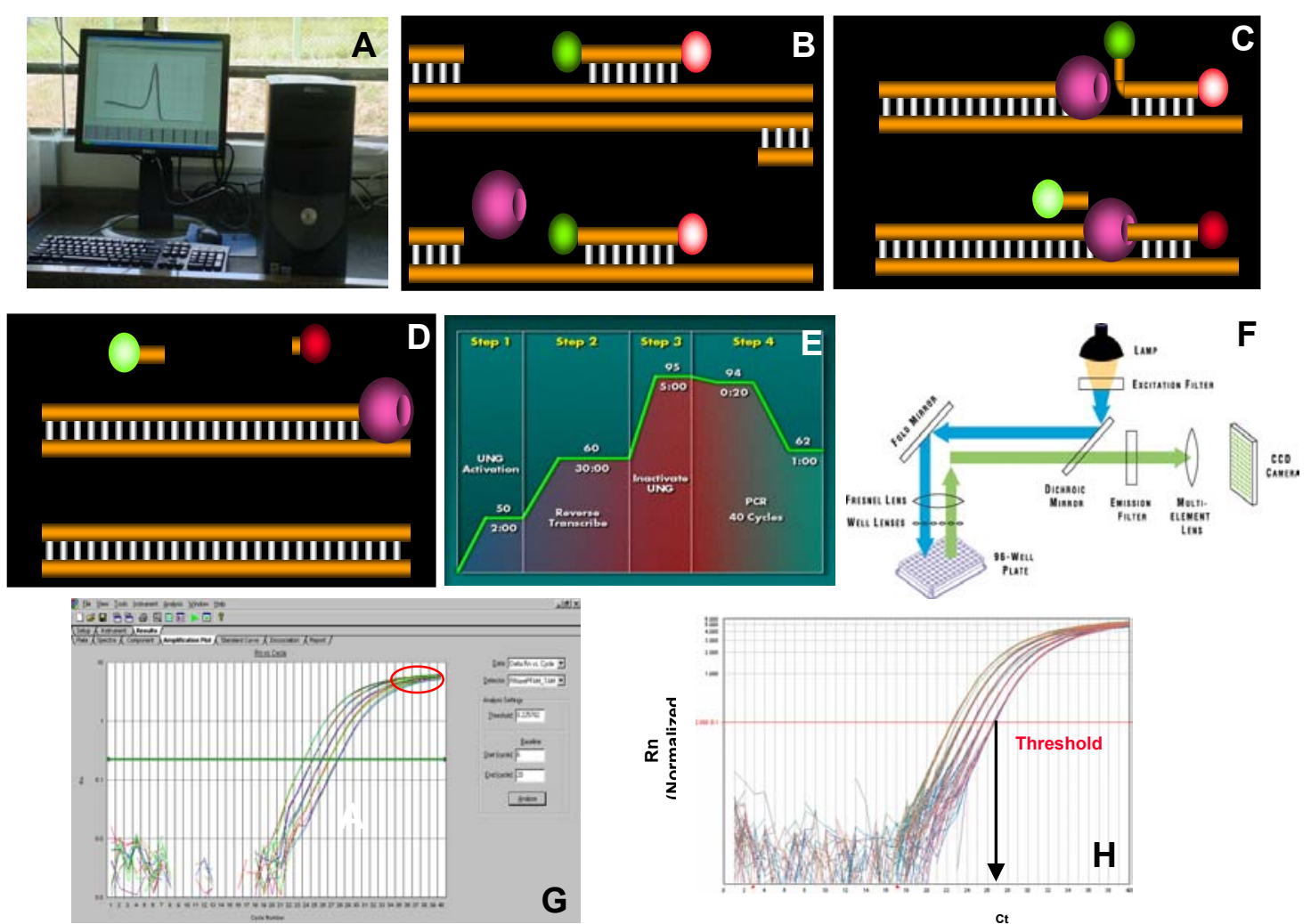

Figura 2 - Esquema geral do PCR em Tempo Real. A. Equipamento ABI Prism ${ }^{\circledR} 7500$. B. Observase os componentes principais da reação em tempo real, os frimers ligados, as sondas ligadas a seus respectivos reporter e quencher e a taq polimerase. Para que não seja amplificado DNA genômico é aconselhado pelo fabricante que os mesmos sejam desenhados em éxons diferentes, embora isto não seja uma regra. C. Início da reação de amplificação, com a extensão dos primers e atividade 5' exonuclease da taq, com liberação do reporter. D. Extensão completa com a liberação completa do reporter. E. Apresentação das etapas do PCR em tempo real. Step 1: ativação da UNG; Step 2: primeira extensão; Step 3: inativação da UNG; Step 4: Desnaturação da dupla fita, ligação da sonda a $70^{\circ} \mathrm{C}$ e dos primers a $60^{\circ} \mathrm{C}$ com extensão dos produtos de PCR. $F$. Funcionamento do sistema óptico de detecção da fluorescência. G. Resultado de uma titulação de PCR. H. Esquema mostrando o limiar de corte, posicionado na fase exponencial e os seus respectivos Cts (número de ciclo). Adaptado de Avanzo (2005). 
À medida que a reação de amplificação se processa (Figura $2 \mathrm{E}$ ), um gráfico é construído (Figura $2 \mathrm{G}$ ). Neste gráfico, a ordenada corresponde ao número de cópias e a abscissa ao número de ciclos. Diferentemente do sistema tradicional de amplificação, onde o que se observa é o número de cópias final (Figura 2 G, círculo vermelho), a amplificação é detectada onde as condições "ótimas" para o PCR são mantidas, ou seja, na fase exponencial. Neste período, os substratos para a amplificação ainda estão presentes nas concentrações ideais, o que no sistema end-point não se observa. Pelas características do sistema, no PCR em tempo real é possível determinar este perfil de amplificação (Figura $2 \mathrm{H}$ ), o que representa uma das vantagens metodológicas. O ponto na abscissa correspondente ao início do trecho linear é chamado de $\mathrm{Ct}$ (cycle threshold = limiar de corte) e este valor é utilizado para a comparação relativa da expressão gênica: quanto menor o Ct, teoricamente mais expressa é determinada mensagem, ou seja, a diferença de $1 \mathrm{Ct}$, representa o dobro de expressão.

O sistema adotado tanto no laboratório de Oncologia Experimental do Departamento de Patologia quanto no LEME do Departamento de Cirurgia, Setor de Anatomia da FMVZ/USP para a detecção da expressão gênica do fator de crescimento VEGF e de seus receptores Flt-1 e KDR foi o sistema TaqMan. Neste sistema, além do par de primers, é necessária a utilização de uma sonda que, por ter um $\mathrm{Tm}$ (temperatura de melting) mais alto (cerca de $10^{\circ} \mathrm{C}$ de diferença), se hibridiza de forma específica com a fita molde de cDNA antes do par de primers. A sonda é composta na sua extremidade 5' por fluoróforo $\mathrm{R}$ (repórter dye, denominado de FAM para os genes VEGF, Flt-1 e KDR) cuja fluorescência, quando a sonda está integra, é capturada pelo Quencher (NFQ) acoplado ao MGB (Minor Groove Binder - que aumenta a Tm). O MGB é a substância que permite a construção da sonda com a diferença de $10^{\circ} \mathrm{C}$ em relação ao primer (Figura $3 \mathrm{~A}$ ). No caso do controle endógeno GAPDH, a sonda foi construída utilizando-se TAMRA como Quencher e VIC como fluoróforo e a sequência de bases é maior (Figura 2) para garantir o aumento da Tm. 
A

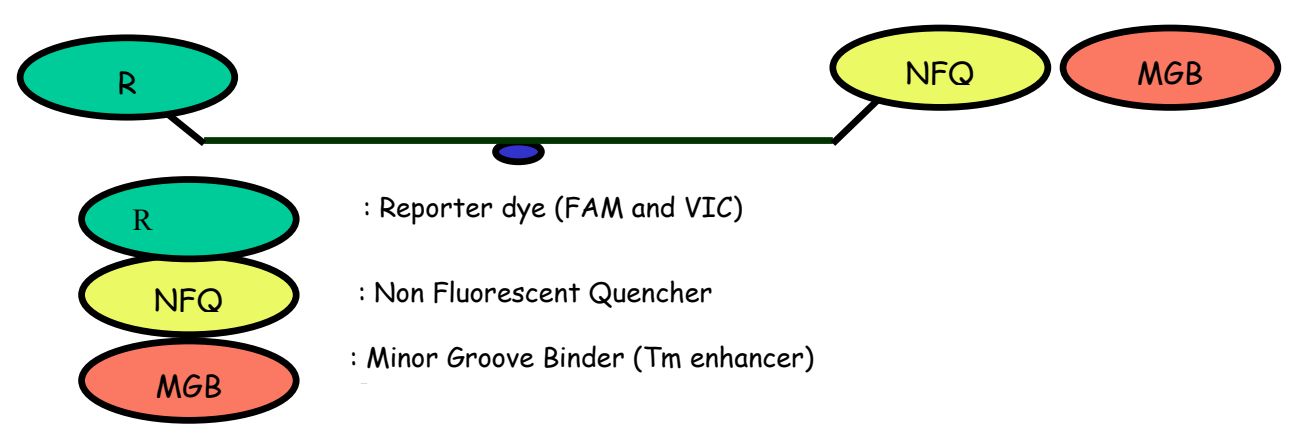

B

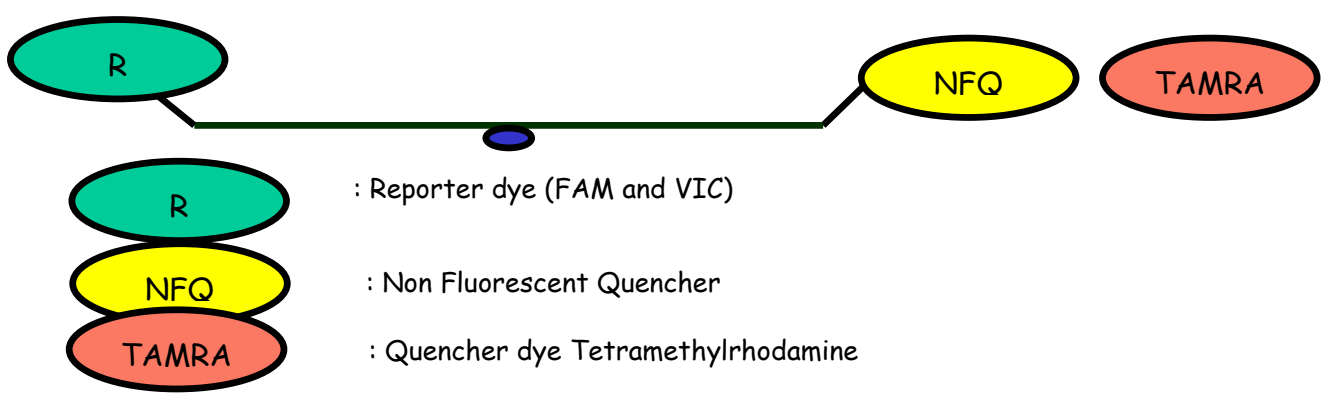

Figura 3 - Esquema representando a sonda fluorescente do sistema TaqMan. Segundo os critérios da Applied Biosystems, o melhor local para a construção da sonda é a junção éxonéxon. Portanto, sempre que possível este critério foi adotado. No entanto, isto é mais indicado quando não se faz o tratamento com DNAse I. Enquanto unidos, a fluorescência emitida pelo repórter é capturada pelo quencher. Durante a reação a probe é clivada ocorrendo a separação do fluoróforo e do quencher. Neste instante a fluorescência emitida é registrada pelo equipamento. MGB ( Minor Groove Binder - Tm enchancer) ou o aumento dos número de bases na sequência aumentam a diferença em $10^{\circ} \mathrm{C}$ em relação aos primers, ou seja, primer $60^{\circ} \mathrm{C}$ de temperatura de anelamento; sonda $70^{\circ} \mathrm{C}$.

Através da atividade corretiva 5' exonuclease da Taq polimerase, o flouróforo é clivado e a fluorescência emitida é captura pela câmera CCD do equipamento. Assim, durante o processo de extensão iniciado pelo par de primers, a sonda se separa da fita molde, e nesse momento ocorre a liberação do fluoróforo. 


\subsubsection{Primers e probes}

As sequências iniciadoras (primers) e as sondas (probe) específicas para as VEGF, Flt-1 e KDR estão descritas no quadro 2. As seqüências utilizadas para a confecção dos primers foram aquelas depositadas no banco público do NCBI (http://www.ncbi.nlm.nih.gov). Para o VEGF, o primer foward (senso) foi desenhado dentro do éxon 3, enquanto que o primer reverse (anti-senso) foi desenhado dentro do éxon 4. Os primers para a sequência Flt-1 foram desenhados dentro do éxon 25 (foward) e dentro do éxon 26 (reverse). Para o KDR, os primers também foram desenhados dentro do éxon 1 (foward) e dentro do éxon 2 (reverse). O GAPDH foi desenhado dentro do exon 9 (foward) e 10 (reverse).

As seqüências enviadas a Applied Biosystems para a construção dos primers estão sublinhadas e discriminadas abaixo.

Para o VEGF os primers foram desenhados dentro dos éxons 3 e 4

VEGF-A bovino (NM_174216)

GTTGGCTGGGCCTGCACACCCTTGCCCCTGCCGCTGCCCATTCTTCGCTCTTTGCTTTGTCCTCAGTGGT CCCAGGCTGCACCCATGGCAGAAGGAGGGCAGAAACCCCACGAAGTGGTGAAGTTCATGGATGTCTACC AGCGCAGCTTCTGCCGTCCCATCGAGACCCTGGTGGACATCTTCCAGGAGTACCCAGATGAGATTGAGTT CATTTTCAAGCCGTCCTGTGTGCCCCTGATGCGGTGCGGGGGCTGCTGTAATGACGAAAGTCTGGAGTG TGTGCCCACTGAGGAGTTCAACATCACCATGCAGATTATGCGGATCAAACCTCACCAAAGCCAGCACATA GGAGAGATGAGCTTCCTACAGCATAACAAATGTGAATGCAGACCAAAGAAAGATAAAGCAAGGCAAGAAA ATCCCTGTGGGCCTTGCTCAGAGCGGAGAAAGCATTTGTTTGTACAAGATCCGCAGACGTGTAAATGTTC CTGCAAAAACACAGACTCGCGTTGCAAGGCGAGGCAGCTTGAGTTAAACGAACGTACTTGCAGATGTGAC AAGCCGAGGCGGTGAGCCGGGCTGGAGGAAGGAGCCTCCCTCAGGGTTTCGGGAACCAGACGTCTCAC CAGGAAAGACTGACACAGAACTACCCATAGCCGCCGCCACCACCACCACACCACCACCACCACCATCGA CAGAACAATCCTGAATCCAGAAACCTGACATGAAGGAAGAGGAGGCTGTGCGCAGAGCACTTTGGGTCC GGAGCGTGAGGCTCCGGCAGAAGCATTCATGGGCGGGTGACCCAGCACGGTTCCTCTTGGAATTGGATT GCCATTTTATTTCTCTTGCTGCTAAATCACCGAGCCCGGAAGATTAGAGAGTTTTATTTCTGGGATTCCTGT AGACACACCCACCCACATACATACATACATTTATATATATATATATATATTATATATATAAAAATAAATATATA TATTTTATATATAT 


\section{Para o Flt-1 os primers foram desenhados dentro dos éxons 25 e 26}

Flt-1 bovino (X94263)

ggatctagttcaggttcaatattaagacatcctgaactgagtttaaaaggcacccggcacgtgatgcaagctggccagacgctgaatctcaa atgcagggtgactgtattggtttggtatctgcctgaagctgtgaacagggaaaaccaaagcgggaagcttaacatcactaagtctgcctgtg gaaagaacctcaagaaattctgcagcactttgaccttgaacgcggctcaggccaaccacactggcttctatagctgcagatatctctctgca cctgcttccaagaacaaagcagaatctaccatctacatatttattaatgatacaggtagacctttcgtagacatgcgcagtgaaatccctaag gttataaatatgaccgaagggaagaaggtggtcatcccctgccgggtctcgtctcccagcatcagtgttactttaaaaaagtttccatctggta ctctgatccccaatggaaaaagaataatctgggacagtaggaggggttttataatacataaagcatcctacagagaagtggggetttgacc tgcgagacaacagtcaacggacatttgtacaagtcaaactatctcataattcggcaaaccaacacaatcacagacgtctggataagcaca ccaggcccagtcagacaactgagaggccatactctcaccctcaactgcacggctaccaccccattgaacacaagagttgagatgacctg gagttaccctggaggagtaaataagagagccagtataaggcaacgcattgaccaacgcaatccccacaataatgtattctacagcatcctt gttattgacaaagtgcagaaggaagaccaagggctttacacttgtcatgtgaaaagcgggcaaacgctcaagtctgttaacacctcggtgc atatatatgacaagggattcatcactatgaggcctcaacagcagcaggcgtttgaggctgtagctggcaagcggtcttaccggctctccatg agagtgaaggcgttccccactccagaagttgtctggttaaaagacgggtcactggccactgagaagtctgcccgctatctgattcgtggctat tcattgattatcaaagatgtgactcccgaagatgcaggggactacacagtcttgctgggcataaagcaggcaaatgtgttcaaaaacttcac tgtcactctgattgtcaatgtgaaaccccagatttacgaaagggctgtatcatcattcccggatccgatcttgtacccactgggcagc agacagatcctgacctgcaccatttatggagtccccacacctgctatcacgtggttctggcacccctgtaaccataatcactccaatgcaagg tataactcttgctccactaatgaagaggcctttatcctggatcctgacagcactgtaggaaacagaattgagagcctcactcagcgcacggc aatcatagaaggaaagaataagacgtctagtaccttggttgtggctgacgctagaatttctggaatctacacttgcatggctaccaataaagt cgggactgtggaaagaaacatgaacttttacatcacagatgtgccccatggatttcatgtgaccttggacaaaatgcctgcggaaggagag gacctgaagctgtcttgcacagtgagcaagttttgtacaaagacataacctggatttgctgcggacagtgaacaaccagaccacgcaac agagcatcagcaagcaaaagacacctgtcacgaaagagcactccnnnnnnnnnnnnnnnnnnnnnnnnnnnnnnnnnnnnnn nnnnnnnnnnnntaggaacatatacacaggggaagaaatcctccagaagaaagaagtgatcattagagatcaggaagcaccctacc tcctgcgaaacctcagtgacctcacggtagccatcagcagttcgacgactctagattgtcatgctaatggtgtcccagagcctcagataacct ggtttaaaaacaaccacaaaatacagcaagaacctggaattattttaggaccgggaagcagcacactgtttatcgagagagtcacggaa gaggatgcaggcgtgtatcactgcaaagccagcaacctgaagggctcggcagagagctcggcccacctcactgtgcaagggacctcgg acaagtccaacctggagctcatcactctgacgtgcacctgtgtggctgcaaccctcttctggctcctgttaacgcttttatccgaaaactgaaa aggtcgtcttctgagattaaagctgactacctgtcaattatcatggacccggatgaagttcccctggatgagcagtgcgatcggctcccttatg atgccagcaagtgggagtttgcccgggagagacttaaactgggcaagtcactcggaagaggggctttcggaaaagtggtgcaagcatcg gcgttcggcatcaagaaatcacccacctgccggactgtggctgtaaagatgctgaaagagggggccacggccagcgagtacaaggctc tgatgaccgagctcaagatcctgacccacatcggccaccatctgaacgtcgtcaacttgctgggagcctgcaccaagcaaggagggecc ctaatggtgattgttgaatactgcaaatatggaaatctctccaactatctcaagagcaaacgggccttattctttctcaacaaggatgcagcctt acacgtggagcctaagaaagaaaaaatggagccagacctggagcagggcgagaaacaaagactagacagcgttaccagcagcga 
gagcttcgcgagctccgggtttcaggaagataaaagtctcagtgatgttgaggaagaggaggattttgacgacttctacaagcagcccatc actatggaagatctgatttcttacagttttcaagtggccagaggcatggagttttgtcctccagaaagtgcattcatcgggacctggccgcacg aaacatacttttgtctgagaacaacgtggtgaagatttgtgactttggccttgcccgggatatttataagaaccccgactatgtgagaaa aggagatacacgacttcctctgaagtggatggctcccgagtccatctttgacaagatctatagcaccaagagcgacgtgtggtcttacgga gtgctgctgtgggagatcttctccttaggtgggtccccctacccgggggtgcagatggacgaggacttctgtagccgcctgaaggacgggat gaggatgcgagcacccgagtatgccacgcctgaaatctaccagaccatgttggactgctggcacaaagacccaaaagaaaggcc aagatttgtggaacttgtggaaaaactaggtgacctgcttcaggccaatgtacaacaggatggtaaagactacattccgctcaacgccat éxon 25 cctgacaggcaacactgcgtttacgtactcgacacctgccttctccgaggacttcttccaggaagatatttctgctccaaagtttaattcaggga gttctgataatgtcagatatgtcaatgctttcaatttcatcagcctggaaaaactcaaaacctttgaagaattctcaccgaatggcacctccctg cttgatgactaccagctggatagtggcaccctgctggcctcccccttgctgaagcgcttcacctgggcagagagcaaacccaaggcccca ctgaactttagcttgagagtaaccagtaagagtaaggagtcaggcctttctgacctcagcagacccacgttttgccacgccagctgtgggca cctgggcgcgggccaccgcaggttcacctatgatcactcggagctggagaggaagatttcctgctgctcacctccgcccgactacaactct gtggtcctgtactccacccaccagtc

\section{Para o KDR os primers foram desenhados dentro dos exons 1 e 2}

Flk-1 bovino (X94298)

agagggacttgcagtggctctggcccaacaatcagagcagctctgagaaaagagtggaggtcacagactgcagtgatggcgtcttctgtaagatgctcac éxon 1

aatttcagaagtgattggaaatgatactggagcctacaagtgcttctaccaggacactgacatgggctccgttcttatgtgtatgttcaagattacaggtctccg éxon 2 tttattgcttctgttagcgaccagcatgaagttgtgtacatcactgagaacaaaaacaaaactgtggtgattccgtgtttggggactgtttcagacctcaatgtgtc actctgtgcaaggtatccagaaaaaagatttgtacctgatggtaacagaatttcctgggacagccagaaaggcttcagtattcccagctatatgatcagttatg ctggcgtggt

\section{Para o GAPDH os primers foram desenhados dentro dos exons 9 e 10}

\section{GAPDH bovino (AB098985)}

tctcttgtccccctcagattcggccgcatcgggcgcctggtcaccagggctgcttttaattctggcaaagtggacatcgtcgccatcaatgacc ccttcattgaccttcactacatggtctacatgttccagtatgattccacccacggcaagttcaacggcacagtcaaggcagagaacgggaag ctcgtcatcaatggaaaggccatcaccatcttccaggagcgagatcctgccaacatcaagtggggtgatgctggtgctgagtatgtggtgga gtccactggggtcttcactaccatggagaaggctggggctcacttgaagggtggcgccaagagggtcatcatctctgcaccttctgccgatg cccccatgtttgtgatgggcgtgaaccacgagaagtataacaacaccctcaagattgtcagcaatgcctcctgcaccaccaactgcttggc ccccctggccaaggtcatccatgaccactttggcatcgtggagggacttatgaccaccgtccacgccatcactgccacccagaagactgtg gatggcccctccgggaagctgtggcgtgacggccgaggggctgcccagaatatcatccctgcttctactggcgctgccaaggecgtgggc aaggtcatccctgagctcaacgggaagctcactggcatggccttccgcgtccccactcccaacgtgtctgttgtggatctgacctgccgcctg gagaaacctgccaagtatgatgagatcaagaaggtggtgaagcaggcgtcagagggccctctcaagggcattctaggctacactgagg 
accaggttgtctcctgcgacttcaacagcgacactcactcttctaccttcgatgctggggetggcattgccetcaacgaccactttgtca

$(\diamond$ forward ; $\vee$ reverse; probe $)$

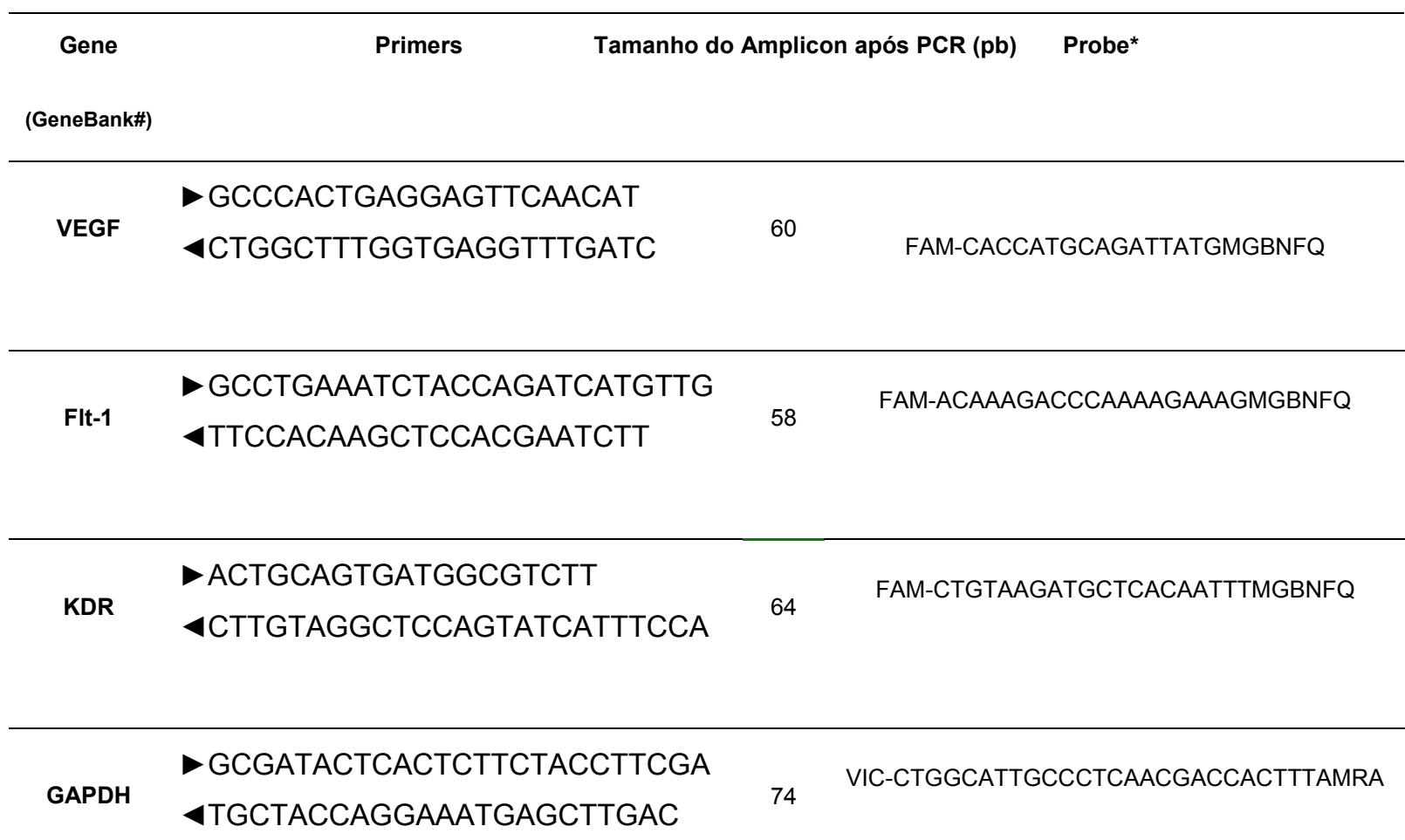

Quadro-2 - Primers, probes e seus respectivos produtos de amplificação

${ }^{*}$ Carcterísticas de monitoramento dos sinais fluorescentes do sistema 7000 ou 7500 gerados durante o PCR pelos fluoróforos $\mathrm{FAM}^{\mathrm{TM}}$, e $\mathrm{VIC}^{\mathrm{TM}}$. = forward; 4 = reverse. Os primers e probes para a VEGF, Flt-1 e KDR foram desenhados pelo serviço Assays-by-Design ${ }^{\text {SM }}$ de expressão gênica (Applied Biosystems); GAPDH foi desenhado pelo Custon Oligo Synthesis Service (Applied Biosystems, Foster City, USA).

\subsection{CONDIÇÕES DA REAÇÃO DE REAL TIME PCR}

A amplificação dos cDNAs do VEGF e seus receptores no equipamento ABI7000/7500 Sequence Detection seguiu os critérios determinados pelo fabricante do aparelho. Assim, a enzima UNG que corrige quaisquer problemas oriundos da transcrição reversa foi ativada por 2 minutos a $50^{\circ} \mathrm{C}$ e desativada por 
10 minutos a $95^{\circ} \mathrm{C}$. A reação da polimerase em cadeia propriamente dita ocorreu durante 40 ciclos, compreendendo 15 segundos à $95^{\circ} \mathrm{C}$ para a desnaturação das fitas de cDNA seguidos de 1 minuto à $60^{\circ} \mathrm{C}$ para extensão. Após este período os dados coletados foram analisados e normalizados com o controle endógeno. As reações foram efetuadas em singleplex, ou seja, o gene do controle endógeno (GAPDH) foi amplificado separadamente dos outros genes.

\begin{tabular}{|l|c|c|c|}
\hline Etapa de PCR & Temperatura $\left({ }^{\circ} \mathrm{C}\right)$ & Tempo & $\mathbf{N}^{\circ}$ de Ciclos \\
\hline $\begin{array}{l}\text { 1 Descontaminação de } \\
\text { carry-over via UNG }\end{array}$ & 50 & 2 min & X 1 ciclo \\
\hline $\begin{array}{l}2 \text { Pré-ativação da DNA } \\
\text { polimerase }\end{array}$ & 95 & 10 min & X 1 ciclo \\
\hline 3 Etapa de desnaturação & 95 & 15 segundos & X 40 ciclos \\
\hline $\begin{array}{l}\text { 4 Etapa de anelamentol } \\
\text { extenção (combinadas) }\end{array}$ & 60 & 1 min & X 40 ciclos \\
\hline
\end{tabular}

\subsection{INTERPRETAÇÃO DOS RESULTADOS OBTIDOS NO SISTEMA DE REAL TIME PCR}

No método comparativo para a expressão relatva de um gene alvo em comparação a um gene de referência, baseado na eficiência dos primers (PFAFFL, 2001), a quantidade do gene alvo é normalizada a um controle endógeno e calculada em relação a um calibrador. 
Formula:

(E target) ${ }^{\wedge} \mathrm{CP}$ target (contol-sample)

(E ref) ${ }^{\wedge} \mathrm{CP}$ ref (contol-sample)

E target $=$ eficiência do gene alvo

E ref $=$ eficiência do gene constitutivo

${ }^{\wedge} \mathrm{CP}$ target $=\mathrm{Ct}$ do controle menos a amostra do gene alvo transcrito

${ }^{\wedge} \mathrm{CP}$ ref $=\mathrm{Ct}$ do controle menos do gene constitutivo transcrito

\subsection{PREPARO DA SOLUÇÃO PARA EFICIÊNCIA DO PRIMER (GAPDH)}

Os primers senso e antisenso do GAPDH foram diluídos de acordo com a especificação do fabricante. Para tanto, o conteúdo dos tubos foi precipitado e ressuspenso em $100 \mu \mathrm{l}$ de TE para homogeneização das amostras, seguido de vortex por alguns segundos, para a total homogeneização. Dois eppendorfs foram utilizados para diluir o conteúdo da solução de estoque $(100 \mu \mathrm{M}): 18 \mu \mathrm{l}$ da solução de estoque foram acrescidos de $82 \mu \mathrm{l}$ de TE para cada um dos primers Forward e Reverse, resultando em uma solução a $10 \mu \mathrm{M}$.

Para a dissolução da sonda fluorescente o mesmo critério de diluição foi adotado. À quantidade sintetizada $(60 \mu \mathrm{l})$ foram adicionados $1140 \mu \mathrm{l}$ de TE. A solução resultante foi alíquotada em 10 eppendorfs contendo $120 \mu$ l cada (foram envoltos em papel alumínio para evitar a luz, impedindo assim a degradação da sonda). A concentração final obtida na reação equivale a $900 \mu \mathrm{M}$ de cada primer e $250 \mu \mathrm{M}$ de sonda. Estas mesmas concentrações são utilizadas para primers e sondas quando sintetizados pelo sistema Assay by Design ${ }^{\circledR}$ da Applied Biosystems. 


\subsection{AVALIAÇÃO DA EFICIÊNCIA DOS PRIMERS UTILIZADOS}

A eficiência dos primers é testada para determinar se os pares de primers possuem eficiência próxima de $100 \%$, ou seja, duplicar o produto de PCR a cada ciclo de reação. O valor da eficiência pode variar $10 \%$ para mais ou para menos (90-110\%) que a eficiência será considerada 100\% (Quadro 4), que uma vez confirmada pode-se utilizar o cálculo da expressão relativa (PFAFFL, 2001).

Para se calcular a eficiência utiliza-se a inclinação da reta diretamente na fórmula abaixo:

$$
E=10^{(-1 / \text {-slope })-1 * 100}
$$

\begin{tabular}{cc}
\hline VEGF & $93 \%$ \\
GAP & $92 \%$ \\
Flt1 & $107 \%$ \\
KDR & $104 \%$ \\
\hline
\end{tabular}

Quadro-4 - Valores de eficiência de cada primer utilizado nos experimentos

Foram utilizadas diluições: $1 / 2,1 / 4,1 / 8,1 / 16,1 / 32$. A diluição $1 / 8$ foi escolhida como padrão para todas as corridas de PCR em tempo real realizada com as amostras de VEGF, FIt1, KDR e GAPDH.

\subsection{ANÁLISE ESTATÍSTICA DOS RESULTADOS}

Os valores obtidos para a expressão gênica relativa do sistema VEGF no placentoma, região interplacentomal e corpo lúteo gestacional de bovinos foram transformados em logarítimo na base 10 e então submetidos à análise estatística. Utilizou-se o programa SAS e os testes ANOVA e $\mathrm{t}$ de Student quando comparadas as expressões relativas ao longo da gestação e as diferenças entre o grupo de animais clonados e não clonados a termo, respectivamente. 
5 RESULTADOS 


\section{$5 \quad$ RESULTADOS}

Foi possível quantificar o mRNA do sistema VEGF ao longo da gestação dos bovinos tanto na placenta quanto no corpo lúteo. Na placenta foram observados tanto região interplacentomal quanto placentomas em relação à expressão deste sistema. Além da expressão fisiológica ao longo da gestação, quantificou-se a expressão do VEGF e seus receptores em placentomas de animais clonados aos 270 dias de gestação e estes resultados foram comparados aos obtidos para animais não clonados. Variações temporais de expressão foram observadas, o que enfatiza a importância destes fatores na vasculogênese e angiogênese da interface materno-fetal e do corpo lúteo gestacional.

\subsection{EXPRESSÃO DO VEGF, Flt-1 E KDR NO PLACENTOMA BOVINO}

Nossos resultados mostraram que a expressão relativa do VEGF no placentoma é semelhante nos períodos de 60, 90, 150 e 210 dias de gestação. No entanto, um decréscimo ( $p$ < 0.05) foi observado ao final da gestação (270 dias) em relação à expressão do VEGF aos 90 dias (Figura 4 A - Apêndice A). A expressão aos 45 dias de gestação parece ser menor do que em outras fases estudadas, mas a quantidade reduzida de amostras de mesma fase não permitiu que este grupo fosse analisado estatisticamente. A expressão do receptor Flt-1 apresentou-se semelhante à do VEGF, no entanto, nenhuma expressão foi detectada com 40 ciclos na amostra de placentoma de 45 dias. Não houve diferença significativa de expressão entre as diversas fases estudadas (Figura 4 B - Apêndice). 
A

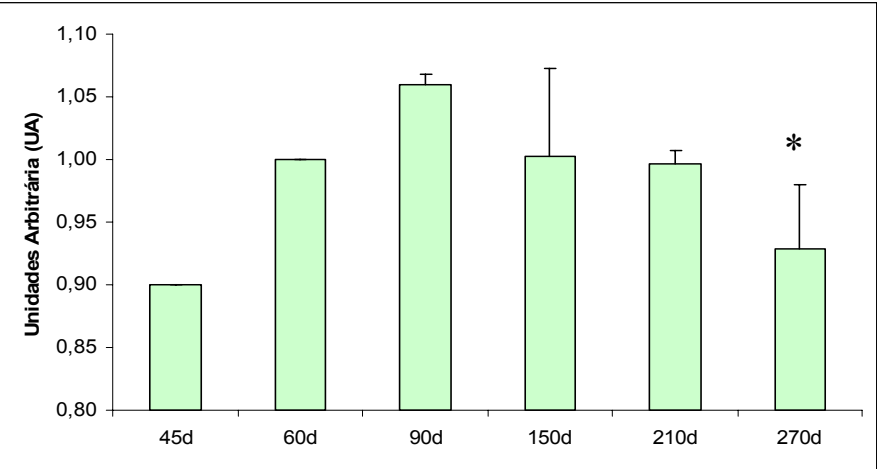

B

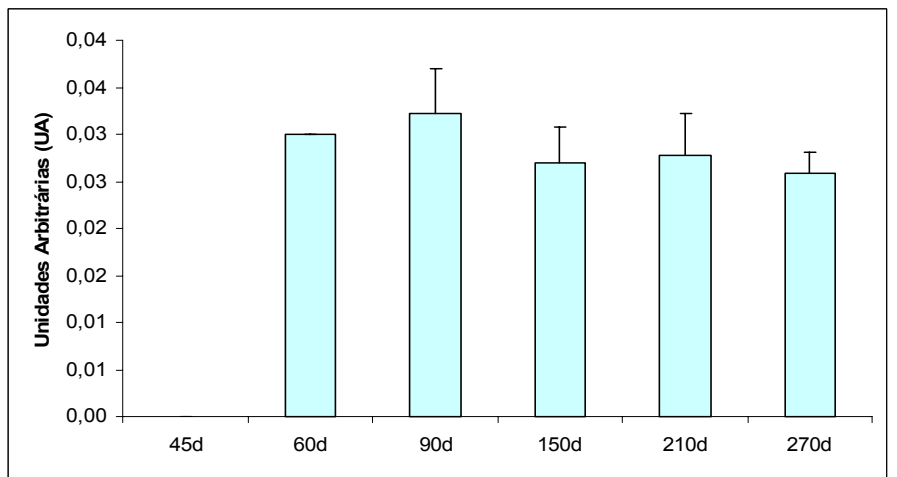

C

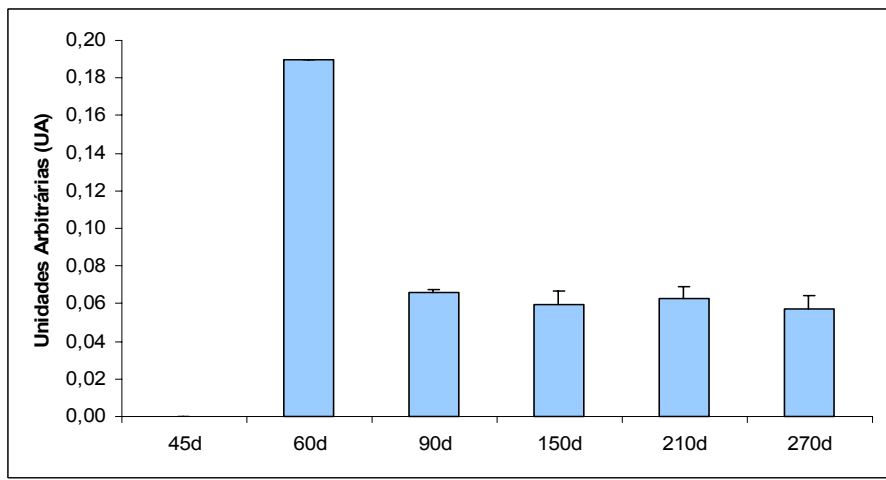

Figura 4 - Expressão relativa do mRNA do VEGF(A), FIt-1 (B) e KDR (C) em placentoma bovino em diferentes idades gestacionais. Os dados obtidos por PCR em tempo real foram normalizados ao GADPH. Os resultados representam média \pm desvio padrão de 4 observações por grupo (90 a 270 dias) ou uma observação (45 e 60 dias). * $p<0.05$ vs. 90 
A expressão relativa do KDR não variou ao longo do período estudado apesar da amostra de 60 dias de gestação ter apresentado uma expressão relativa três vezes maior do que as outras fases. Como descrito para o Flt-1, a amostra de 45 dias não apresentou expressão de KDR nas condições utilizadas de PCR em tempo real (Figura $4 \mathrm{C}$ - Apêndice $\mathrm{C}$ ).

Os placentomas aos 270 dias de gestação dos grupos de clonados e não clonados não mostraram diferenças de expressão para o sistema VEGF (Figura 5 - Apêndice D, E, F). Placentomas de fetos fêmeas e de fetos machos foram designados de grupos 2 e 3, respectivamente, quando foram comparados ao grupo de placentomas de animais não clonados (grupo 1). Em conjunto (Figura 6 ) ou separadamente (Figura 7) não foi possível observar diferenças entre os grupos para a expressão dos três genes estudados.

A expressão relativa média do VEGF apresentou tendência a ser maior no grupo 3 (fetos machos clonados), principalmente devido à expressão do VEGF no animal de número 3.5 (Figura 7A). A Figura 7 apresenta os dados obtidos para cada animal, clonados ou não clonados, aos 270 dias de gestação para a expressão do sistema VEGF. Observa-se também que placentomas do bezerro "Independência" apresentou menor expressão relativa dos receptores Flt-1 e KDR em relação aos outros animais do mesmo grupo (Figura 7 B e C). 
A

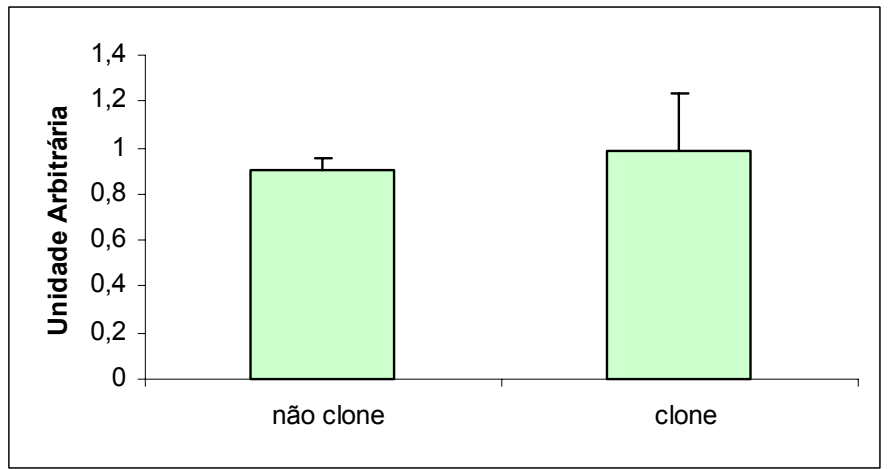

B

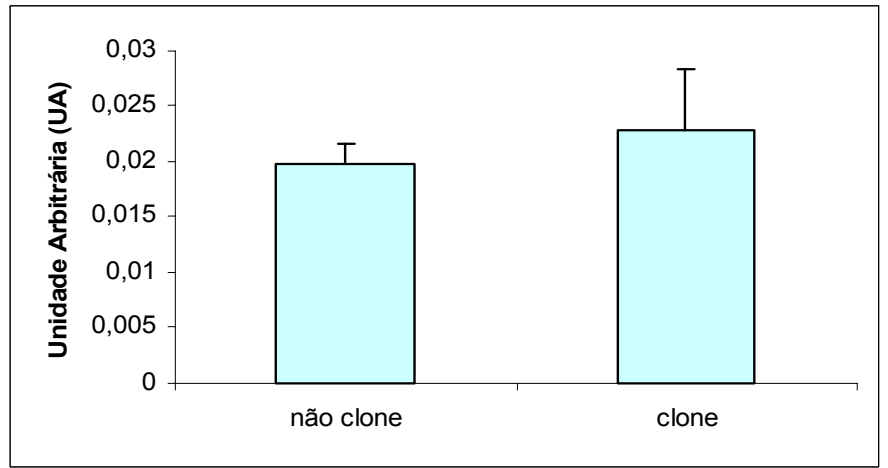

C

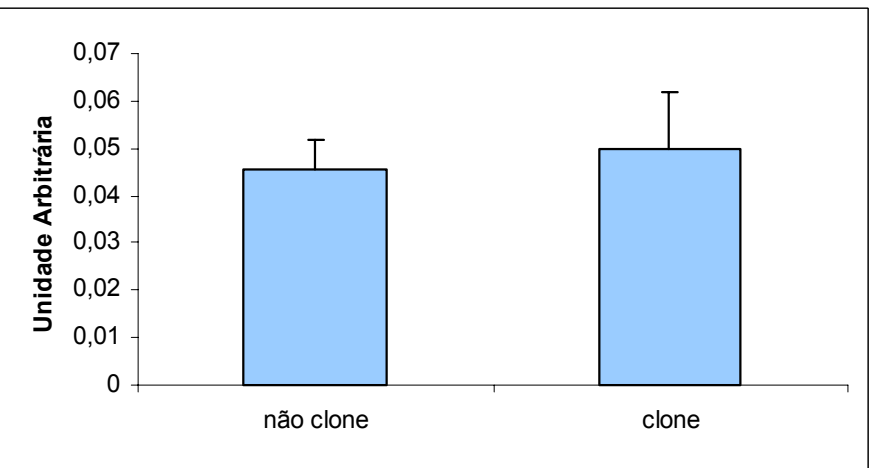

Figura 5 - Expressão relativa do mRNA do VEGF(A), Flt-1 (B) e KDR (C) em placentoma bovino aos 270 dias de gestação de clones e de fetos não manipulados. Os dados obtidos por PCR em tempo real foram normalizados ao GADPH. Os resultados representam média \pm desvio padrão de 4 e 8 observações para não clone e clone, respectivamente 
A

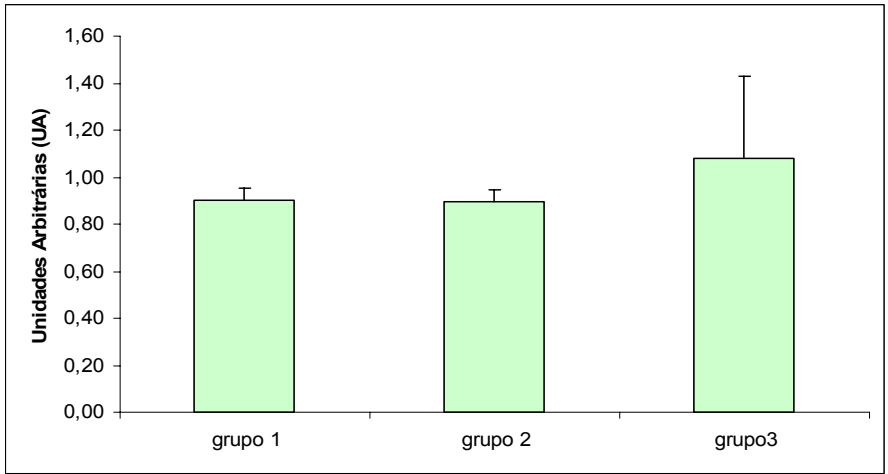

B

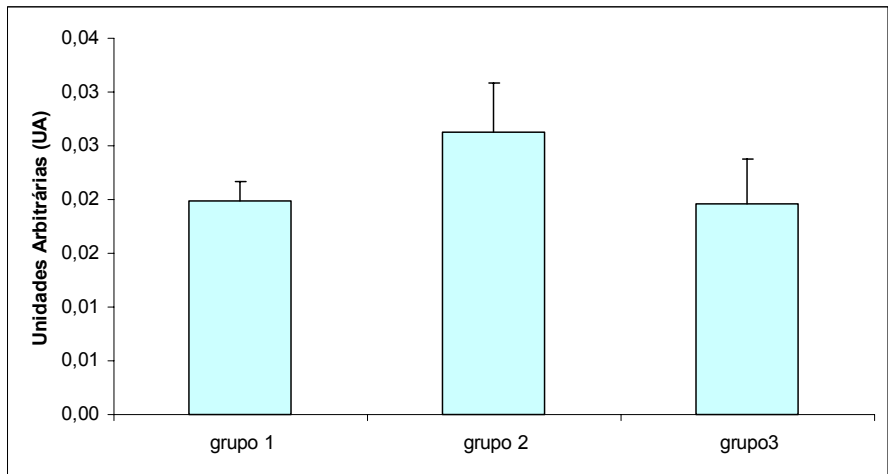

C

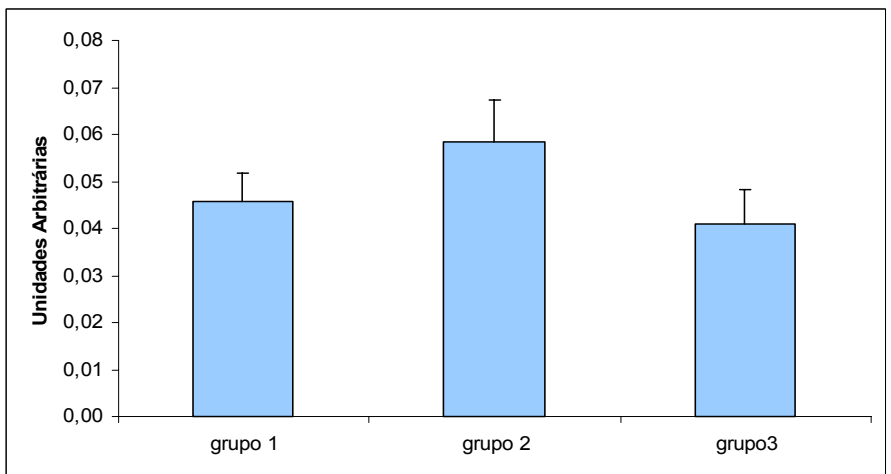

Figura 6 - Expressão relativa do mRNA do $\operatorname{VEGF(A),~Flt-1~(B)~e~KDR~(C)~em~placentoma~bovino~}$ aos 270 dias de gestação. Os dados obtidos por PCR em tempo real foram normalizados ao GADPH. Os resultados representam média \pm desvio padrão de 4 observações por grupo 
A

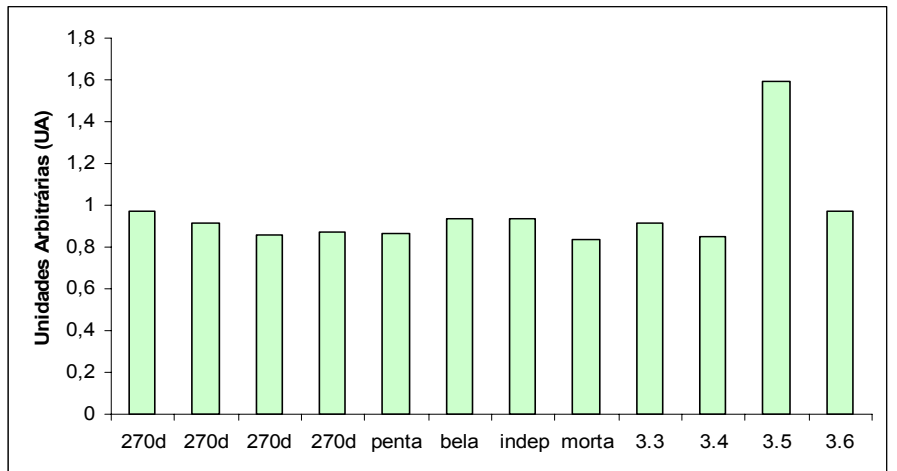

B

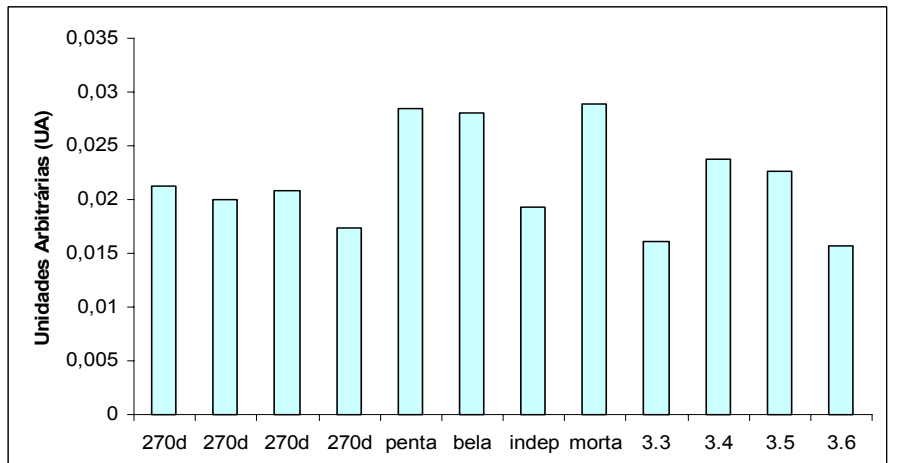

C

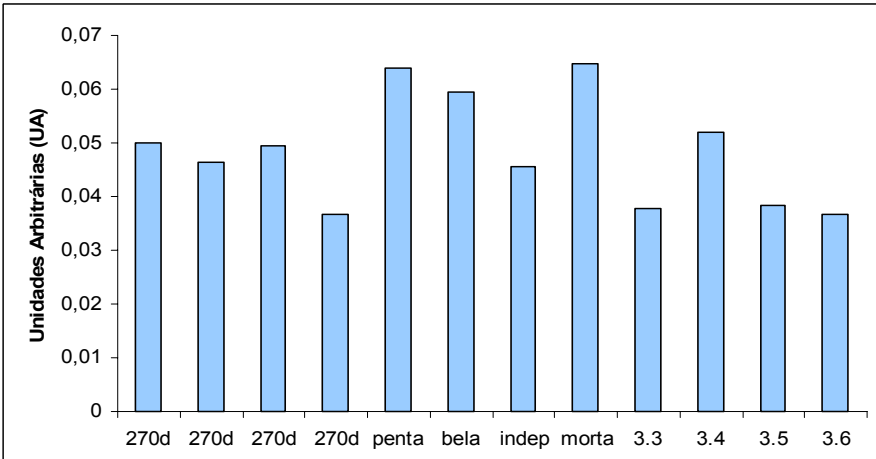

Figura 7 - Expressão relativa do mRNA do $\operatorname{VEGF(A),~Flt-1~(B)~e~KDR~(C)~em~placentoma~bovino~}$ aos 270 dias de gestação. Os dados obtidos por PCR em tempo real foram normalizados ao GADPH. Os resultados representam expressão individual nas amostras de animais não clonados (270d) e de animais clonados (nomes ou números) 


\subsection{EXPRESSÃO DO VEGF, FLT-1 E KDR NA REGIÃO INTERPLACENTOMAL}

Os resultados referentes à expressão do VEGF, Flt-1 e KDR na região interplacentomal são apresentados na figura 8. Nestes resultados nós comparamos a expressão de 45, 60, 90, 150, 210 e 270 dias.

Não se observou diferença na expressão temporal relativa do VEGF na região interplacentomal nos períodos gestacionais estudados. Quando avaliada a expressão aos 270 dias verificou-se que a esta expressão parece maior em relação às demais fases (Figura $8 \mathrm{~A}$ - Apêndice $G$ ), no entanto, o número reduzido de observações neste grupo $(n=1)$ não permitiu uma confirmação estatística deste dado.

A expressão do Flt-1 apresentou expressão semelhante dos 45 aos 90 dias de gestação seguida por aumento significativo $(p<0.05)$ aos 150 dias. A expressão manteve-se elevada até 210 dias de gestação e depois é reduzida enormemente aos 270 dias (Figura 8 B - Apêndice H). Neste caso a amostra de região inteplacentomal foi testada duas vezes para a expressão do Flt-1 e apresentou o mesmo resultado: ausência de produto de amplificação nas condições de PCR utilizadas. Por se tratar de apenas uma amostra, a confirmação deste resultado também não foi possível.

A expressão do KDR na região interplacentomal apresentou-se semelhante à do receptor Flt-1: existe uma expressão semelhante até 90 dias de gestação e aumento significativo $(\mathrm{p}<0.05)$ da mesma aos 150 dias, o qual se mantém até 210 dias de gestação e tende a diminuir novamente aos 270 dias (Figura 8 C Apêndice I). Entretanto, aos 270 dias de gestação, o número reduzido de indivíduos observados $(n=1)$ impediu que resultados mais consistentes fossem alcançados. 
A

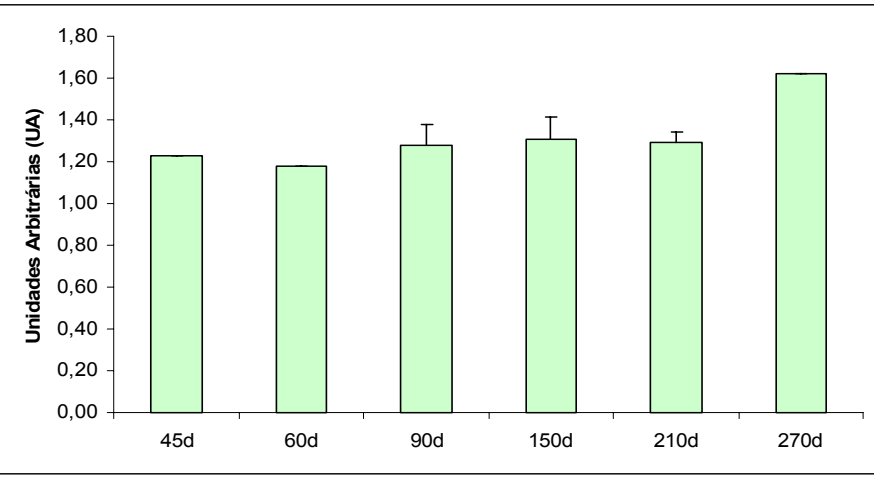

B

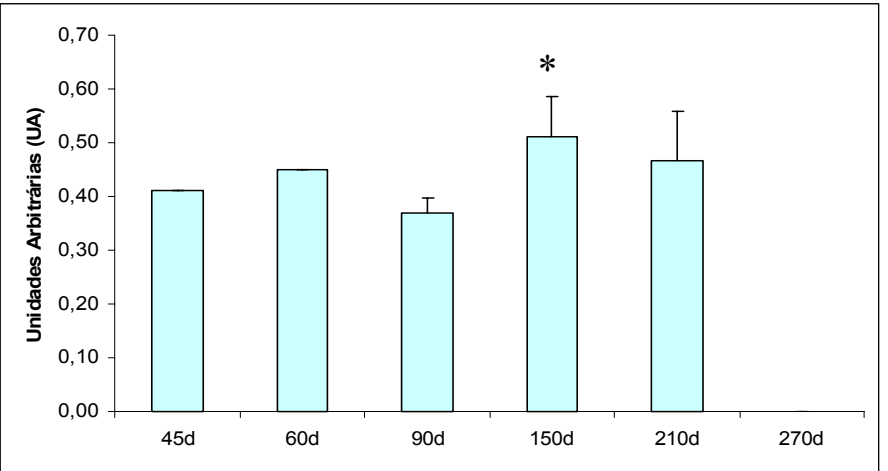

C

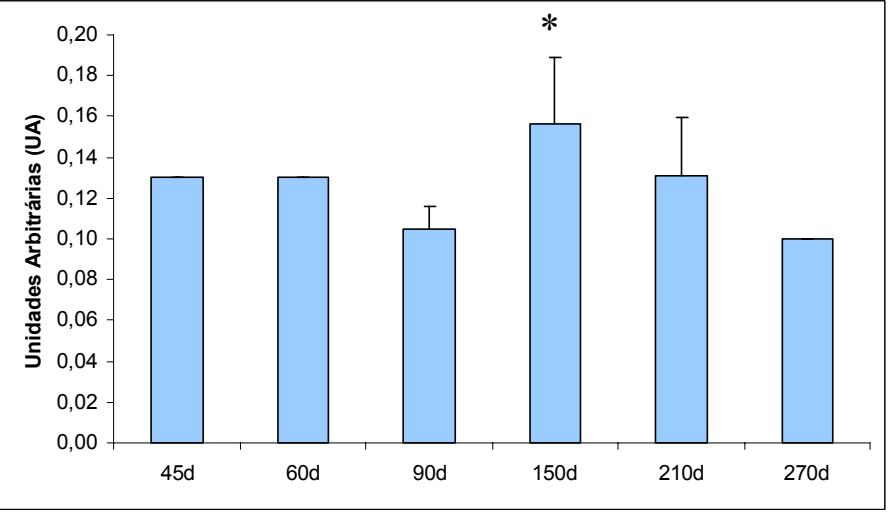

Figura 8 - Expressão relativa do mRNA do VEGF e receptores na região interplacentomal em diferentes fases gestacionais. Os dados obtidos por PCR em tempo real foram normalizados ao GADPH. Os resultados representam média \pm desvio padrão de 4 observações por grupo (90 a 210 dias) ou uma observação (45, 60 e 270 dias). * p $\leq$ 0.05 vs. 90 


\subsection{EXPRESSÃO DO VEGF, FLT-1 E KDR NO CORPO LÚTEO GESTACIONAL}

Os resultados referentes à expressão do VEGF, Flt-1 e KDR no corpo lúteo gestacional são apresentados na figura 9. Amostras de 45, 60, 90, 150 e 210 dias de gestação foram comparadas entre si. Verificou-se que a expressão do VEGF aos 210 dias é maior $(\mathrm{p} \leq 0.05)$ do que nas fases de 90 e 150 (Figura 9 A Apêndice J). As fases de 45 e 60 dias não puderam ser consideradas na análise estatística devido ao número pequeno $(n=1)$ de observações.

A expressão do Flt-1 no corpo lúteo gestacional apresentou-se peculiar: observouse um pico de expressão aos 90 dias em relação às demais idades gestacionais estudadas (45, 60, 150 e 210 dias de gestação). No entanto, o grande desvio padrão observado contribuiu para que este dado não pudesse ser comprovado estatisticamente (Figura 9 B - Apêndice K).

Ao contrário do Flt-1, a expressão do KDR no corpo lúteo gestacional apresentouse mais baixa exatamente aos 90 dias de gestação $(p<0.05$ em relação aos 210 dias). O número de amostras colhidas nas fases de 45 e 60 dias não permitiu a aplicação das ferramentas estatísticas para se verificar se a diferença observada é significativa (Figura 9 C - Apêndice L). 
A

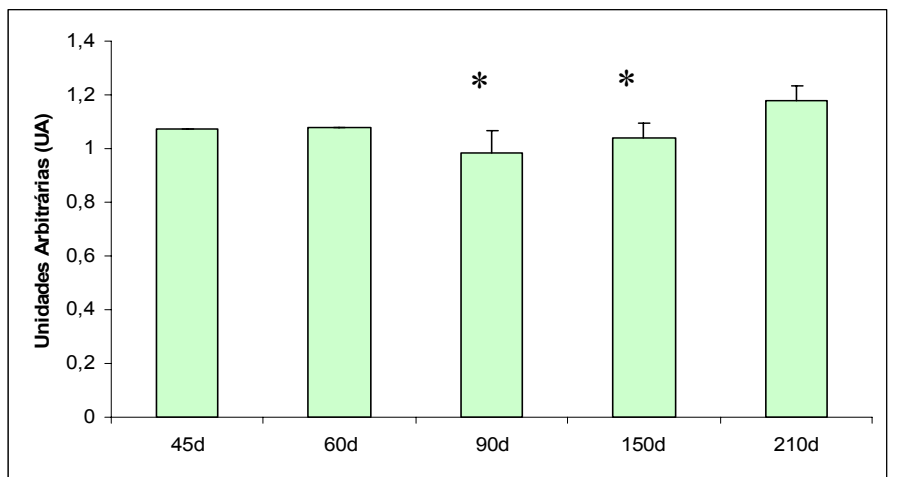

B

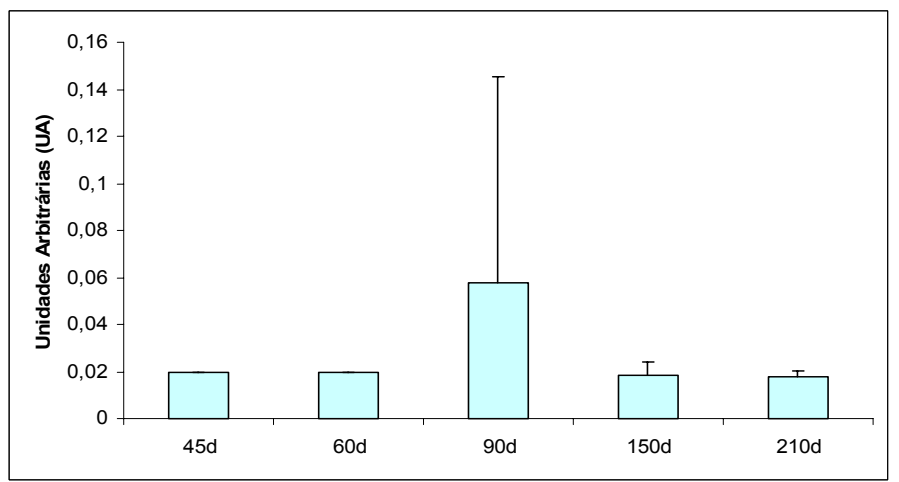

C

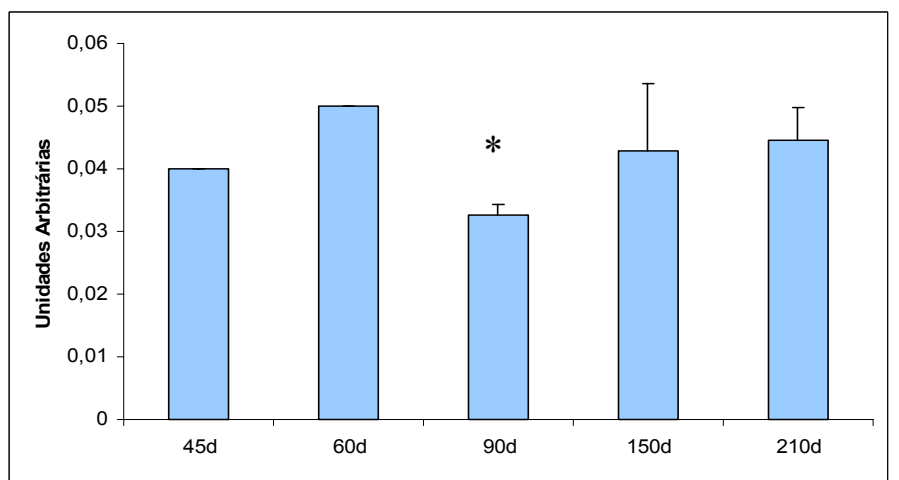

Figura 9 - Expressão relativa do mRNA do VEGF e receptores no corpo lúteo gestacional em diferentes fases gestacionais. Os dados obtidos por PCR em tempo real foram normalizados ao GADPH. Os resultados representam média \pm desvio padrão de 4 observações por grupo (90 a 210 dias) ou uma observação (45 e 60 dias). * $p \leq 0.05$ vs. 210 
6 DISCUSSÃO 


\section{DISCUSSÃO}

A expressão temporal do mRNA do sistema VEGF neste trabalho vem esclarecer melhor as diferenças de expressão em relação à possíveis alterações na sua regulação na placenta, de acordo com os períodos gestacionais de 45, 60, 90, 150, 210 e 270 dias. Com o intuito de apresentar dados originais, sem referência até o presente momento na literatura, foram escolhidas e analisadas amostras do placentoma, região interplacentomal e corpo lúteo gestacional. Além disso, a expressão do sistema VEGF nas amostras de placentoma de 270 dias de gestação foram comparadas com os bovinos clonados na busca de diferenças que pudessem embasar as falhas de vascularização já descritas em placentas de animais geneticamente modificados. O corpo lúteo gestacional para este estudo foi analisado a partir de 45 até 210 dias de gestação, apresentando-se inviável a coleta de amostras aos 270 dias.

O desenvolvimento vascular da placenta tem como origem comum a vasculogênese controlada por fatores angiogênicos (ZYGMUNT et al., 2003). A regulação molecular da angiogênese na placenta é dirigida pelos fatores angiogênicos, incluindo o VEGF e FGF (CHARNOK JONES et al., 2004; ZYGMUNT et al., 2003).

Os padrões de angiogênese no feto e na placenta não somente variam durante o curso de uma gestação normal, como observado neste trabalho, mas também de acordo com patologias relacionadas à gestação, como hipóxia, préeclampsia, deficiência de ferro e diabetes (MAYHEW et al., 2003). O VEGF foi estudado em nível protéico em função de sua expressão na placenta de bovinos durante o desenvolvimento embrionário (PFARRER et al., 2005). Um aumento da expressão do VEGF no terço final de gestação foi observado nas células do epitélio uterino e epitélio coriônico da placenta suína (FORD et al., 2001). Na placenta de caprinos foi localizado o VEGF associado aos vilos fetais e maternos no epitélio amniótico, não sendo detectado no citotrofoblasto e no estroma (BOGIC et al., 2001) diferente de Pfarrer et al. (2005) que identificaram 
o sistema VEGF no epitélio e estroma maternos, epitélio fetal e também em células endoteliais da placenta bovina.

Nossos resultados mostraram diminuição significativa $(p<0.05)$ da expressão do VEGF ao final da gestação (270 dias) em relação à expressão do VEGF aos 90 dias, o que justifica o aumento da expressão do VEGF no primeiro trimestre de gestação seguido de uma queda próxima ao parto. De fato, aos 150 dias foi observado um desvio alto de expressão entre as amostras, o que não permitiu comparar esta fase com final da gestação. Através dos nossos resultados o VEGF mostrou-se peculiar em relação à expressão com tendência à diminuição dos níveis no final de gestação. A densidade vascular placentária é regulada de acordo com a necessidade do aporte sangüíneo para que o feto e a placenta possam se manter no útero até o final da gestação (REYNOLDS et al., 2004). Uma vez formado o leito vascular placentário, fase na qual a expressão do VEGF encontra-se mais elevada, a manutenção do mesmo para o aporte sanguíneo necessário não requer uma expressão elevada do fator.

No placentoma existe uma co-localização do VEGF com o VEGFR-1 durante a implantação dos embriões bovinos, o que indica uma interação entre eles (PFARRER et al., 2005). O Flt-1 atua como um sinalizador regulado para o controle da proliferação de células endoteliais durante a angiogênese, já o KDR contribui predominantemente na migração e proliferação das células endoteliais para manutenção dos vasos sanguíneos (BUSSOLATI et al., 2001).

Durante os primeiros 45 dias de gestação houve grande dificuldade para análise da expressão relativa do Flt-1 e KDR no placentoma através da técnica de PCR em tempo real. Não foi detectada expressão dos receptores (Flt-1 e KDR) neste período. Foi questionada a presença do VEGF no estágio embrionário, uma vez que não haveria ligante para este fator. Procuraram-se dados mais confiáveis para que fosse embasada a capacidade do fator VEGF em manter sua expressão sem seus próprios receptores no início da gestação. Presume-se que o VEGF possa ser auto-regulado através de mecanismos autócrinos, e também através de outros receptores ainda não citados anteriormente na literatura, o que explicaria uma ausência parcial e baixa da 
expressão dos receptores Flt-1 e KDR aos 45 dias de gestação. De acordo com Tseng et al. (2004) a expressão do Flt-1 aumentado nos vilos do trofoblasto é regulada a partir de mecanismos autócrinos, enquanto que a expressão de VEGF e de KDR aumentada dentro dos recipientes de vilos placentários é regulada através de mecanismos parácrinos. É possível que a atividade funcional do VEGF possa ser dependente do seu próprio nível de expressão, o que implicaria em armazenamento de mRNA no tecido placentário inicialmente sem haver necessidade de expressão dos receptores Flt-1 e KDR nesta fase.

De acordo com Pfarrer et al. (2005) os receptores Flt-1 e KDR estão presentes no endotélio dos vasos sanguíneos da placenta durante toda a gestação, principalmente durante a pré-implantação nas células do trofoblasto e epitélio uterino no estágio embrionário nos bovinos. Em nosso estudo foi verificada uma tendência de aumento de expressão do mRNA do KDR, a qual foi observada primeiramente aos 60 dias de gestação, enfatizando a importância do receptor para a proliferação de vasos neste período. Diferenças no perfil de expressão entre o mRNA e a proteína foram relatadas para o sistema VEGF: alterações no padrão de liberação da proteína e mesmo de ancoragem das mesmas na matriz extracelular foram descritas (PUNYADEERA et al., 2006), o que reflete mecanismos regulatórios diversos para a transcrição e a traduação.

Outra hipótese para a baixa regulação de expressão do Flt-1 e KDR na placenta com 45 dias de gestação, seria a pequena quantidade de vasos formados, uma vez que os placentomas nesta fase ainda são muito pequenos. Não foi possível comparar a ausência de expressão devido à escassa quantidade de amostras coletadas nos períodos de 45 e 60 dias de gestação, fato que não permitiu realização de análise estatística.

A interação entre o VEGF e o Flt-1 no início da gestação (90 dias) evidencia que a recíproca entre o VEGF e KDR é importante para manter a integridade do fluxo sanguíneo durante toda a gestação. A maior expressão do KDR no primeiro trimestre de gestação aconteceu aos 60 dias e foi seguida por uma queda da expressão a partir dos 90 dias. Observou-se expressão semelhante 
do KDR aos 150, 210 e 270 dias de gestação, enfatizando seu papel como receptor responsável pela manutenção do leito vascular (BUSSOLATI et al., 2001). Provavelmente, o crescimento inicial da placenta depende de sua habilidade no desenvolvimento de vasos, que crescem junto com a proliferação e diferenciação do trofoblasto e do endotélio materno ( $L I$ et al., 2004). Assim, propomos que o KDR seja mais ativo na placenta dos bovinos após a formação do leito vascular. O trabalho de Pfarrer et al. (2005) demonstrou a presença do KDR nas áreas de crescimento dos placentomas, o que sustenta a sua importância no crescimento das carúnculas maternas nos bovinos.

Os constituintes da família do VEGF estão envolvidos na disfunção placentária, bem como na vascularização insuficiente da placenta como contribuinte da morte embrionária durante a fase inicial da gestação e mesmo no aumento da resistência vascular na placenta (REYNOLDS; REDMER, 2001).

Segundo o trabalho de Vonnahme e Ford (2004), no final de gestação de suínos ocorre um aumento da expressão do VEGF. Algumas das variações na eficiência placentária dos suínos estão associadas à densidade vascular placentária e endometrial correlacionadas com o sistema VEGF (VONNAHME; FORD, 2004). Já nos bovinos, não encontramos aumento significativo da expressão do VEGF aos 270 dias, ao contrário, observamos uma diminuição. A diferença entre o arranjo, forma e classificação da placenta dos suínos com relação aos bovinos podem acarretar diferenças de expressão do VEGF no final de gestação observadas até o momento.

Os fatores que afetam o desenvolvimento vascular placentário têm um impacto grande na função da placenta, crescimento e desenvolvimento fetal. Em contrapartida alguns hormônios associados à manutenção da gestação estão intimamente relacionados a fatores de crescimento vascular como o sistema VEGF na placenta (ZYGMUNT et al., 2002).

De acordo com Ancelin et al. (2001) o fator de permeabilidade vascular, in vivo, mostra a isoforma 189 como indutora da permeabilidade capilar. Estas observações demonstram que a progesterona regula a expressão da isoforma 
189 do VEGF nas células da decídua. Como um tecido que exibe mudanças cíclicas freqüentemente, o endométrio humano é um modelo bom para o estudo fisiológico da angiogênese. Alguns autores sugerem que a progesterona, por sua ação em células da decídua, module a permeabilidade vascular necessária para implantação e possivelmente para a manutenção da gravidez (ANCELIN et al., 2001).

Células de origem materna produzem baixas concentrações de progesterona até os 80 dias de gestação, um aumento é observado aos 90 e 135 dias de gestação (IZHAR; PASMANIK; SHEMESH, 1992). Foi demonstrado que o fator de crescimento VEGF está envolvido na modulação da produção de progesterona pelas células placentárias bovinas, dependendo da fase gestacional em que se encontra (CAMPOS, 2005). Aos 270 dias de gestação uma produção baixa de progesterona foi observada. A partir deste estudo realizado por Campos (2005) pode-se sugerir que o VEGF e seus receptores sigam uma correlação de expressão com o nível de progesterona produzido pelas células placentárias, o que justificaria também a queda de expressão do sistema VEGF aos 270 dias de gestação observada neste estudo.

A angiogênese é um processo complexo no qual o equilíbrio de agonistas e antagonistas dirige $\mathrm{o}$ crescimento, diferenciação, sobrevivência e remodelamento das células endoteliais (BERGERS et al., 2003). Durante a gestação normal, a expressão de VEGF e seus receptores no trofoblasto regula também a secreção de uma gama de proteínas e hormônios placentários (TSENG et al., 2004).

O nosso estudo procurou mostrar um dos fatores relacionado à eficiência da placenta bovina nos animais clonados no final de gestação comparando aos animais não clonados, ou seja, o grupo controle em relação ao desempenho dos vascularização neste período gestacional. A técnica de clonagem tem como função aumentar o número de espécimes para conservação do potencial genético desejado, seguida de aplicações que incluem a conservação e preservação de raças e espécies em extinção (RYDER, 2002). O estudo e aplicabilidade de células somáticas na transferência nuclear (TN) vêm 
crescendo muito. Desta forma esta tecnologia oferece o desenvolvimento de mamíferos com muitos benefícios para pesquisa, biomedicina e agricultura, além de promover um caminho para a modificação genética em bovinos, favorecendo a indústria farmacêutica (RAVELICH et al., 2004).

Os animais clonados apresentam algumas diferenças fisiológicas e patológicas em diferentes órgãos, além dos problemas relacionados à reprodução. É visto que a perda primária associada a deficiências funcionais no começo da placentação dos clones de ovinos e bovinos está relacionada aos defeitos no desenvolvimento da vascularização dos tecidos extra-embrionários (BHOJWANI et al., 2005). Como não foi possível coletar amostras de placentomas em diferentes fases gestacionais de animais clonados, nosso trabalho procurou quantificar a expressão do VEGF e receptores apenas no final de gestação, aos 270 dias. Os resultados foram comparados ao grupo de animais "controle" de bovinos não clonados. Segundo Campos (2005), os receptores Flt-1 e KDR não estão presentes em células dos estromas materno e fetal aos 270 dias de gestação em animais não clonados e clonados, ou seja são iguais. Diferenças na expressão do fator VEGF também podem estar influenciando a função placentária (CAMPOS, 2005) ainda neste trabalho as relações a progesterona produzida pelas células placentárias bovinas de animais clonados não foi inferior aos animais não clonados no mesmo período gestacional. No presente, estudo entre os valores de expressão do VEGF e receptores não mostrou diferença quando comparados com o grupo não clonado, o que indica a mesma proporção de vasos formados nos animais não clonados e clonados, tanto machos e fêmeas, nestes animais que chegaram a termo estudos realizados por Lacerda (2006) o peso dos placentomas dos clones foi maior do que os animais não clonados, já o peso fetal não foi significativo quando comparado entre os animais clonados e não clonados. Ainda, no trabalho de Lacerda (2006) foi relatado o volume da placenta dos animais clonados e não clonados, não havendo diferenças significativas Se o peso dos placentomas de animais clonados é efetiva maior do que em animais não clonados, basta corrigirmos a quantidade de expressão do VEGF e seus receptores encontrada por $\mu \mathrm{g} / \mathrm{RNA}$ pelo peso do tecido utilizado para extração e então multiplicarmos pelo peso inicial do placentoma. Obteremos o valor de 
expressão total do sistema VEGF no placentoma, o que pode indicar diferenças de quantidade total entre os animais clonados e não clonados a termo. No entanto, vale ressaltar que se as amostras obtidas de animais clonados são provenientes de animais clonados que vieram a termo, exclui-se a possibilidade de grandes diferenças ou anormalidades vasculares estarem presentes. Portanto na maioria dos estudos com animais clonados percebemos que uma semelhança entre não clonados, em relação à eficiência placentária é observada, entretanto os animais clonados estão próximos de serem totalmente normais.

Grandes placentomas foram relatados em placentas de animais clonados, provavelmente devido ao aumento da vascularização (ALLEN et al., 2003; HEYMAN et al., 2002). Um fator compensatório pode estar correlacionado a este processo. Os animais clonados têm um número menor de placentomas formados com tamanhos gigantes, ou seja, estes placentomas se fundem uns aos outros. Embora os animais não clonados apresentem uma quantidade maior de placentomas em tamanhos normais, esta proporção de tamanho e quantidade entre os animais clonados e não clonados compensa a diferença de vascularização materno-fetal sem levar em consideração as alterações anatômicas.

Foi possível visualizar a variação individual na expressão do VEGF entre as amostras de clones estudadas. Uma das amostras de clone, identificada como "independência" apresentou uma porcentagem alta da expressão de Flt-1 e KDR comparada aos outros animais do mesmo grupo. Um dos estimuladores mais potentes da expressão de VEGF é o fator de hipóxia local. Particularmente o oxigênio se torna limitado com aceleração do crescimento fetal, e um aumento da regulação da síntese e secreção do VEGF é compensada no tecido através do aumento na angiogênese e permeabilidade vascular (FORD et al e VONNAHME et al., 2004). Sabe-se que um ambiente relativo de hipóxia promove o desenvolvimento placentário durante a gestação. No entanto, em ambiente de hipóxia elevada pode determinar complicações irreversíveis. O bezerro clonado "independência" veia a óbito pouco depois do 
nascimento, o gene pode estar embasado por este mecanismo desregulado intra-placentário.

Podemos sugerir neste estudo a possibilidade de os animais precisarem de maior aporte sanguíneo para compensar o mecanismo de hipóxia na placenta mediante de déficit de oxigênio, resultando em grande problema observado nos animais clonados. Em situações de hipóxia ocorre um aumento de expressão do VEGF (FORD et al., 2001). Estas alterações podem estar relacionadas ao processo de reprogramação nuclear, correlacionada a uma expressão aumentada, diminuída ou totalmente oculta na placenta (NIEMANN et al., 2002).

Baseado em alguns autores, propôs-se que os fetos e as placentas resultantes dos embriões produzidos in vitro nos estudos observados por Bertolini; Anderson (2002) seriam mais pesados do que em embriões produzidos in vivo (controle). Comparados com as placentas produzidas in vivo, com as placentas do grupo in vitro mostraram uma diminuição da área de contato materno-fetal, fato observado quando medida a área de superfície do placentoma e a densidade e volume dos vilos fetais.

Em contraste, as placentas do grupo in vitro apresentaram um volume proporcional aumentado de vasos sangüíneos nas carúnculas maternas quando comparadas aos animais in vivo (BERTOLINI; ANDERSON, 2002). Estas observações sugerem que as placentas resultantes de embriões manipulados possam ter desenvolvido algum tipo de mecanismo de compensação em suas camadas vasculares com intuito de melhorar ou aumentar a área diminuída disponível para o contato materno fetal.

Condições imunológicas alteradas nas gestações observadas de animais clonados passa a ser um fator contribuinte para estas perdas embrionárias. Alguns autores propõem um papel de rejeição imunológica seguida de uma síndrome de perda embrionária em gestações de bovinos clonados (JONATHAN et al., 2002). 
De acordo com dados da literatura a gestação de cabras clonadas não apresenta o mesmo padrão de perdas no primeiro trimestre, como vistas em outros ruminantes. No primeiro trimestre de gestação nos bovinos e nos embriões ovinos, uma grande variedade morfológica de placentas foi ilustrada com variações pertinentes ao desenvolvimento epitelial dos cotilédones e do alantóide fetal. Esta vascularização desordenada foi associada ao desenvolvimento de fetos com crescimento retardado e pequeno porte para a sua idade, morfologicamente anormais (JONATHAN et al., 2002).

Embora as principais perdas aconteçam durante os primeiros 14 dias após a transferência dos blastocistos de clones, a causa primária da perda fetal subseqüente parece estar associada com deficiências placentárias funcionais. Anormalidades na placenta de bovinos e ovinos após a transferência de embriões clonados foram documentadas recentemente agregadas a alterações como aumentos umbilicais, membranas edematosas e aumento na quantidade de fluido alantóideano. As causas dessas normalidades permanecem desconhecidas para os autores (RAVELICH et al., 2004).

Nossos resultados de expressão do VEGF corroboram com a hipótese de que alguns genes, como o VEGF, apresentam regulação aumentada ou diminuída, dependendo do problema que o animal apresenta. O fluxo do sangue dentro da placenta é aumentado pela angiogênese, um processo regulado pelo VEGF (CHARNOCK-JONES et al., 2005). Estas constatações, revelam que o mRNA para $O$ VEGF expressa-se no placentoma de animais clonados em quantidades bem semelhantes aos animais não clonados (controles) no final de gestação, portanto não obtivemos alterações na angiogenêse placentária no final da gestação. Entretanto, é possível que o mRNA e a proteína do VEGF possam estar alterados em outros períodos gestacionais, principalmente no início da gestação na placenta de bovinos clonados, ainda não estudados.

No presente estudo foi identificada a expressão do sistema VEGF na região interplacentomal do bovino. Estas regiões fazem a comunicação entre os placentomas por meio de uma ampla rede de vasos, facilitando o transporte de nutrientes e oxigênio na placenta. Quando comparado aos períodos referentes 
a 45, 60, 90, 150 e 210 dias de gestação, notou-se uma produção maior de VEGF aos 270 dias. Levando-se em consideração que foi coletada apenas uma amostra de 270 dias, não sendo possível apresentar dados estatísticos reais para esta idade gestacional. No entanto, este padrão de expressão pode ser considerado o oposto ao observado para o placentoma.

No terço final de gestação, a exigência sanguínea é maior, acompanhado de uma grande formação de vilos cotiledonários formados nesta fase, comparado ao terço inicial e médio de gestação, nos quais os vasos se encontram limitados em numero de células nos tecidos cotiledonários (CARVALHO, 2004).

Com relação à expressão, Flt-1 e KDR demonstraram baixos níveis aos 90 dias, seguido de um aumento significativo $(p<0.05)$ aos 150 dias. Com 270 dias não se observou expressão do FIt-1, entretanto, o KDR apresentou-se expresso nesta fase, o que pode embasar diferentes ações entre receptores em relação a idade gestacional que o animal se encontra. Estudos demonstraram ausência do Flt-1 na placenta da espécie caprina ao final da gestação (BOGIC et al., 2001). Já o KDR aparece como um mediador do VEGF, além de manter a micro-vascularização durante toda a gestação, regulando a capacidade de troca sanguínea entre mãe e feto (BOGIC et al., 2001).

O VEGF e seus receptores foram co-localizados dentro dos epitélios maternos e fetais nas áreas interplacentomais bovinas. O Flt-1 e o KDR mostraram-se expressos no endotélio fetal e materno (PFARRER et al., 2005). Como uma parte da nutrição fetal ocorre dentro dos placentomas, outras funções podem estar correlacionadas ao VEGF na região interplacentomal. Foi sugerido que na área interplacentomal o VEGF possua um papel autócrino e parácrino como regulador epitelial materno-fetal em relação à capacidade de transporte celular na placenta bovina (PFARRER et al., 2005).

Foram obtidos dados de análises e a expressão do gene VEGF, Flt-1 e KDR dentro do corpo lúteo gestacional bovino. A expressão do sistema VEGF foi comparada com intuito de identificar possíveis alterações na expressão do 
VEGF e seus receptores nos diferentes períodos gestacionais que correspondem a 45, 60, 90, 150 e 210 dias da gestação.

Embora o efeito de expressão do VEGF na angiogênese epitelial do ovário possua uma grande ligação com células cancerígenas, muitas perguntas ainda não abordadas na literatura estão sendo exploradas através da técnica de PCR em tempo real, em função do método ser o mais preciso e sensível para a quantificação de expressão gênica (HATA et al., 2004). A relação da expressão do VEGF com a utilização de PCR em tempo real quantitativo corrobora com uma nova ferramenta de diagnóstico para selecionar parâmetros já estudados na fisiologia do corpo lúteo gestacional.

Através deste trabalho buscou-se apresentar dados em relação à vascularização do corpo lúteo gestacional mostrando a importância da proliferação de vasos até o último trimestre de gestação. Estudos Hata et al. (2004) demonstraram que um aumento da expressão gênica através de RTPCR possibilita identificar uma regulação do VEGF no ovário.

Berisha et al., 2002; Toshiaki et al. (2001) enfatizaram a expressão do mRNA do VEGF na fase de degeneração do corpo lúteo, ou seja, na fase luteínica final. Foi identificada uma baixa expressão do VEGF quando comparado às fases inicial e média. No corpo lúteo gestacional, o recente trabalho proporcionou dados de expressão relativamente alta do VEGF $(p \leq 0.05)$ aos 210 dias comparando-os às fases de 90 e 150 dias. Esta proporção de expressão do VEGF no final de gestação e na fase luteínica final no corpo lúteo pode estar ligada a atividades hormonais relacionadas à produção de progesterona, já que esta tem como função manter a gestação e o corpo lúteo até parto. Um aumento dos fatores angiogênicos foi observado após uma reação inflamatória na fase de regressão do corpo lúteo, período característico de maior concentração de VEGF (REDMER et al., 2001). Não foi estudada a expressão do sistema VEGF no CL de termo (270 dias), mas supõem-se que esta estaria diminuída em relação aos 210 dias. 
A expressão dos receptores Flt-1 e KDR mostraram-se aumentados pelo estímulo do estradiol durante a fase média de gestação, proporcionando uma atividade maior de angiogênese e de permeabilidade vascular (KASHIDA et al., 2001). O estradiol pode ativar o sistema VEGF no corpo lúteo de rato durante a fase média de gestação (FRASER; LUNN, 2001). Em nosso estudo foram observados aumentos da expressão próximo da metade da gestação. Com 150 dias o VEGF e o KDR apresentaram-se elevados, enquanto que o mesmo não ocorreu com o Flt-1 seguido de uma queda da expressão aos 150 dias, o que não condiz com Kashida et al; Fraser e Lunn (2001) na fase média de gestação em ratos. Este fato pode estar ligado a diferenças de expressão do VEGF, FIt-1 e KDR associadas ao tempo de gestação e quantidade de secreção de hormônios esteróides presente nos mamíferos domésticos, se comparada à dos roedores.

Considerando-se que a expressão do VEGF no epitélio glandular e do estroma esteja suprimida notavelmente depois de ovariectomia em primatas, alguns autores como Niklaus et al. (2002) mostraram a proliferação deste fator angiogênico com as células endometriais possivelmente dependentes de produtos sintetizados pelo próprio ovário. Além disso, a expressão do VEGF permaneceu relativamente constante ao longo do ciclo estral, promovendo uma vascularização progressiva e reconstrução do endométrio uterino (NIKLAUS et al., 2002).

Estudos relacionados à endocrinologia evidenciaram que além dos hormônios endócrinos principais $\mathrm{LH}$ e $\mathrm{GH}$, reguladores locais, como fatores de crescimento, peptídeos, esteróides e prostaglândinas apresentam-se como moduladores importantes na função do corpo lúteo (SCHAMS; BERISHA, 2004). O LH e o IGF-1 são estimuladores potentes de VEGF a partir da secreção de células da granulosa bovina. Este aumento reflete-se no desenvolvimento do corpo lúteo cíclico e na importância da angiogênese no corpo lúteo gestacional (SCHAMS; BERISHA, 2004). Segundo a literatura o estrógeno modula a expressão do VEGF (NAKAGAWA; FUJIMOTO; TAMAYA et al., 2004). 
Neuvians et al. (2004) relataram que o sistema VEGF e o sistema FGF, são regulados durante o desenvolvimento do corpo lúteo bovino. No $\mathrm{CL}$ bovino, a expressão para VEGF e KDR aparecem aumentadas na fase luteínica inicial, entretanto o Flt-1 não é regulado durante o ciclo estral, como descrito por alguns autores. Já o VEGF tem pico de expressão dentro do $C L$ maduro e durante a gravidez. Foi visto que o VEGF não apenas participa da angiogênese más também mantém a sobrevivência de células endoteliais (NEUVIANS et al., 2004). Embora ocorra um aumento de expressão do VEGF aos 210 dias de gestação, o Flt-1 permaneceu inalterado. No entanto, aos 90 dias de gestação o Flt-1 apresentou uma expressão e um desvio padrão alto, o que dificultou posterior análise estatística.

No presente estudo, o KDR demonstrou uma expressão baixa no inicio da fase gestacional, o que não condiz com os dados de alguns pesquisadores como Neuvians et al. (2004), que descrevem a similaridade da expressão do VEGF com KDR nesta fase. Ao comparar a expressão do KDR entre 90 e 210 dias de gestação, observou-se um aumento $(p<0.05)$ no período de 210 dias de gestação. Esta baixa da expressão do KDR aos 90 dias, pode estar associada ao aumento da expressão do Flt-1 no mesmo período. Deve-se levar em consideração o desvio grande do Flt-1 no período de 90 dias de gestação. Por outro lado, a maior expressão do KDR aos 210 dias de gestação condiz com a regulação proposta por Neuvians et al. (2004) para o VEGF e o KDR.

Ė importante ressaltar que outro fator também está envolvido no processo angiogênico: o fator de crescimento fibroblastico (FGF) interage com o VEGF durante angiogênese, e estimula a proliferação de células endoteliais envolvidas na formação de novos vasos no corpo lúteo gestacional (NEUVIANS et al., 2004), e cíclico (REYNOLDS; REDMER., 2001; SCHAMS; BERISHA, 2004).

A partir do conhecimento da expressão fisiológica do sistema VEGF em função do avanço da gestação na placenta e corpo lúteo, pesquisas futuras poderão focar na modelação deste sistema para melhorar a fertilidade de animais clonados e não clonados. 


\section{CONCLUSÕES}


$7 \quad$ Conclusões

A partir de dados obtidos no recente estudo foi possível concluir que:

1 No placentoma bovino o fator de crescimento vascular endotelial (VEGF) e seus receptores (Flt-1 e KDR) são expressos de acordo com o padrão de proliferação vascular necessário para o desenvolvimento placentário e fetal.

2 O placentoma de bovinos clonados aos 270 dias de gestação demonstra diferenças individuais de expressão do sistema VEGF. Já o grupo controle apresenta expressão homogênea.

3 A regulação da expressão do sistema VEGF na região interplacentomal difere da regulação no placentoma.

4 A expressão do sistema VEGF no placentoma e região interplacentomal acontece de maneira inversamente proporcional.

5 A regulação da expressão do sistema VEGF no corpo lúteo difere da regulação no placentoma e região interplacentomal e parece estar diretamente relacionada à produção hormonal deste órgão. 
REFERÊNCIAS 


\section{REFERÊNCIAS}

ACHEN, M. G.; JELTSCH, M.; KUKK, E.; MAKINEN, T.; VITALI, A.; WILKS, A. F.; ALITALO, K.; STACKER, S. A. Vascular endothelial growth factor D (VEGF-D) is a ligand for the tyrosine kinases VEGF receptor 2 (Flk1) and VEGF receptor 3 (Flt4). Proc Natl Acad Sci U S A, v. 95, n. 2, p. 548-553, 1998.

ALLEN, W. R.; MATHIAS, S.; WOODING, F. B. P.; VAN AARDE, R. J. Placentation in the African elephant (Loxodonta africana): II morphological changes in the uterus and placenta throughout gestation. Placenta, v. 24, p. 598$617,2003$.

AHMED, A.; LI, X. F.; DUNK, C.; WHITTLE, M. J.; RUSHTON, D. I.; ROLLASON, T. Colocalizationof vascular endothelial growth factor and its Flt-1 receptor in human placenta. Growth Factors; v. 12, p. 235-243, 1995.

AVANZO, J. L. Carcinogênese pulmonar em camundongos portadores de deleção em um dos alelos do gene da Cx. 2005. 303 f. Tese (Doutorado em Ciências) - Faculdade de Medicina Veterinária e Zootecnia, Universidade de São Paulo, São Paulo, 2005.

AUGUSTIN, R.; POCAR, P.; NAVARRETE-SANTOS, A.; WRENZYCKI, C.; GANDOLFI, C.; NIEMANN, H.; FISCHER, B.Glucose transporter expression is developmentally regulated in in vitro derived bovine preimplantation embryos Molecular Reproduction and Development, v. 60, n.3, p. 370-376, 2001.

BABAWALE, M. O.; MOBBERLEY, M. A.; RYDER, T.A.; ELDER, M. G.; SULLIVAN, M.H.F. Ultrastructure of the early human feto-maternal interface cocultured in vitro. Hum Reprod, v. 17(5), p. 1351-7, 2002.

BARBONI, B.; TURRIANI, M.; GALEATI, G.; SPENACI, M.; BACCI, M. L.; FORNI, M.; MATTIOLI, M. Vascular endothelial growth factor production in growing pig antral follicles. Biol Reprod, v. 63, n.3, p. 858-864, 2000.

BARCROFT, J.; BARRON, D.H. Observations on the form and relations of the maternal and fetal vessels in the placenta of sheep. Anat Rec; v. 94, p. 569-595, 1946.

BERISHA. B.; SCHAMS. D. Ovarian function in ruminants. Domest Anim Endocrinol, v. 29, n.2, p. 305-317, 2005.

BERISHA, B.; PFAFFL, M. W.; SCHAMS, D. Expression of estrogen and progesterone receptors in the bovine ovary during estrous cycle and pregnancy. Endocrine, v. 17, p. 207-14, 2002. 
BERISHA, B.; SCHAMS, D.; KOSMANN, M.; AMSELGRUBER, W.; EINSPANIER, $R$. Expression and localisation of vascular endothelial growth factor and basic fibroblast growth factor during the final growth of bovine ovarian follicles. Journal of Endocrinology, v. 167, n. 3, p. 371-382, 2000.

BERNATCHEZ, P. N.; SOKER, S.; SIROIS, M. G. Vascular endothelial growth factor effect on endothelial cell proliferation, migration, and platelet-activating factor synthesis is Flk-1-dependent. Journal of Biological Chemistry, Baltimore, v. 274, n.43, p. 31047-31054, 1999.

BERTOLINI, M.; ANDERSON, G. B.; The placenta as a contributor to production of large calves. Theriogenology, v. 57, p. 181-187, 2002.

BHOJWANI, S.; VAJTA, G.; CALLESEN, H.; ROSCHLAU, K.; KUWER, A.; BECKER, F.; ALM, H.; TORNER, H.; KANITZ, W.; POEHLAND, R. Developmental competence of $\mathrm{HMC}(\mathrm{TM})$ derived bovine cloned embryos obtained from somatic cell nuclear transfer of adult fibroblasts and granulosa cells. JReprod, v. 51, n.4, p. 465-475, 2005.

BIRD, I. M.; SULLIVAN, J. A.; DI, T.; CALE, J. M.; ZHANG, L.; ZHENG, J.; MAGNESS, R. R.; Pregnancy dependent changes in cell signaling underlie changes in differential control of vasodilator production in uterine artery endothelial cells. Endocrinology, v. 141, p. 1107-1117, 2000.

BOGIC, L. V.; BRACE, R. A.; CHEUNG, C. Y. Developmental expression of vascular endothelial growth factor (VEGF) receptors and VEGF binding in ovine placenta and fetal membranes. Placenta, v. 22, n. 4, p. 265-275, 2001.

BOURC'HIS, D.; LE BOURHIS, D.; PATIN, D.; NIVELEAU, A.; COMEZZOLI, P.; RENARD, J. P.; VIEGAS-PEQUIGNOT, E. Delayed and incomplete reprogramming of chromosome methylation patterns in bovine cloned embryos. Curr Biol, v. 11, n.19, p. 1542-1546, 2001.

BREIER, G.; ALBRECHT, U.; STERRER, S.; RISAU, W. Expression of vascular endothelial growth factor during embryonic angiogenesis and endothelial cell differentiation. Development. v.114,n.2, p. 521-532, 1992.

BROWN. L. F.; DETMAR. M.; TOGNAZZI. K.; ABU-JAWDEH. G.; IRUELAARISPE. M. L. Uterine smooth muscle cells express functional receptors (flt-1 and KDR) for vascular permeability factor/vascular endothelial growth factor. Lab Invest, v. 76, n.2, p.245-255, 1997.

BUSSOLATI, B.; DUNK, C.; GROHMAN, M.; CHRISTOPHER, D.; MASON, K. J.; AHMED, A.Vascular endothelial growth factor receptor-1 modulates vascular endothelial growth factor-mediated angiogenesis via nitric oxide. Am J Pathol, v. 159, p. 993-1008, 2001. 
BUSSOLINO, F.; MANTOVANI, A.; PERSICO, G. Molecular nechanisms of blood vessel formation. Trends Biochem Sci, v. 22, n.7, p. 251-256, 1997.

CAMPOS, D. B. Imunolocalização do VEGF, bFGF e seus receptores na placenta bovina e influência destes fatores sobre a produção de progesterona pelas células placentárias em cultura. 2005. $193 \mathrm{f}$. Tese (Doutorado em Ciências) - Faculdade de Medicina Veterinária e Zootecnia, Universidade de São Paulo, São Paulo, 2005.

CARVALHO, I. Expressão e destribuição da conexina 43 nas células trofoblasticas gigantes bovinas em três fases gestacionais. 2004. $193 \mathrm{f}$. Dissertação (Mestrado em Ciências) - Faculdade de Medicina Veterinária e Zootecnia, Universidade de São Paulo, São Paulo, 2004.

CAO, R.; ERIKSSON, A.; KUBO, H.; ALITALO, K.; CAO, Y.; THYBERG, J. Comparative evaluation of FGF-2, VEGF-A, and VEGF-C induced angiogenesis, lymphangiogenesis, vascular fenestrations, and permeability. Circulation Research, v. p. 1-7, 2004.

CAVENDER. J L.; MEURDOCH. W. J. Morphological studies of the microcirculatory system of periovulatory ovine follicles. Biol Reprod, v. 39, n.4, p. 989-997, 1988.

CHARNOCK-JONES, D. S.; KAUFMANN, P.; MAYHEW, T. M.; Aspects of human fetoplacental vasculogenesis and angiogenesis. I. Molecular regulation. Placenta v. 25, p. 103-113, 2004.

CHARNOCK-JONES, D. S.; SHARKEY, A. M.; BOOCOCK, C. A.; AHMED, A.; PLEVIN, R.; FERRARA, N.; SMITH, S. K. Vascular endothelial growth factor receptor localization and activation in human trophoblast and choriocarcinoma cells. Biol Reprod, v. 51, n.3, p. 524-530, 1994.

CULLINAN-BOVE, K.; KOOS, R. D. Vascular endothelial growth factor/vascular permeability factor expression in the rat uterus: rapid stimulation by estrogen correlates with estrogen-induced increases in uterine capillary permeability and growth. Endocrinology. v. 133, n.2, p. 829-837, 1993.

CUNNIGHAM, S. A.; TRAN, T. M.; ARRATE, M. P.; BROCK, T. A. Characterization of vascular endothelial cell growth factor interactions with the kinase insert domain-containing receptor tyrosine kinase. A real time kinetic study. J Biol Chem, v. 274, n.26, p. 18421-18427, 1999.

CURWEN, V.; EYRAS, E.; ANDREWS, T. D.; CLARKE, L.; MONGIN, E.; SEARLE, S. M.; STABENAU, A.; STOREY, R.; CLAMP, M. The Ensembl automatic gene annotation system. Genome Res, v. 14, p. 942-950, 2004. http://w.w.w.ensembl.org/index.html 
DE VRIES, C.; ESCOBEDO, J. A.; VENO, H.; HOUCK, K.; FERRARA, N.; WILLIAMS, L. T. The fms-like tyrosine kinase, a receptor for vascular endothelial growth factor. Science, v. 255, n. 5047, p. 989-991, 1992.

DIAZ-FLORES, L.; GUTIERREZ, R.; VARELA, H. Angiogenesis: an update. Histol Histopathol. v. 9, n. 4, p. 807-843, 1994.

DULL, R. O.; YUAN, J.; CHANG, Y. S.; TARBELL, J.; JAIN, R. K.; MUNN, L. L. Kinetics of placenta growth factor/vascular endothelial growth factor synergy in endothelial hydraulic conductivity and proliferation. Microvascular Research, v. 61, p. 203-210, 2001.

FERRARA, N. Molecular and biological properties of vascular endothelial growth factor. J Mol Med, v. 77, n. 7, p. 527-543, 1999.

FERRARA, N.; DAVIS-SMYTH, T. The biology of vascular endothelial growth factor. Endocr Rev, v. 18, n. 1, p. 4-25, 1997.

FERRARA. N.; GERBER. H. P. The role of vascular endothelial growth factor in angiogenesis. Acta Haematol.; v. 106, n. 4, p. 148-156, 2001.

FOLKMAN. J. The influence of angiogenesis research on management of patients with breast cancer. Breast Cancer Res Treat, v. 36, n. 2, v. 109-118, 1995.

FOLKMAN, J.; SHING, Y. Angiogenesis. Journal of Biological Chemistry, Baltimore, v. 267, n. 16, p. 10931-10934, 1992.

FONG, G. H.; ROSSANT, J.; GERTSMSTEIN, M.; BREITMAN, M. L. Role of the Flt-1 receptor tyrosine kinase in regulating the assembly of vascular endothelium. Nature, v. 376, n. 6535, p. 66-70, 1995.

FORSYTHE, J. T.; JEANG, B. H.; IYER, N. V.; AGANI, F.; LEUNG, S. W.; KOOS, R. D.; SEMENZA, G. L. Activation of vascular endothelial growth factor gene transcription by hypoxia-inducible factor 1. Mol Cell Biol, v. 16, n. 9, p. 4604-4613, 1996.

FRASER, H. M.; LUNN, S. F. Regulation and manipulation of angiogenesis in the primate corpus luteum. Reproduction, v. 121, p. 355-6, 2001.

GUILLONOT, M. Cellular interactions during implantation in domestic ruminants. $\mathbf{J}$ Reprod Fertil; v. 49, p. 39-51, 1995. Supplement.

GRUNERT, E.; BIRGEL, E. H. Obstetrícia Veterinária. Porto Alegre: Ed. Sulina, p. 323, 1984.

HAFEZ, E. S. E. Reprodução Animal, ed. 6, editora Manole, p.59-114; 191-290, São Paulo, 1995. 
HATA, T.; KANENISHI, K.; INUBASHIRI, E.; TANAKA, H.; SENOH, D.; MANABE, A.; MIYAKE, K.; KONDOH, S. Three-dimensional sonographic features of placental abnormalities. Gynecol Obstet Invest, v. 57, p. 61-5, 2004.

HEYMAN, Y.; CHAVATTI-PALMER, P.; LEBOURHIS, D.; CAMOUS, S.; VIGNON, $X$;; RENARD, J. P. Frequency and occurrence of late-gestation losses from cattle cloned embryos. Biol Reprod, v. 66, n. 1, p. 6-13, 2002.

HILL, J. R.;ROUSSEL, A. J.; CIBELLI, J. B.; EDWARDS, J. F.; HOOPER, N .L.; MILLER, M. W.; ROBL, J. M.; STICE, S. L.; LONG, C. R.; LOONEY, C. R.; THOMPSON, J. A.; WESTHUSIN, M. E.Clinical and pathologic features of cloned transgenic calves and fetuses (13 case studies). Theriogenology, v. 51, n. 8, p. 1451-1465, 1999.

HILL, J. R.; WINTER, Q. A.; LONG, C. R.; LOONEY, C. R.; THOMPSON, J. A.; WESTHUSIN, M. E. Development rates of male bovine nuclear transfer embryos derived from adult and fetal cells. Biol Reprod, v. 62, n. 5, p. 1135-1140, 2000.

HOUCK, K. A.; FERRARA, N.; WINER, J.; CACHIANES, G.; LI, B.; LEUNG, D. W. The vascular endothelial growth factor family: identification of a fourth molecular species and characterization of alternative splicing of RNA. Mol Endocrinol, v. 5, n. 12 , p. 1806-1814, 1991.

HYDER, S. M.; CHIAPPETTA, C.; MURTHY, L.; STANCEL, G. M.; Selective inhibition of estrogen-regulated gene expression in vivo by the pure antiestrogen. Cancer Res, v. 57, p. 2547-2549, 1997.

ITOH, S.; BRAWLEY, L.; WHEELER, T.; ANTHONY, F. W.; POSTON, L.; HANSON, M. A. Vasodilation to vascular endothelial growth factor in the uterine artery of the pregnant rat is blunted by low dietary protein intake. Pediatr Res; v. 51, p. 485-491, 2002.

JACKSON, M. R.; CARNEY, E. W.; LYE, S. J.; RITCHIE, J. W. Localization of two angiogenic growth factors (PDECGF and VEGF) in human placentae throughout gestation. Placenta, v. 15, p. 341-353, 1994.

JOUKOV, V.; PAJUSOLA, K.; KAIPAINEN, A.; CHILOV, D.; LAHTINEN, I.; KUKK, E.; SAKSELA, O.; KALKKINEN, N.; ALITALO, K. A novel vascular endothelial growth factor, VEGF-C, is a ligand for the Flt4 (VEGFR-3) and KDR (VEGFR-2) receptor tyrosine kinases. EMBO J., v. 15, n. 9, p. 290-298, 1996.

LACERDA, P. M. O. Aspectos estereológicoss dos vilos da placenta de bovinos clonados. 2006. 77 f. Dissertação (Mestrado em Ciências) - Faculdade de Medicina Veterinária e Zootecnia, Universidade de São Paulo, São Paulo, 2006. 
LANG, I.; C. HOFFMANN, H.; OLIP, M. A.; PABST, T.; HAHN, G.; DOHR, G.; DESOYE, Differential mitogenic responses of human macrovascular and microvascular endothelial cells to cytokines underline their phenotypic heterogeneity. Cell Prolif., v. 34, p. 143-155, 2001

LEISER, R.; KREBS, C.; KLISCH, K.; EBERT, B.; DANTZER, V.;SCHULER, G.; KINGDOM, J. C.; KAUFMANN, P. Fetalvillosity and microvasculature of the bovine placentome in the secondhalf of gestation. Oxygen and placental vascular. $\mathbf{J}$ Anat;, v. 191, p. 517-527, 1997.

LI, W.; ALFAIDY, N.; CHALLIS, J. R. Expression of extracellular matrix metalloproteinase inducer in human placenta and fetal membranes at term. $\mathbf{J}$ Clin Endocrinol Metab, v. 89, p. 2897-2904, 2004.

KASHIDA, S.; SUGINO, N.; TAKEGUCHI, S.; KARUBE, A.; TAKAYAMA, H.; YAMAGOTO, Y. I.; NAKAMURA, Y.; KATO, H. Regulation and role of vascular endothelial growth factor in the corpus luteum during mid-pregnancy in rats. Biol Reprod, v. 64, p. 317-23, 2001.

KACZMAREK, M. M.; SCHAMS, D.; ZIECIK, A. J. Role of vascular endothelial growth factor in ovarian physiology - an overview. Reprod Biol, v. 5, n. 2, p. 111136, 2005.

KARURI, A. R.; KUMAR, A. M.; MUKHOPADHYAY, D. Differential expressionand selective localization of vascular permeability factor/vascular endothelial growth factor in the rat uterus during the estrous cycle. J Endocrinol, v. 159, p. 489-499, 1998.

KAUFMANN, P.; BLACK, S.; HUPPERTZ, B. Endovascular trophoblast invasion: implications for the pathogenesis of intrauterine growth retardation and preeclampsia. Biol Reprod, v. 69, n. 1, p. 1-7, 2003.

KAUFMANN, P.; BURTON, G. J.; KNOBIL, E.; NEILL, J. D.; GREENWALD, G. S.; MARKERT, C. L.; PFAFF, D. W. Anatomy and genesis of the placenta. editors. The physiology of reproduction. 2. ed., New York: Raven Press, 1994. p. $441-484$

KING, G. J.; ATKINSON, B. A.; ROBERTSON, H. A. Implantation and early placentation in domestic ungulates. J Reprod Fertil, v. 31, p. 17-30, 1982.

KONO. M.; TAKASHIMA. S.; LIU. H.; INOU. M.; KOJIIMA. N.; LU. Y. C.; HAMAMOTO. T.; TSUJI. S. Molecular cloning and functional expression of a fifthtype alpha 2,3 sialyltransferase (mST3Gal V: GM3 synthase). Biochem Biophys Res Commun, v. 253, n. 1, p. 170-175, 1998. 
MADAN, A.; CURTIN, P. T. A 24-base-pair sequence $3^{\prime}$ to the human erythropoietin gene contains a hypoxia-responsive transcriptional enhancer. Proc Natl Acad Sci U S A, v. 1;90, n.9, p. 3928-3932, 1993.

MAYHEW, T. M.; OHADIKE, C.; BAKER, P. N.; CROCKER, I. P.; MITCHELL, C.; ONG, S. S. Stereological investigation of placental morphology in pregnancies complicated by pre-eclampsia with and without intrauterine growth restriction.

Placenta.; v. 24, p. 219-26, 2003.

MOORE, K. L.; PERSAUD, T. V. N. Embriologia básica. Rio de Janeiro: Guanabara Koogan, 2000. p. 453.

MOURA, C. E. B. Expressão do VEGF e vascularização do corpo lúteo em búfalos. 2003. 122 f. Dissertação (Mestrado em Ciências) - Faculdade de Medicina Veterinária e Zootecnia, Universidade de São Paulo, São Paulo, 2003.

NAKAGAMA, Y.; FUJIMOTO, J.; TAMAYA, T. Placental growth by the estrogendependent angiogenic factors, vascular endothelial growth factor and basic fibroblast growth factor, throughout gestation. Gynecol Endocrinol. 2004

NAGY, J. A.; VASILE, E.; FENG, D.; SUNDBERG, C.; BROWN, L. F.; DETMAR, M. J.; LAWITTS, J. A.; BENJAMIN, L.; TAN, X.; MANSEAU, E. J.; DVORAK, A. M.; DVORAK, H. F. Vascular Permeability Factor/Vascular Endothelial Growth Factor Induces Lymphangiogenesis as well as Angiogenesis. J. Exp. Med, v. 196, n. 11, p. 1497-1506, 2002.

NIKLAUS, A. L.; BABESCHKIM, J. S.; ABERDEEN, G. W.; PEPE, G. J.; ALBRECHT, E. D. Expression of vascular endothelial growth/permeability factor by endometrial glandular epithelial and stromal cells in baboons during the menstrual cycle and after ovariectomy. Endocrinology, v. 143, p. 4007-17, 2002.

NIEMANN, H.; WRENZYCKI, C.; LUCAS-HAHN, A.; BRAMBRENK, T.; KUES, W. A.; CARNWATH, J. W. Gene expression patterns in bovine in vitro-produced and nuclear transfer-derived embryos and their implications for early development. Cloning Stem Cells, v. 4, n. 1, p. 29-38, 2002.

NEUVIANS, T. P.; BERISHA, B.; SCHAMS, D. Vascular Endothelial Growth Factor (VEGF)and Fibroblast Growth Factor (FGF) Expression During Induced Luteolysis in the Bovine Corpus Luteum. Molecular Reproduction and Development, V. 67, P. 389-395, (2004)

OHGANE, J.; HATTORI, N.; ODA, M.; TANAKA, S.; SHIOTA, K. Differentiation of trophoblast lineage is associated with DNA methylation and demethylation. Biochem. Biophys. Res. Commun. V. 290, p. 701-706, 2002. 
OLOFSSON, B.; PAJUSOLA, K.; KAIPAINEN, A.; VON EULER, G.; JOUKOV, V.; SAKSELA, O.; ORPANA, A.; PETTERSSON, R. F.; ALITALO, K.; ERIKSSON, U. Vascular endothelial growth factor $B$, a novel growth factor for endothelial cells (angiogenesisyendotheliumymitosis) . Proc. Natl. Acad. Sci. USA, v. 93, p. 25762581, 1996.

PAAVONEN, K.; HORELLI-KUITUNEN, N.; CHILOV, D.; KUKK, E.; PENNANEN, S.; KALLIONIEMI, O.; PAJUSOLA, K.; OLOFSSON, B.; ERIKSSON, U.; JOUKOV, V.; PALOTIE, A.; ALITALO, K. Novel Human Vascular Endothelial Growth Factor Genes VEGF-B and VEGF-C Localize to Chromosomes 11q13 and 4q34, Respectively Circulation, v. 93, p. 1079-1082, 1996

PAGE, E. W.; VILLEE, C. A.; VILLEE, D. B. Human reproduction. Philadelphia: W.B. Saunders, 1976. p. 394

PAWSON, T.; BEMSTEIN, A. Receptor tyrosine kinases: genetic evidence for their role in Drosophila and mouse development. Trends Genet, v. 6, n. 11, p. 350-356, 1990.

PERROT, A. M.; ANCELIN, M.; LOZANO, H. B.; MEDURI, G.;BAUSERO, P. Ovarian steroids in endometrial angiogenesis. Steroids, v. 65, p. 599-603, 2000.

PFARRER, C.; HIRSCH, P.; GUILLOMOT, M.; LEISER, R. Interaction of integrin receptors with extracellular matrix is involved in trophoblast giant cell migration in bovine placentomes. Placenta, v. 24, n. ?, p. 588-597, 2003.

PFAFFL, M. W. A ew mathematical model for relative quantification in real-time RT-PCR. Nucleic Acids Res, v. 29, p. 45, 2001.

PLENDL, J. Angiogenesis and vascular regression in the ovary. Anat Histol Embryol, v. 29, n.5, p. 257-266, 2000.

POLTORAK, Z.; COHEN, T.; SIVAN, R.; KANDELIS, Y.; SPIRA, G.; VLODAVSKY, I.; KESHET, E.; NEUFELD, G. VEGF145, a secreted vascular endothelial growth factor isoform that binds to extracellular matrix. Journal of Biological Chemistry, v. 272, n. 11, p. 7151-7158, 1997.

PUNYADEERA, C.; THIJSSEN, V. L.; TCHAIKOVSKI, S.; KAMPS, R.; DELVOUX, B.; DUNSELMAN, G. A.; GOEIJ, A. F.; GRIFFIOEN, A.W.; GROOTHUIS, P. G. Expression and regulation of vascular endothelial growth factor ligands and receptors during menstruation and post-menstrual repair of human endometrium. Mol Hum Reprod. 2006.

RAVELICH, S. R.; BREIER, B. H.; REDDY, S.; KEELAN, J. A.; WELLS, D. N.; PETERSON, A. J.; LEE, R. S. F. Insulin-like growth factor-I and binding proteins 1, 2 , and 3 in bovine nuclear transfer pregnancies. Biol Reprod, v. 70, p. 430-8, 2004. 
REDMER, D. A.; DAI, Y.; LI, J.; CHARNOCK-JONES, D. S.; SMITH, S. H.; REYNOLDS, L. P.; MOOR, R. M. Characterization and expression of vascular endothelial growth factor (VEGF) in the ovine corpus luteum. J Reprod Fertil, v. 108, n. 1, p. 157-165, 1996.

REYNOLDS, L. P.; KILLILEA, S. D.; REDMER, D. A. Angiogenesis in the female reproductive system. FASEB, v. 6, p. 886-892, 1992.

REYNOLDS, L. P.; KIRSCH, J. D.; KRAFT, K. C.; REDMER, D. A. Time course of theuterine response to estradiol-17b in ovariectomized ewes: expressionof angiogenic factors. Biol Reprod, v. 59, p. 613-620, 1998.

REYNOLDS, L. P.; REDMER, D. A. Angiogenesis in the placenta. Biol Reprod. v. 64, n. 4, p. 1033-1040, 2001.

REYNOLDS, L. P.; REDMER, D. A. Utero-placental vascular development and placental function. J. Anim Sci.;V. 73, n.6, p. 1839-1851, 1995.

RISAU, W. Mechanisms of angiogenesis. Nature, v. 386, p. 671-674, 1997

ROBINSON, C. J.; STRINGER, S. E. The splice variants of vascular endothelial growth factor (VEGF) and their receptors. J Cell Sci, v. 114, p. 853-865, 2001.

RODESCH, F.; SIMON, P.; DONNER, C.; JAUNIAUX, E. Oxygen measurements in endometrial and trophoblastic tissues during early pregnancy. Obstet Gynecol, v. 80, n. 2 , p. $283-285,1992$.

SCHAMS,. D.; BERISHA, B. Regulation of corpus luteum function in cattle-an overview. Reprod Domest Anim. v. 39, n. 4, p. 241-251, 2004.

SCHLAFER, D. H.; FISHER, P.J.; DAVIES, C. J. The bovine placenta before and after birth: placental development and function in health and disease. Animal Reproduction Science, v. 60-61, p. 145-160, 2000.

SHARKEY, A. M.; CHARNOCK-JONES, D. S.; BOOCOCK, C. A.; BROWN, K. D.; SMITH, S. K. Expression of mRNA for vascular endothelial growth factor in human placenta. J Reprod Fertil, v. 99, n. 2, p. 609-615, 1993.

SHIFREN, J. L.; DOLDI, N.; FERRARA, N.; MESIANO, S.; JAFFE, R. B. In the human fetus, vascular endothelial growth factor is expressed in epithelial cells and myocytes, but not vascular endothelium: implications for mode of action. J Clin Endocrinol Metab; v. 79, p. 316-322, 1994

SHORE, V. H.; WANG, T. H.; WANG, C. L.; TONY, R. J.; CAUDLE, M. R.; TONY, D. S. Vascular endothelial growth factor, placenta growth factor and their receptors in isolated human trophoblast. Placenta, v. 18, n. 8, p. 657-665, 1997. 
SON, W. Y.; YOON, S. H; LEE, S. W.; KO, Y.; YOON, H. G.; LIM, J. H. Blastocyst development and pregnancies after IVF of mature oocytes retrieved from unstimulated patients with PCOS after in-vivo HCG priming: Case report Human Reproduction, v. 17, n. 1, p. 134-136, 2002.

TERMAN, B. I.; DOUGHER-VERMAZEN, M.; CARRION, M. E.; DIMITROV, D.; ARMELLINO, D. C.; GOSPODAROWICZ, D.; BOHLEN, P. Identification of the KDR tyrosine kinase as a receptor for vascular endothelial cell growth factor. Biochem Biophys Res Commun, v. 187, n. 3, p. 1579-1586, 1992.

TISCHER, E.; MITCHELL, R.; HARTMAN, T.; SILVA, M.; GOSPODAROWICZ, D.; FIDDES, J. C.; ABRAHAM, J. A. The human gene for vascular endothelial growth factor. Multiple protein forms are encoded through alternative exon splicing. Journal of Biological Chemistry, v. 266, n. 18, p. 11947-11954, 1991.

TODROS, T.; SCIARRONI, A.; PICCOLI, E.; GUIOT, C.; KAUFMANN, P.; KINGDON, J. Umbilical Doppler waveforms and placental villous angiogenesis in pregnancies complicated by fetal growth restriction. Obstet Gynecol, v. 93, n. 4, p. 499-503, 1999.

TORRY, D. S.; WANG, H. S.; WANG, T. H.; CAUDLE, M. R.; TORRY, R. J. Preeclampsia is associated with reduced serum levels of placenta growth factor. Obstet Gynecol;v. 179, p. 1539-1544, 1998.

TRUDEINGER. B. J.; GILES. W. B.; COOK. C. M. Flow velocity waveforms in the maternal uteroplacental and fetal umbilical placental circulations. Am J Obstet Gynecol, v. 15, n. 2, p. 155-163, 1985.

TSENG, J.; HSU, S.; WEN, M.; HO, E.; CHOU, M. Expression of epidermal growth factor receptor and c-erbB-2 oncoprotein in trophoblast populations of placenta accreta. Am J Obstet Gynecol, v. 191, p. 2106-13, 2004.

VESALIUS, A. De humani corporis fabrica libri septum. Local: Basel, V1543, p. 659.

VONNAHME, K. A.; FORD, S. P. Biology of Reproduction. v. 71, p.163-169, 2004.

YAN, Z.; NEULEN, J.; RAZEK, S.; WEICH, H. A.; KECK, C.; GRUNWALD, K.; BRECKWOLDT, M. Vascular endothelial growth factor (VEGF)/vascular permeability factor (VPF) production by luteinized human granulosa cells in vitro; a paracrine signal in corpus luteum formation. Gynecol Endocrinol, v. 12, n. 3, p. 149-153, 1998.

YI, X. J.; JIANG, H. Y.; LEE, K. K.; O, W. S.; TANG, P. L.; CHOW, P. H. Expression of vascular endothelial growth factor (VEGF) and its receptors during 
embryonic im1plantation in the golden hamster (Mesocricetus auratus). Cell Tissue Res, v. 296, n. 2, p. 339-349, 1999.

YONEKUMURA, H.; SAKURAI,. S.; LIU, X.; MIGITA, H.; WANG, H.; YAMAGISHI, S.; NOMURA, M.; ABEDIN, M. J.; UNOKI, H.; YAMAMOTO, Y.; YAMAMOTO, H. Placenta growth factor and vascular endothelial growth factor $B$ and $C$ expression in microvascular endothelial cells and pericytes. Implication in autocrine and paracrine regulation of angiogenesis. J Biol Chem, v. 274, n. 49, p. 35172-35178, 1999.

YONEKURA, A.; OSAKI, M.; HIROTA, Y.; TSUKAZAKI, T.; MIYAZAKI, Y.; MATSUMOTO, T.; OHTSURU, A.; NAMBA, H.; SHINDO, H.; YAMASHITA, S. Transforming growth factor-beta stimulates articular chondrocyte cell growth through p44/42 MAP kinase (ERK) activation. Endocr J, v. 46, n. 4, p. 545-553, 1999.

YOSHIDA, A.; ANAND-APTE, ;B.; ZETTER, B. R. Differential endothelial migration and proliferation to basic fibroblast growth factor and vascular endothelial growth factor. Growth Factors., v. 13, n. 1-2, p. 57-64, 1996.

WANG, T.; HORNG, S.; CHANG, C.; WU, H.; TSAI, Y.; WANG, H.; SOONG, Y. Human chorionic gonadotropin-induced ovarian hyperstimulation syndrome is associated with up-regulation of vascular endothelial growth factor. The Journal of Clinical Endocrinology \& Metabolism, v. 87, n. 7, p. 3300-3308, 2002.

WEBB, R.; WOAD, K. Y.; AMSTRONG, D. G. Corpus luteum (CL) function: local control mechanisms. Domest Anim Endocrinol, v. 23, n. 1-2, p. 277-285, 2002.

WILLIAMS, B. Vascular permeability/vascular endothelial growth factors: a potential role in the pathogenesis and treatment of vascular diseases, Vasc Med, v. 1 , n. 4 , p. 251-258, 1996.

WILMUT, I.; SCHNIEKE, A. E.; MC WHIR, J.; KIND, A J.; CAMPBELL, K. H. Viable offspring derived from fetal and adult mammalian cells. Nature, v. 385, n. 6619, p. 810-813, 1997.

WILSON, M.E.; FORD, S. P. Comparative aspects of placental efficiency. Reprod Suppl, v. 58, p. 223-32, 2001.

WILSON, M. E.; BIENSEN, N. J.; FORD, S. P. Novel insight into the control of litter size in pigs, using placental efficiency as a selection tool. J AnimSci, v. 77, p. 1654-1658, 1999.

WINTHER, H.; AHMED, A.; DANTZER, V. Immunohistochemical localization of vascular endothelial growth factor (VEGF) and its two specific receptors, Flt-1 and KDR, in the porcine placenta and non-pregnant uterus. Placenta, v. 20, p. 35-43, 1999. 
WRENZYCKI, C.; NIEMANN, H. Epigenetic reprogramming in early embryonic development: effects of in-vitro production and somatic nuclear transfer. Reprod Biomed Online, v. 7, n. 6, p. 649-56, 2003.

ZHOU, Q.; BOULANGER, L.; RENARD, J. P. A simplified method for the reconstruction of fully competent mouse zygotes from adult somatic donor nuclei. Cloning, v. 2, n. 1, p. 35-44, 2000.

ZYGMUNT, M.; HERR, F.; MUNSTEDT, K.; UWE, L.; LIANG, O. D. Angiogenesis and vasculogenesis in pregnancy. European Journal of Obstrtrics \& Gynecology and Reproductive Biology, v. 110, p. S10-S18, 2003. 
Apêndice A

\begin{tabular}{|c|c|c|c|c|c|c|c|c|c|c|c|}
\hline \multirow{2}{*}{$\begin{array}{c}\text { Amostras de } \\
\text { placentoma }\end{array}$} & \multicolumn{3}{|c|}{ GAPDH } & \multicolumn{3}{|c|}{ VEGF } & \multirow{2}{*}{$\begin{array}{l}\text { DCP } \\
\text { alvo }\end{array}$} & \multirow[b]{2}{*}{ DCP ref } & \multirow[b]{2}{*}{ EDCPalvo } & \multirow[b]{2}{*}{ EDCPref } & \multirow[b]{2}{*}{ exp rel } \\
\hline & $\mathrm{Ct}$ & $\mathrm{Ct}$ & media & $\mathrm{Ct}$ & $\mathrm{Ct}$ & media & & & & & \\
\hline $45 \mathrm{D} P L$ & 27,5 & 27,75 & 27,63 & 31,64 & 31,57 & 31,61 & $-26,26$ & $-22,28$ & 5,96 & 6,64 & 0,90 \\
\hline $60 \mathrm{D} P L$ & 23,69 & 22,96 & 23,33 & 27,73 & 27,83 & 27,78 & $-22,43$ & $-17,98$ & 4,59 & 4,61 & 1,00 \\
\hline $90 \mathrm{D} \mathrm{PL}$ & 23,72 & 23,77 & 23,75 & 29,33 & 29,24 & 29,29 & $-23,94$ & $-18,40$ & 5,09 & 4,77 & 1,07 \\
\hline $90 \mathrm{D}$ PL & 22,66 & 22,64 & 22,65 & 27,89 & 27,82 & 27,86 & $-22,51$ & $-17,30$ & 4,62 & 4,35 & 1,06 \\
\hline $90 \mathrm{D} P L$ & 23,51 & 23,73 & 23,62 & 29,07 & 29,1 & 29,09 & $-23,74$ & $-18,27$ & 5,02 & 4,72 & 1,06 \\
\hline $90 \mathrm{D} \mathrm{PL}$ & 23,38 & 23,33 & 23,36 & 28,52 & 28,56 & 28,54 & $-23,19$ & $-18,01$ & 4,84 & 4,62 & 1,05 \\
\hline $150 \mathrm{D} \mathrm{PL}$ & 23,73 & 23,63 & 23,68 & 26,62 & 26,83 & 26,73 & $-21,38$ & $-18,33$ & 4,28 & 4,75 & 0,90 \\
\hline $150 \mathrm{DPL}$ & 22,78 & 22,91 & 22,85 & 27,93 & 28 & 27,97 & $-22,62$ & $-17,50$ & 4,65 & 4,42 & 1,05 \\
\hline $150 \mathrm{DPL}$ & 24,18 & 24,21 & 24,20 & 29,61 & 29,52 & 29,57 & $-24,22$ & $-18,85$ & 5,19 & 4,96 & 1,05 \\
\hline $150 \mathrm{DPL}$ & 25,17 & 25,22 & 25,20 & 30,34 & 30,27 & 30,31 & $-24,96$ & $-19,85$ & 5,45 & 5,40 & 1,01 \\
\hline $210 \mathrm{D} P \mathrm{PL}$ & 23,58 & 23,57 & 23,58 & 27,85 & 27,94 & 27,90 & $-22,55$ & $-18,23$ & 4,63 & 4,71 & 0,98 \\
\hline $210 \mathrm{D} P \mathrm{PL}$ & 23,73 & 23,86 & 23,80 & 28,36 & 28,39 & 28,38 & $-23,03$ & $-18,45$ & 4,78 & 4,79 & 1,00 \\
\hline $210 \mathrm{D} P L$ & 24,42 & 24,59 & 24,51 & 29,15 & 29,16 & 29,16 & $-23,81$ & $-19,16$ & 5,04 & 5,09 & 0,99 \\
\hline $210 \mathrm{D} P L$ & 22,92 & 22,95 & 22,94 & 27,56 & 27,44 & 27,50 & $-22,15$ & $-17,59$ & 4,51 & 4,46 & 1,01 \\
\hline $270 \mathrm{D} P L$ & 23,57 & 23,77 & 23,67 & 28,24 & 28,16 & 28,20 & $-22,85$ & $-18,32$ & 4,73 & 4,74 & 1,00 \\
\hline $270 \mathrm{D} P L$ & 24,25 & 24,21 & 24,23 & 28,01 & 28,01 & 28,01 & $-22,66$ & $-18,88$ & 4,67 & 4,97 & 0,94 \\
\hline $270 \mathrm{D} P L$ & 24,34 & 24,35 & 24,35 & 27,31 & 27,29 & 27,30 & $-21,95$ & $-19,00$ & 4,45 & 5,02 & 0,89 \\
\hline $270 \mathrm{D} P L$ & 26,01 & 25,83 & 25,92 & 29,46 & 29,43 & 29,45 & $-24,10$ & $-20,57$ & 5,14 & 5,74 & 0,90 \\
\hline
\end{tabular}

Quadro 5 - Representa a corrida de PCR em tempo real com os valores de cada Ct para o GADPH e VEGF, e a média das duplicatas realizadas para cada amostra. DCP alvo representa o calibrador menos o gene alvo, DCP ref. representa o calibrador menos o controle endógeno, EDCP alvo representa a eficiência elevada a $\triangle D C P$ alvo, EDPC ref. representa a eficiência elevada a $\triangle D C P$ ref, Exp. Rel. representa EDPC alvo dividido pelo EDPC ref 


\section{Apêndice B}

\begin{tabular}{|c|c|c|c|c|c|c|c|c|c|c|}
\hline \multirow{2}{*}{$\begin{array}{l}\text { Amostras de } \\
\text { placentoma }\end{array}$} & \multicolumn{3}{|c|}{ Flt-1 } & \multirow[b]{2}{*}{$\mathrm{Ct}$} & \multirow[b]{2}{*}{$\mathrm{Ct}$} & \multirow[b]{2}{*}{ media } & \multirow[b]{2}{*}{$\mathrm{DCt}$} & \multirow[b]{2}{*}{ calibrador } & \multirow[b]{2}{*}{ DDCt } & \multirow[b]{2}{*}{ exp rel } \\
\hline & $\mathrm{Ct}$ & $\mathrm{Ct}$ & media & & & & & & & \\
\hline $45 \mathrm{DPL}$ & 27,63 & undet & undet & \#DIV/0 & & \#DIV/0! & & \#DIV/O! & & \#\#\#\#\# \\
\hline $60 \mathrm{DPL}$ & 23,33 & 36,95 & 36,58 & 36,77 & 5,35 & $-31,42$ & $-17,98$ & 0,10 & 3,74 & 0,03 \\
\hline $90 \mathrm{DPL}$ & 23,75 & 34,21 & 34,32 & 34,27 & 5,35 & $-28,92$ & $-18,40$ & 0,12 & 3,86 & 0,03 \\
\hline $90 \mathrm{DPL}$ & 22,65 & 32,18 & 32,05 & 32,12 & 5,35 & $-26,77$ & $-17,30$ & 0,14 & 3,56 & 0,04 \\
\hline $90 \mathrm{DPL}$ & 23,62 & 32,84 & 32,41 & 32,63 & 5,35 & $-27,28$ & $-18,27$ & 0,13 & 4,72 & 0,03 \\
\hline $90 \mathrm{DPL}$ & 23,36 & 32,28 & 32,29 & 32,13 & 5,35 & $-26,78$ & $-18,01$ & 0,14 & 4,62 & 0,03 \\
\hline $150 \mathrm{DPL}$ & 23,68 & 32,07 & 32,19 & 32,13 & 5,35 & $-26,78$ & $-18,33$ & 0,14 & 4,75 & 0,03 \\
\hline $150 \mathrm{DPL}$ & 22,85 & 32,28 & 32,51 & 32,40 & 5,35 & $-27,05$ & $-17,50$ & 0,14 & 4,42 & 0,03 \\
\hline $150 \mathrm{DPL}$ & 24,20 & 34,26 & 34,33 & 34,30 & 5,35 & $-28,95$ & $-18,85$ & 0,12 & 4,96 & 0,02 \\
\hline $150 \mathrm{DPL}$ & 25,20 & 33,5 & 33,5 & 33,50 & 5,35 & $-28,15$ & $-19,85$ & 0,13 & 5,40 & 0,02 \\
\hline $210 \mathrm{D} P L$ & 23,58 & 31,75 & 31,78 & 31,77 & 5,35 & $-26,42$ & $-18,23$ & 0,14 & 4,71 & 0,03 \\
\hline $210 \mathrm{DPL}$ & 23,80 & 33,4 & 33,46 & 33,43 & 5,35 & $-28,08$ & $-18,45$ & 0,13 & 4,79 & 0,03 \\
\hline $210 \mathrm{DPL}$ & 24,51 & 35,13 & 35,3 & 35,22 & 5,35 & $-29,87$ & $-19,16$ & 0,11 & 5,09 & 0,02 \\
\hline $210 \mathrm{D} P \mathrm{PL}$ & 22,94 & 31,83 & 32,01 & 31,92 & 5,35 & $-26,57$ & $-17,59$ & 0,14 & 4,46 & 0,03 \\
\hline $270 \mathrm{D} P L$ & 23,67 & 33,27 & 32,8 & 33,04 & 5,35 & $-27,69$ & $-18,32$ & 0,13 & 4,74 & 0,03 \\
\hline $270 \mathrm{D} P \mathrm{PL}$ & 24,23 & 33,2 & 33,2 & 33,20 & 5,35 & $-27,85$ & $-18,88$ & 0,13 & 4,97 & 0,03 \\
\hline $270 \mathrm{D} P L$ & 24,35 & 32,62 & 32,39 & 32,51 & 5,35 & $-27,16$ & $-19,00$ & 0,14 & 5,02 & 0,03 \\
\hline $270 \mathrm{D} P L$ & 25,92 & 33,1 & 33,27 & 33,19 & 5,35 & $-27,84$ & $-20,57$ & 0,13 & 5,74 & 0,02 \\
\hline
\end{tabular}

Quadro 6 - Representa a corrida de PCR em tempo real com os valores de cada (Ct) para o Flt-1, e a média das duplicatas realizadas para cada amostra. DCP alvo. representa o calibrador menos o gene alvo, DCP ref. representa o calibrador menos o controle endógeno, EDCP alvo representa a eficiência elevada a $\triangle D C P$ alvo, EDPC ref. representa a eficiência elevada a $\triangle \mathrm{DCP}$ ref, Exp. Rel. representa EDPC alvo dividido pelo EDPC ref 


\section{Apêndice C}

\begin{tabular}{|c|c|c|c|c|c|c|c|c|c|c|}
\hline \multirow[b]{2}{*}{$\begin{array}{l}\text { Amostras } \\
\text { Placentoma }\end{array}$} & \multicolumn{3}{|c|}{ KDR } & \multirow[b]{2}{*}{ calibrador } & \multirow[b]{2}{*}{$\begin{array}{l}\text { DCP } \\
\text { alvo }\end{array}$} & \multirow[b]{2}{*}{ DCP ref } & \multirow[b]{2}{*}{ EDCPalvo } & \multirow[b]{2}{*}{ EDCPref } & \multirow[b]{2}{*}{ exp rel } & \multirow[b]{2}{*}{$\mathrm{Ct}$} \\
\hline & $\mathrm{Ct}$ & $\mathrm{Ct}$ & media & & & & & & & \\
\hline $45 \mathrm{D} P L$ & 27,625 & undet & undet & & & & & & & \\
\hline $60 \mathrm{DPL}$ & 23,325 & 23,69 & 22,96 & 23,33 & 5,35 & $-17,98$ & $-17,98$ & 0,43 & 2,31 & 0,19 \\
\hline $90 \mathrm{DPL}$ & 23,75 & 29,85 & 29,85 & 29,85 & 5,35 & $-24,50$ & $-18,40$ & 0,32 & 4,77 & 0,07 \\
\hline $90 \mathrm{DPL}$ & 22,65 & 31,62 & 31,53 & 31,58 & 5,35 & $-26,23$ & $-17,3$ & 0,29 & 4,35 & 0,07 \\
\hline $90 \mathrm{DPL}$ & 23,62 & 31,17 & 31,14 & 31,16 & 5,35 & $-25,81$ & $-18,27$ & 0,30 & 4,72 & 0,06 \\
\hline $90 \mathrm{DPL}$ & 23,36 & 30,22 & 30,27 & 31,05 & 5,35 & $-25,70$ & $-18,005$ & 0,30 & 4,62 & 0,07 \\
\hline $150 \mathrm{DPL}$ & 23,68 & 31,08 & 31,01 & 31,05 & 5,35 & $-25,70$ & $-18,33$ & 0,30 & 4,75 & 0,06 \\
\hline $150 \mathrm{DPL}$ & 22,85 & 31,07 & 31,2 & 31,14 & 5,35 & $-25,79$ & $-17,495$ & 0,30 & 4,42 & 0,07 \\
\hline $150 \mathrm{DPL}$ & 24,20 & 33,43 & 33,48 & 33,46 & 5,35 & $-28,11$ & $-18,845$ & 0,27 & 4,96 & 0,05 \\
\hline $150 \mathrm{D} P \mathrm{PL}$ & 25,20 & 32,23 & 32,17 & 32,20 & 5,35 & $-26,85$ & $-19,845$ & 0,29 & 5,40 & 0,05 \\
\hline $210 \mathrm{DPL}$ & 23,58 & 30,49 & 30,21 & 30,35 & 5,35 & $-25,00$ & $-18,225$ & 0,31 & 4,71 & 0,07 \\
\hline $210 \mathrm{D} P \mathrm{PL}$ & 23,80 & 30,89 & 30,91 & 30,90 & 5,35 & $-25,55$ & $-18,445$ & 0,30 & 4,79 & 0,06 \\
\hline $210 \mathrm{D} P \mathrm{PL}$ & 24,51 & 32,78 & 33,04 & 32,91 & 5,35 & $-27,56$ & $-19,155$ & 0,28 & 5,09 & 0,05 \\
\hline $210 \mathrm{DPL}$ & 22,94 & 30,8 & 30,87 & 30,84 & 5,35 & $-25,49$ & $-17,585$ & 0,30 & 4,46 & 0,07 \\
\hline $270 \mathrm{D} P L$ & 23,67 & 31,43 & 31,64 & 31,54 & 5,35 & $-26,19$ & $-18,32$ & 0,29 & 4,74 & 0,06 \\
\hline $270 \mathrm{D} P L$ & 24,23 & 32,1 & 32,12 & 32,11 & 5,35 & $-26,76$ & $-18,88$ & 0,29 & 4,97 & 0,06 \\
\hline $270 \mathrm{D} P \mathrm{PL}$ & 24,35 & 30,54 & 30,54 & 30,54 & 5,35 & $-25,19$ & $-18,995$ & 0,31 & 5,02 & 0,06 \\
\hline $270 \mathrm{D} P L$ & 25.92 & 33.84 & 34.21 & 34.03 & 5.35 & -28.68 & -20.57 & 0.26 & 5.74 & 0.05 \\
\hline
\end{tabular}

Quadro 7 - Representa a corrida de PCR em tempo real com os valores de cada (Ct) para o KDR, e a média das duplicatas realizadas para cada amostra. DCP alvo representa o calibrador menos o gene alvo, DCP ref. representa 0 calibrador menos o controle endógeno, EDCP alvo representa a eficiência elevada a $\triangle \mathrm{DCP}$ alvo, EDPC ref. representa a eficiência elevada a $\triangle \mathrm{DCP}$ ref, Exp. Rel. representa EDPC alvo dividido pelo EDPC ref 


\section{Apêndice D}

\begin{tabular}{|c|c|c|c|c|c|c|c|c|c|c|c|}
\hline \multirow{2}{*}{$\begin{array}{l}\text { Amostras de } \\
\text { placentoma } \\
\text { de clones e } \\
\text { não clones }\end{array}$} & \multicolumn{3}{|c|}{ GAPDH } & \multicolumn{3}{|c|}{ VEGF } & \multirow[b]{2}{*}{$\begin{array}{l}\text { DCP } \\
\text { alvo }\end{array}$} & \multirow[b]{2}{*}{ DCP ref } & \multirow[b]{2}{*}{ EDCPalvo } & \multirow[b]{2}{*}{ EDCPref } & \multirow[b]{2}{*}{ exp rel } \\
\hline & $\mathrm{Ct}$ & $\mathrm{Ct}$ & media & $\mathrm{Ct}$ & $\mathrm{Ct}$ & media & & & & & \\
\hline $270 \mathrm{D} P L$ & 23,57 & 23,77 & 23,67 & 28,24 & 28,16 & 28,20 & $-24,50$ & $-19,97$ & 5,29 & 5,46 & 0,97 \\
\hline $270 \mathrm{D} P L$ & 24,25 & 24,21 & 24,23 & 28,01 & 28,01 & 28,01 & $-24,31$ & $-20,53$ & 5,22 & 5,72 & 0,91 \\
\hline $270 \mathrm{D} P L$ & 24,34 & 24,35 & 24,35 & 27,31 & 27,29 & 27,30 & $-23,60$ & $-20,65$ & 4,97 & 5,78 & 0,86 \\
\hline $270 \mathrm{D} P L$ & 26,01 & 25,83 & 25,92 & 29,46 & 29,43 & 29,45 & $-25,75$ & $-22,22$ & 5,76 & 6,61 & 0,87 \\
\hline penta & 22,47 & 22,41 & 22,44 & 25,01 & 24,89 & 24,95 & $-21,25$ & $-18,74$ & 4,24 & 4,92 & 0,86 \\
\hline bela & 22,53 & 22,61 & 22,57 & 26,34 & 26,39 & 26,37 & $-22,67$ & $-18,87$ & 4,67 & 4,97 & 0,94 \\
\hline independencia & 24,58 & 24,47 & 24,53 & 28,78 & 28,66 & 28,72 & $-25,02$ & $-20,83$ & 5,48 & 5,87 & 0,93 \\
\hline mortolina & 22,47 & 22,58 & 22,53 & 24,67 & 24,61 & 24,64 & $-20,94$ & $-18,83$ & 4,15 & 4,95 & 0,84 \\
\hline 3.3 & 25,78 & 25,64 & 25,71 & 29,84 & 29,86 & 29,85 & $-26,15$ & $-22,01$ & 5,92 & 6,49 & 0,91 \\
\hline 3.4 & 23,78 & 23,84 & 23,81 & 26,47 & 26,52 & 26,50 & $-22,80$ & $-20,11$ & 4,71 & 5,52 & 0,85 \\
\hline 3.5 & 24,43 & 24,47 & 24,45 & 36,81 & 36,2 & 36,51 & $-32,81$ & $-20,75$ & 9,30 & 5,83 & 1,59 \\
\hline 3.6 & 25,68 & 25,59 & 25,64 & 30,66 & 30,64 & 30,65 & $-26,95$ & $-21,94$ & 6,25 & 6,45 & 0,97 \\
\hline
\end{tabular}

Quadro 8 - Representa a corrida de PCR em tempo real com os valores de cada (Ct) para o GADPH e VEGF, e a média das duplicatas realizadas para cada amostra. DCP alvo representa o calibrador menos o gene alvo, DCP ref. representa o calibrador menos o controle endógeno, EDCP alvo representa a eficiência elevada a $\triangle \mathrm{DCP}$ alvo, EDPC ref. representa a eficiência elevada a $\triangle \mathrm{DCP}$ ref, Exp. Rel. representa EDPC alvo dividido pelo EDPC ref 
Apêndice $E$

\begin{tabular}{|c|c|c|c|c|c|c|c|c|c|}
\hline \multirow{2}{*}{$\begin{array}{l}\text { Amostras de } \\
\text { placentoma } \\
\text { de clones e } \\
\text { não clones }\end{array}$} & \multicolumn{3}{|c|}{ Flt-1 } & \multirow[b]{2}{*}{ calibrador } & \multirow[b]{2}{*}{$\begin{array}{l}\text { DCP } \\
\text { alvo }\end{array}$} & \multirow[b]{2}{*}{$\begin{array}{l}\mathrm{DCP} \\
\text { ref }\end{array}$} & \multirow[b]{2}{*}{ EDCPalvo } & \multirow[b]{2}{*}{ EDCPref } & \multirow[b]{2}{*}{ exp rel } \\
\hline & $\mathrm{Ct}$ & $\mathrm{Ct}$ & media & & & & & & \\
\hline $270 \mathrm{D} P L$ & 33,27 & 32,8 & 33,04 & 3,70 & $-29,34$ & $-19,97$ & 0,12 & 5,46 & 0,02 \\
\hline $270 \mathrm{D} P L$ & 33,2 & 33,2 & 33,20 & 3,70 & $-29,50$ & $-20,53$ & 0,11 & 5,72 & 0,02 \\
\hline $270 \mathrm{D} P L$ & 32,62 & 32,39 & 32,51 & 3,70 & $-28,81$ & $-20,65$ & 0,12 & 5,78 & 0,02 \\
\hline $270 \mathrm{D} P L$ & 33,1 & 33,27 & 33,19 & 3,70 & $-29,49$ & $-22,22$ & 0,11 & 6,61 & 0,02 \\
\hline penta & 30,4 & 30,48 & 30,44 & 3,70 & $-26,74$ & $-18,74$ & 0,14 & 4,92 & 0,03 \\
\hline bela & 30,45 & 30,54 & 30,50 & 3,70 & $-26,80$ & $-18,87$ & 0,14 & 4,97 & 0,03 \\
\hline independencia & 33,23 & 33,47 & 33,35 & 3,70 & $-29,65$ & $-20,83$ & 0,11 & 5,87 & 0,02 \\
\hline mortolina & 30,15 & 30,22 & 30,19 & 3,70 & $-26,49$ & $-18,83$ & 0,14 & 4,95 & 0,03 \\
\hline 3.3 & 34,54 & 34,35 & 34,45 & 3,70 & $-30,75$ & $-22,01$ & 0,10 & 6,49 & 0,02 \\
\hline 3.4 & 31,30 & 31,46 & 31,38 & 3,70 & $-27,68$ & $-20,11$ & 0,13 & 5,52 & 0,02 \\
\hline 3.5 & 31,25 & 31,24 & 31,25 & 3,70 & $-27,55$ & $-20,75$ & 0,13 & 5,83 & 0,02 \\
\hline 3.6 & 34,62 & 35,02 & 34,82 & 3,70 & $-31,12$ & $-21,94$ & 0,10 & 6,45 & 0,02 \\
\hline
\end{tabular}

Quadro 9 - Representa a corrida de PCR em tempo real com os valores de cada (Ct) para o Flt-1, e a média das duplicatas realizadas para cada amostra. . DCP alvo representa o calibrador menos o gene alvo, DCP ref. representa o calibrador menos o controle endógeno, EDCP alvo representa a eficiência elevada a $\triangle \mathrm{DCP}$ alvo, EDPC ref. representa a eficiência elevada a $\triangle \mathrm{DCP}$ ref, Exp. Rel. representa EDPC alvo dividido pelo EDPC ref 
Apêndice $F$

\begin{tabular}{|c|c|c|c|c|c|c|c|c|c|}
\hline \multirow{2}{*}{$\begin{array}{l}\text { Amostras de } \\
\text { placentoma } \\
\text { de clones e } \\
\text { não clones }\end{array}$} & \multicolumn{3}{|c|}{ KDR } & \multirow[b]{2}{*}{ calibrador } & \multirow[b]{2}{*}{\begin{tabular}{|l|} 
DCP \\
alvo \\
\end{tabular}} & \multirow[b]{2}{*}{$\begin{array}{l}\text { DCP } \\
\text { ref } \\
\end{array}$} & \multirow[b]{2}{*}{ EDCPalvo } & \multirow[b]{2}{*}{ EDCPref } & \multirow[b]{2}{*}{ exp rel } \\
\hline & $\mathrm{Ct}$ & $\mathrm{Ct}$ & media & & & & & & \\
\hline $270 \mathrm{D} P L$ & 31,43 & 31,64 & 31,54 & 3,70 & $-27,84$ & $-19,97$ & 0,27 & 5,46 & 0,05 \\
\hline $270 \mathrm{D} P L$ & 32,1 & 32,12 & 32,11 & 3,70 & $-28,41$ & $-20,53$ & 0,27 & 5,72 & 0,05 \\
\hline $270 \mathrm{D} P L$ & 30,54 & 30,54 & 30,54 & 3,70 & $-26,84$ & $-20,65$ & 0,29 & 5,78 & 0,05 \\
\hline $270 \mathrm{D} P L$ & 33,84 & 34,21 & 34,03 & 3,70 & $-30,33$ & $-22,22$ & 0,24 & 6,61 & 0,04 \\
\hline penta & 28,45 & 28,58 & 28,52 & 3,70 & $-24,82$ & $-18,74$ & 0,31 & 4,92 & 0,06 \\
\hline bela & 29,78 & 29,88 & 29,83 & 3,70 & $-26,13$ & $-18,87$ & 0,30 & 4,97 & 0,06 \\
\hline independencia & 31,88 & 32,03 & 31,96 & 3,70 & $-28,26$ & $-20,83$ & 0,27 & 5,87 & 0,05 \\
\hline mortolina & 28,04 & 28,1 & 28,07 & 3,70 & $-24,37$ & $-18,83$ & 0,32 & 4,95 & 0,06 \\
\hline 3.3 & 34,05 & 33,77 & 33,91 & 3,70 & $-30,21$ & $-22,01$ & 0,24 & 6,49 & 0,04 \\
\hline 3.4 & 30,46 & 30,55 & 30,51 & 3,70 & $-26,81$ & $-20,11$ & 0,29 & 5,52 & 0,05 \\
\hline 3.5 & 35,61 & 36,15 & 35,88 & 3,70 & $-32,18$ & $-20,75$ & 0,22 & 5,83 & 0,04 \\
\hline 3.6 & 34,52 & 34,73 & 34,63 & 3,70 & $-30,93$ & $-21,94$ & 0,24 & 6,45 & 0,04 \\
\hline
\end{tabular}

Quadro 10 - Representa a corrida de PCR em tempo real com os valores de cada (Ct) para o KDR, e a média das duplicatas realizadas para cada amostra. DCP alvo representa o calibrador menos o gene alvo, DCP ref. representa o calibrador menos o controle endógeno, EDCP alvo representa a eficiência elevada a $\triangle \mathrm{DCP}$ alvo, EDPC ref. representa a eficiência elevada a $\triangle \mathrm{DCP}$ ref, Exp. Rel. representa EDPC alvo dividido pelo EDPC ref 
Apêndice G

\begin{tabular}{|c|c|c|c|c|c|c|c|c|c|c|c|}
\hline \multirow{2}{*}{$\begin{array}{l}\text { Amostras da } \\
\text { região } \\
\text { interplacentomal }\end{array}$} & \multicolumn{3}{|c|}{ GAPDH } & \multicolumn{3}{|c|}{ VEGF } & \multirow[b]{2}{*}{$\begin{array}{l}\text { DCP } \\
\text { alvo }\end{array}$} & \multirow[b]{2}{*}{ DCP ref } & \multirow[b]{2}{*}{$\begin{array}{c}\text { EDCPalv } \\
\text { o }\end{array}$} & \multirow[b]{2}{*}{$\begin{array}{c}\text { EDCPre } \\
f\end{array}$} & \multirow[b]{2}{*}{ exp rel } \\
\hline & $\mathrm{Ct}$ & $\mathrm{Ct}$ & media & $\mathrm{Ct}$ & $\mathrm{Ct}$ & media & & & & & \\
\hline 45 D região & 22,76 & 22,85 & 22,81 & 29,52 & 29,71 & 29,62 & $-21,77$ & $-14,96$ & 4,39 & 3,57 & 1,23 \\
\hline 60 D região & 23,67 & 23,99 & 23,83 & 30,17 & 30,26 & 30,22 & $-22,38$ & $-15,99$ & 4,58 & 3,89 & 1,18 \\
\hline $90 \mathrm{D}$ região & 24,11 & 24,28 & 24,20 & 30,94 & 30,97 & 30,96 & $-23,12$ & $-16,36$ & 4,81 & 4,01 & 1,20 \\
\hline $90 \mathrm{D}$ região & 23,79 & 23,82 & 23,81 & 30,65 & 30,67 & 30,66 & $-22,82$ & $-15,97$ & 4,72 & 3,88 & 1,21 \\
\hline 90 D região & 25,85 & 25,63 & 25,74 & 35,26 & 35,44 & 35,35 & $-27,51$ & $-17,90$ & 6,49 & 4,58 & 1,42 \\
\hline 90 D região & 25,2 & 25,24 & 25,22 & 33,46 & 33,28 & 33,37 & $-25,53$ & $-17,38$ & 5,67 & 4,38 & 1,30 \\
\hline 150 D região & 23,92 & 23,98 & 23,95 & 33,5 & 33,25 & 33,38 & $-25,54$ & $-16,11$ & 5,67 & 3,93 & 1,44 \\
\hline 150 D região & 22,36 & 22,42 & 22,39 & 28,34 & 28,48 & 28,41 & $-20,57$ & $-14,55$ & 4,05 & 3,44 & 1,18 \\
\hline 150 D região & 21,04 & 21,16 & 21,10 & 28,01 & 28,07 & 28,04 & $-20,20$ & $-13,26$ & 3,95 & 3,09 & 1,28 \\
\hline 150 D região & 22 & 22 & 22,00 & 29,6 & 29,74 & 29,67 & $-21,83$ & $-14,16$ & 4,41 & 3,33 & 1,32 \\
\hline 210 D região & 24,3 & 24,35 & 24,33 & 32,15 & 32,04 & 32,10 & $-24,26$ & $-16,49$ & 5,20 & 4,06 & 1,28 \\
\hline 210 D região & 21,98 & 21,98 & 21,98 & 30,05 & 30,07 & 30,06 & $-22,22$ & $-14,14$ & 4,53 & 3,33 & 1,36 \\
\hline 210 D região & 25,17 & 25,03 & 25,10 & 32,69 & 32,6 & 32,65 & $-24,81$ & $-17,26$ & 5,40 & 4,34 & 1,25 \\
\hline 210 D região & 21,39 & 21,37 & 21,38 & 28,42 & 28,45 & 28,44 & $-20,60$ & $-13,54$ & 4,06 & 3,16 & 1,28 \\
\hline 270 D região & 24,66 & 24,57 & 24,62 & 35,95 & 35,85 & 35,90 & $-28,06$ & $-16,78$ & 6,74 & 4,16 & 1,62 \\
\hline
\end{tabular}

Quadro 11 - Representa a corrida de PCR em tempo real com os valores de cada (Ct) para o GADPH e VEGF, e a média das duplicatas realizadas para cada amostra. DCP alvo representa o calibrador menos o gene alvo, DCP ref. representa o calibrador menos o controle endógeno, EDCP alvo representa a eficiência elevada a $\triangle \mathrm{DCP}$ alvo, EDPC ref. representa a eficiência elevada a $\triangle \mathrm{DCP}$ ref, Exp. Rel. representa EDPC alvo dividido pelo EDPC ref 
Apêndice $\mathrm{H}$

\begin{tabular}{|c|c|c|c|c|c|c|c|c|c|}
\hline \multirow{2}{*}{$\begin{array}{l}\text { Amostras da } \\
\text { região } \\
\text { interplacentomal }\end{array}$} & \multicolumn{3}{|c|}{ Flt-1 } & \multirow[b]{2}{*}{ calibrador } & \multirow[b]{2}{*}{$\begin{array}{l}\text { DCP } \\
\text { alvo }\end{array}$} & \multirow[b]{2}{*}{$\begin{array}{l}\text { DCP } \\
\text { ref }\end{array}$} & \multirow[b]{2}{*}{ EDCPalvo } & \multirow[b]{2}{*}{ EDCPref } & \multirow[b]{2}{*}{ exp rel } \\
\hline & $\mathrm{Ct}$ & $\mathrm{Ct}$ & media & & & & & & \\
\hline 45 D região & 22,81 & 36,47 & 36,59 & 36,53 & 13,73 & 12,99 & $-0,73$ & $-9,81$ & 0,95 \\
\hline 60 D região & 23,83 & 35,18 & 34,86 & 35,02 & 11,19 & 12,99 & 1,80 & $-10,84$ & 1,14 \\
\hline 90 D região & 24,20 & 37,57 & 37,41 & 37,49 & 13,30 & 12,99 & $-0,30$ & $-11,21$ & 0,98 \\
\hline 90 D região & 23,81 & 39,68 & 39,16 & 39,42 & 15,62 & 12,99 & $-2,63$ & $-10,82$ & 0,82 \\
\hline 90 D região & 25,74 & 37,36 & 37,42 & 37,39 & 11,65 & 12,99 & 1,34 & $-12,75$ & 1,10 \\
\hline 90 D região & 25,22 & 36,19 & 36 & 36,63 & 11,41 & 12,99 & 1,59 & $-12,23$ & 1,12 \\
\hline 150 D região & 23,95 & 36,72 & 36,53 & 36,63 & 12,68 & 12,99 & 0,32 & $-10,96$ & 1,02 \\
\hline 150 D região & 22,39 & 33,77 & 33,8 & 33,79 & 11,40 & 12,99 & 1,60 & $-9,40$ & 1,12 \\
\hline 150 D região & 21,10 & 32,3 & 32,29 & 32,30 & 11,20 & 12,99 & 1,80 & $-8,11$ & 1,14 \\
\hline 150 D região & 22,00 & 32,43 & 32,63 & 32,53 & 10,53 & 12,99 & 2,46 & $-9,01$ & 1,20 \\
\hline 210 D região & 24,33 & 37,41 & 37,24 & 37,33 & 13,00 & 12,99 & $-0,01$ & $-11,34$ & 1,00 \\
\hline 210 D região & 21,98 & 31,77 & 32,05 & 31,91 & 9,93 & 12,99 & 3,06 & $-8,99$ & 1,25 \\
\hline 210 D região & 25,10 & 36,38 & 36,67 & 36,53 & 11,43 & 12,99 & 1,57 & $-12,11$ & 1,12 \\
\hline 210 D região & 21,38 & 34,21 & 34,18 & 34,20 & 12,82 & 12,99 & 0,18 & $-8,39$ & 1,01 \\
\hline 270 D região & 24,62 & undet & undet & \#DIV/O! & \#DIV/O! & 12,99 & \#DIV/0! & $-11,63$ & \#DIV/0! \\
\hline
\end{tabular}

Quadro 12 - Representa a corrida de PCR em tempo real com os valores de cada (Ct) para o Flt-1, e a média das duplicatas realizadas para cada amostra. DCP alvo representa o calibrador menos o gene alvo, DCP ref. representa o calibrador menos o controle endógeno, EDCP alvo representa a eficiência elevada a $\triangle \mathrm{DCP}$ alvo, EDPC ref. representa a eficiência elevada a $\triangle \mathrm{DCP}$ ref, Exp. Rel. representa EDPC alvo dividido pelo EDPC ref 
Apêndice I

\begin{tabular}{|c|c|c|c|c|c|c|c|c|c|}
\hline \multirow{2}{*}{$\begin{array}{l}\text { Amostras da } \\
\text { região } \\
\text { interplacentomal }\end{array}$} & \multicolumn{3}{|c|}{ KDR } & \multirow[b]{2}{*}{ calibrador } & \multirow[b]{2}{*}{$\begin{array}{l}\text { DCP } \\
\text { alvo }\end{array}$} & \multirow[b]{2}{*}{$\begin{array}{l}\text { DCP } \\
\text { ref }\end{array}$} & \multirow[b]{2}{*}{ EDCPalvo } & \multirow[b]{2}{*}{ EDCPref } & \multirow[b]{2}{*}{ exp rel } \\
\hline & $\mathrm{Ct}$ & $\mathrm{Ct}$ & media & & & & & & \\
\hline $45 \mathrm{D}$ região & 22,81 & 35,12 & 34,61 & 34,87 & 12,06 & 11,71 & $-23,15$ & $-11,09$ & 0,34 \\
\hline 60 D região & 23,83 & 33,47 & 33,46 & 33,47 & 9,64 & 11,71 & $-21,76$ & $-12,12$ & 0,36 \\
\hline $90 \mathrm{D}$ região & 24,20 & 36,95 & 36,62 & 36,79 & 12,59 & 11,71 & $-25,08$ & $-12,49$ & 0,31 \\
\hline $90 \mathrm{D}$ região & 23,81 & 35,25 & 35,27 & 35,26 & 11,46 & 11,71 & $-23,55$ & $-12,10$ & 0,33 \\
\hline $90 \mathrm{D}$ região & 25,74 & 36,61 & 37,12 & 36,87 & 11,13 & 11,71 & $-25,16$ & $-14,03$ & 0,31 \\
\hline $90 \mathrm{D}$ região & 25,22 & 35,68 & 35,77 & 36,90 & 11,68 & 11,71 & $-25,19$ & $-13,51$ & 0,31 \\
\hline 150 D região & 23,95 & 36,87 & 36,93 & 36,90 & 12,95 & 11,71 & $-25,19$ & $-12,24$ & 0,31 \\
\hline 150 D região & 22,39 & 30,77 & 30,8 & 30,79 & 8,40 & 11,71 & $-19,08$ & $-10,68$ & 0,41 \\
\hline 150 D região & 21,10 & 31,6 & 31,65 & 31,63 & 10,53 & 11,71 & $-19,92$ & $-9,39$ & 0,39 \\
\hline 150 D região & 22,00 & 30,45 & 30,42 & 30,44 & 8,44 & 11,71 & $-18,73$ & $-10,29$ & 0,42 \\
\hline 210 D região & 24,33 & 35 & 34,62 & 34,81 & 10,49 & 11,71 & $-23,10$ & $-12,62$ & 0,34 \\
\hline 210 D região & 21,98 & 32,83 & 32,94 & 32,89 & 10,91 & 11,71 & $-21,18$ & $-10,27$ & 0,37 \\
\hline 210 D região & 25,10 & 37,01 & 36,62 & 36,82 & 11,72 & 11,71 & $-25,11$ & $-13,39$ & 0,31 \\
\hline 210 D região & 21,38 & 34,27 & 34,2 & 34,24 & 12,86 & 11,71 & $-22,53$ & $-9,67$ & 0,35 \\
\hline 270 D região & 24,62 & 37,37 & 37,92 & 37,65 & 13,03 & 11,71 & $-25,94$ & $-12,91$ & 0,30 \\
\hline
\end{tabular}

Quadro 13 - Representa a corrida de PCR em tempo real com os valores de cada (Ct) para o KDR, e a média das duplicatas realizadas para cada amostra. . DCP alvo representa o calibrador menos o gene alvo, DCP ref. representa o calibrador menos o controle endógeno, EDCP alvo representa a eficiência elevada a $\triangle \mathrm{DCP}$ alvo, EDPC ref. representa a eficiência elevada a $\triangle \mathrm{DCP}$ ref, Exp. Rel. representa EDPC alvo dividido pelo EDPC ref 
Apêndice J

\begin{tabular}{|c|c|c|c|c|c|c|c|c|c|c|c|}
\hline \multirow{2}{*}{$\begin{array}{l}\text { Amostras de } \\
\text { corpo lúteo } \\
\text { gestacional }\end{array}$} & \multicolumn{3}{|c|}{ GAPDH } & \multicolumn{3}{|c|}{ VEGF } & \multirow[b]{2}{*}{$\begin{array}{l}\text { DCP } \\
\text { alvo }\end{array}$} & \multirow[b]{2}{*}{ DCP ref } & \multirow[b]{2}{*}{ EDCPalvo } & \multirow[b]{2}{*}{ EDCPref } & \multirow[b]{2}{*}{ exp rel } \\
\hline & $\mathrm{Ct}$ & $\mathrm{Ct}$ & media & $\mathrm{Ct}$ & $\mathrm{Ct}$ & media & & & & & \\
\hline $45 \mathrm{D} \mathrm{CL}$ & 25,42 & 25,14 & 25,28 & 30,03 & 29,94 & 29,99 & $-27,91$ & $-21,53$ & 6,67 & 6,23 & 1,07 \\
\hline $60 \mathrm{D} C L$ & 23,91 & 23,96 & 23,94 & 28,47 & 28,48 & 28,48 & $-26,41$ & $-20,19$ & 6,02 & 5,56 & 1,08 \\
\hline $90 \mathrm{D} C L$ & 28,08 & 28,04 & 28,06 & 30,19 & 30,27 & 30,23 & $-28,34$ & $-24,31$ & 6,87 & 7,89 & 0,87 \\
\hline $90 \mathrm{D} \mathrm{CL}$ & 26,13 & 26,31 & 26,22 & 31,2 & 31,45 & 31,33 & $-29,22$ & $-22,47$ & 7,29 & 6,75 & 1,08 \\
\hline $90 \mathrm{D} C L$ & 26,91 & 26,87 & 26,89 & 30,68 & 30,86 & 30,77 & $-28,76$ & $-23,14$ & 7,06 & 7,14 & 0,99 \\
\hline $90 \mathrm{D} C L$ & 26,46 & 26,65 & 26,56 & 30,47 & 30,36 & 30,42 & $-28,41$ & $-22,81$ & 6,90 & 6,94 & 0,99 \\
\hline $150 \mathrm{D} \mathrm{CL}$ & 22,75 & 22,82 & 22,79 & 27,39 & 27,38 & 27,39 & $-25,32$ & $-19,04$ & 5,59 & 5,04 & 1,11 \\
\hline $150 \mathrm{D} C L$ & 24,18 & 24,28 & 24,23 & 27,69 & 27,75 & 27,72 & $-25,74$ & $-20,48$ & 5,75 & 5,70 & 1,01 \\
\hline $150 \mathrm{D} C L$ & 27,33 & 27,27 & 27,30 & 31,13 & 31,05 & 31,09 & $-29,09$ & $-23,55$ & 7,22 & 7,40 & 0,98 \\
\hline $150 \mathrm{D} C L$ & 26,21 & 26,31 & 26,26 & 31,1 & 30,97 & 31,04 & $-28,95$ & $-22,51$ & 7,16 & 6,77 & 1,06 \\
\hline $210 \mathrm{D} C L$ & 24,39 & 24,34 & 24,37 & 29,68 & 29,53 & 29,61 & $-27,48$ & $-20,62$ & 6,48 & 5,77 & 1,12 \\
\hline $210 \mathrm{D} C L$ & 25,27 & 25,21 & 25,24 & 32,2 & 32,16 & 32,18 & $-29,90$ & $-21,49$ & 7,64 & 6,21 & 1,23 \\
\hline 210 D CL & 24,16 & 24,36 & 24,26 & 29,76 & 29,7 & 29,73 & $-27,59$ & $-20,51$ & 6,52 & 5,71 & 1,14 \\
\hline $210 \mathrm{D} C L$ & 23,46 & 23,55 & 23,51 & 30,06 & 29,66 & 29,86 & $-27,64$ & $-19,76$ & 6,55 & 5,36 & 1,22 \\
\hline
\end{tabular}

Quadro 14 - Representa a corrida de PCR em tempo real com os valores de cada (Ct) para o GADPH e VEGF, e a média das duplicatas realizadas para cada amostra. DCP alvo representa o calibrador menos o gene alvo, DCP ref. representa o calibrador menos o controle endógeno, EDCP alvo representa a eficiência elevada a $\triangle \mathrm{DCP}$ alvo, EDPC ref. representa a eficiência elevada a $\triangle \mathrm{DCP}$ ref, Exp. Rel. representa EDPC alvo dividido pelo EDPC ref 


\section{Apêndice K}

\begin{tabular}{|c|c|c|c|c|c|c|c|c|c|}
\hline \multirow{2}{*}{$\begin{array}{l}\text { Amostras de } \\
\text { corpo lúteo } \\
\text { gestacional }\end{array}$} & \multicolumn{3}{|c|}{ Flt-1 } & & & & \multirow[b]{2}{*}{ EDCPalvo } & \multirow[b]{2}{*}{ EDCPref } & \multirow[b]{2}{*}{ exp rel } \\
\hline & $\mathrm{Ct}$ & $\mathrm{Ct}$ & media & calibrador & \begin{tabular}{|l|} 
DCP \\
alvo
\end{tabular} & \begin{tabular}{|l} 
DCP \\
ref
\end{tabular} & & & \\
\hline $45 \mathrm{DCL}$ & 34,62 & 34,57 & 34,60 & 3,75 & $-30,85$ & $-21,53$ & 0,10 & 6,23 & 0,02 \\
\hline $60 \mathrm{DCL}$ & 32,04 & 32,05 & 32,05 & 3,75 & $-28,30$ & $-20,19$ & 0,13 & 5,56 & 0,02 \\
\hline $90 \mathrm{DCL}$ & 34 & 34 & 34,00 & 3,75 & $-30,25$ & $-24,31$ & 0,11 & 7,89 & 0,01 \\
\hline $90 \mathrm{DCL}$ & 36,85 & 37,19 & 37,02 & 3,75 & $-33,27$ & $-22,47$ & 0,09 & 6,75 & 0,01 \\
\hline $90 \mathrm{DCL}$ & 34,79 & 35,14 & 34,97 & 3,75 & $-31,22$ & $-23,14$ & 0,10 & 7,14 & 0,01 \\
\hline $90 \mathrm{DCL}$ & undet & undet & & 3,75 & 3,75 & $-22,81$ & 1,32 & 6,94 & 0,19 \\
\hline $150 \mathrm{DCL}$ & 32,69 & 32,69 & 32,69 & 3,75 & $-28,94$ & $-19,04$ & 0,12 & 5,04 & 0,02 \\
\hline $150 \mathrm{DCL}$ & 31,33 & 31,43 & 31,38 & 3,75 & $-27,63$ & $-20,48$ & 0,13 & 5,70 & 0,02 \\
\hline $150 \mathrm{DCL}$ & 35,8 & 36,18 & 35,99 & 3,75 & $-32,24$ & $-23,55$ & 0,09 & 7,40 & 0,01 \\
\hline $150 \mathrm{DCL}$ & 35,07 & 35,09 & 35,08 & 3,75 & $-31,33$ & $-22,51$ & 0,10 & 6,77 & 0,01 \\
\hline $210 \mathrm{DCL}$ & 33,58 & 33,52 & 33,55 & 3,75 & $-29,80$ & $-20,62$ & 0,11 & 5,77 & 0,02 \\
\hline $210 \mathrm{DCL}$ & 37,28 & 37 & 37,14 & 3,75 & $-33,39$ & $-21,49$ & 0,09 & 6,21 & 0,01 \\
\hline $210 \mathrm{DCL}$ & 33,85 & 33,6 & 33,73 & 3,75 & $-29,98$ & $-20,51$ & 0,11 & 5,71 & 0,02 \\
\hline $210 \mathrm{DCL}$ & 34,93 & 34,9 & 34,92 & 3,75 & $-31,17$ & $-19,76$ & 0,10 & 5,36 & 0,02 \\
\hline
\end{tabular}

Quadro 15 - Representa a corrida de PCR em tempo real com os valores de cada (Ct) para o Flt-1, e a média das duplicatas realizadas para cada amostra. DCP alvo representa o calibrador menos o gene alvo, DCP ref. representa o calibrador menos o controle endógeno, EDCP alvo representa a eficiência elevada a $\triangle \mathrm{DCP}$ alvo, EDPC ref. representa a eficiência elevada a $\triangle \mathrm{DCP}$ ref, Exp. Rel. representa EDPC alvo dividido EDPC ref 
Apêndice L

\begin{tabular}{|c|c|c|c|c|c|c|c|c|c|}
\hline \multirow{2}{*}{$\begin{array}{l}\text { Amostras de } \\
\text { corpo lúteo } \\
\text { gestacional }\end{array}$} & \multicolumn{3}{|c|}{ KDR } & \multirow[b]{2}{*}{ calibrador } & \multirow[b]{2}{*}{$\begin{array}{l}\text { DCP } \\
\text { alvo }\end{array}$} & \multirow[b]{2}{*}{\begin{tabular}{|l|} 
DCP \\
ref
\end{tabular}} & \multirow[b]{2}{*}{ EDCPalvo } & \multirow[b]{2}{*}{ EDCPref } & \multirow[b]{2}{*}{ exp rel } \\
\hline & $\mathrm{Ct}$ & $\mathrm{Ct}$ & media & & & & & & \\
\hline $45 \mathrm{DCL}$ & 34,57 & 35 & 34,79 & 3,75 & $-31,04$ & $-21,53$ & 0,24 & 6,23 & 0,04 \\
\hline $60 \mathrm{DCL}$ & 32,42 & 32,39 & 32,41 & 3,75 & $-28,66$ & $-20,19$ & 0,26 & 5,56 & 0,05 \\
\hline $90 \mathrm{DCL}$ & 33,43 & 33,87 & 33,65 & 3,75 & $-29,90$ & $-24,31$ & 0,25 & 7,89 & 0,03 \\
\hline $90 \mathrm{DCL}$ & 35,44 & 35,74 & 35,59 & 3,75 & $-31,84$ & $-22,47$ & 0,23 & 6,75 & 0,03 \\
\hline $90 \mathrm{DCL}$ & 35,91 & 35,83 & 35,87 & 3,75 & $-32,12$ & $-23,14$ & 0,22 & 7,14 & 0,03 \\
\hline $90 \mathrm{DCL}$ & 34,49 & 34,48 & 34,49 & 3,75 & $-30,74$ & $-22,81$ & 0,24 & 6,94 & 0,03 \\
\hline $150 \mathrm{DCL}$ & 31,17 & 31,15 & 31,16 & 3,75 & $-27,41$ & $-19,04$ & 0,28 & 5,04 & 0,06 \\
\hline $150 \mathrm{DCL}$ & 31,64 & 31,48 & 31,56 & 3,75 & $-27,81$ & $-20,48$ & 0,27 & 5,70 & 0,05 \\
\hline $150 \mathrm{DCL}$ & 34,85 & 35,2 & 35,03 & 3,75 & $-31,28$ & $-23,55$ & 0,23 & 7,40 & 0,03 \\
\hline $150 \mathrm{DCL}$ & 33,26 & 33,27 & 33,27 & 3,75 & $-29,52$ & $-22,51$ & 0,25 & 6,77 & 0,04 \\
\hline $210 \mathrm{DCL}$ & 32,15 & 32,09 & 32,12 & 3,75 & $-28,37$ & $-20,62$ & 0,27 & 5,77 & 0,05 \\
\hline $210 \mathrm{DCL}$ & 34,98 & 35,49 & 35,24 & 3,75 & $-31,49$ & $-21,49$ & 0,23 & 6,21 & 0,04 \\
\hline $210 \mathrm{DCL}$ & 32,36 & 32,36 & 32,36 & 3,75 & $-28,61$ & $-20,51$ & 0,26 & 5,71 & 0,05 \\
\hline $210 \mathrm{DCL}$ & 32,32 & 32,59 & 32,46 & 3,75 & $-28,71$ & $-19,76$ & 0,26 & 5,36 & 0,05 \\
\hline
\end{tabular}

Quadro 16 -Representa a corrida de PCR em tempo real com os valores de cada (Ct) para o KDR, e a média das duplicatas realizadas para cada amostra. DCP alvo representa o calibrador menos o gene alvo, DCP ref. representa o calibrador menos o controle endógeno, EDCP alvo representa a eficiência elevada a $\triangle \mathrm{DCP}$ alvo, EDPC ref. representa a eficiência elevada a $\triangle$ DCP ref, Exp. Rel. representa EDPC alvo dividido pelo EDPC ref 